Cooperative transport and selective extraction of sulfates by squaramide based ion pair receptor - a case of adaptable

\title{
selectivity
}

by

Marta Zaleskaya, Marcin Karbarz, Marcin Wilczek, Łukasz Dobrzycki, Jan Romański*

*Faculty of Chemistry, University of Warsaw, Pasteura 1, PL 02-093 Warsaw, Poland *jarom@chem.uw.edu.pl

Table of Contents

1. General information $\quad$ S2

2. NMR spectra $\quad$ S3

3. UV-vis titration experiments (Dilution studies, Binding isotherms) S6

4. NMR Titration S29

5. Extraction experiments - UV-vis $\quad$ S34

6. Extraction experiments - Atomic Emission Spectroscopy S35

7. Extraction experiments - Ion Chromatography S36

8. Dynamic Light Scattering (DLS) $\mathbf{S 4 0}$

9. DOSY experiments $\quad$ S41

$\begin{array}{ll}\text { 10. U-tube transport studies } & \text { S47 }\end{array}$

11. Crystal data $\quad$ S50

12. References $\quad$ S59 


\section{General information}

Unless specifically indicated, all other chemicals and reagents used in this study were purchased from commercial sources and used as received. If necessary purification of products was performed using column chromatography on silica gel (Merck Kieselgel 60, 230-400 mesh) with mixtures of chloroform/methanol. Thin-layer chromatography (TLC) was performed on silica gel plates (Merck Kieselgel 60 F254).

${ }^{1} \mathrm{H}$ and ${ }^{13} \mathrm{C}$ NMR spectra used in the characterization of products were recorded on Bruker 300 spectrometer using a residual protonated solvent as internal standard. DOSY experiments were conducted at $298 \mathrm{~K}$ on Varian VNMRS $600 \mathrm{MHz}$ instruments with a residual solvent signal as an internal standard.

Mass spectra were measured on Quattro LC Micromass or Shimadzu LCMS-IT-TOF unit.

UV-vis analyses were performed using Thermo Spectronic Unicam UV500 Spectrophotometer. Atomic emission measurements were performed using Perkin Elmer AAnalyst 300 spectometer.

Dynamic Light Scattering analyses were performed using a Malvern Zetasizer instrument (Nano ZS, UK) equipped with a 4-mW helium-neon laser of light wavelength $632.8 \mathrm{~nm}$ was used. The scattering angle was set to $170^{\circ}$ and at $25^{\circ} \mathrm{C}$. The hydrodynamic diameter distributions were obtained by volume using the software package of the apparatus. Each curve represents the average of 3 measurements (16 runs each). Prior to analysis, all solutions were filtered and degassed. 


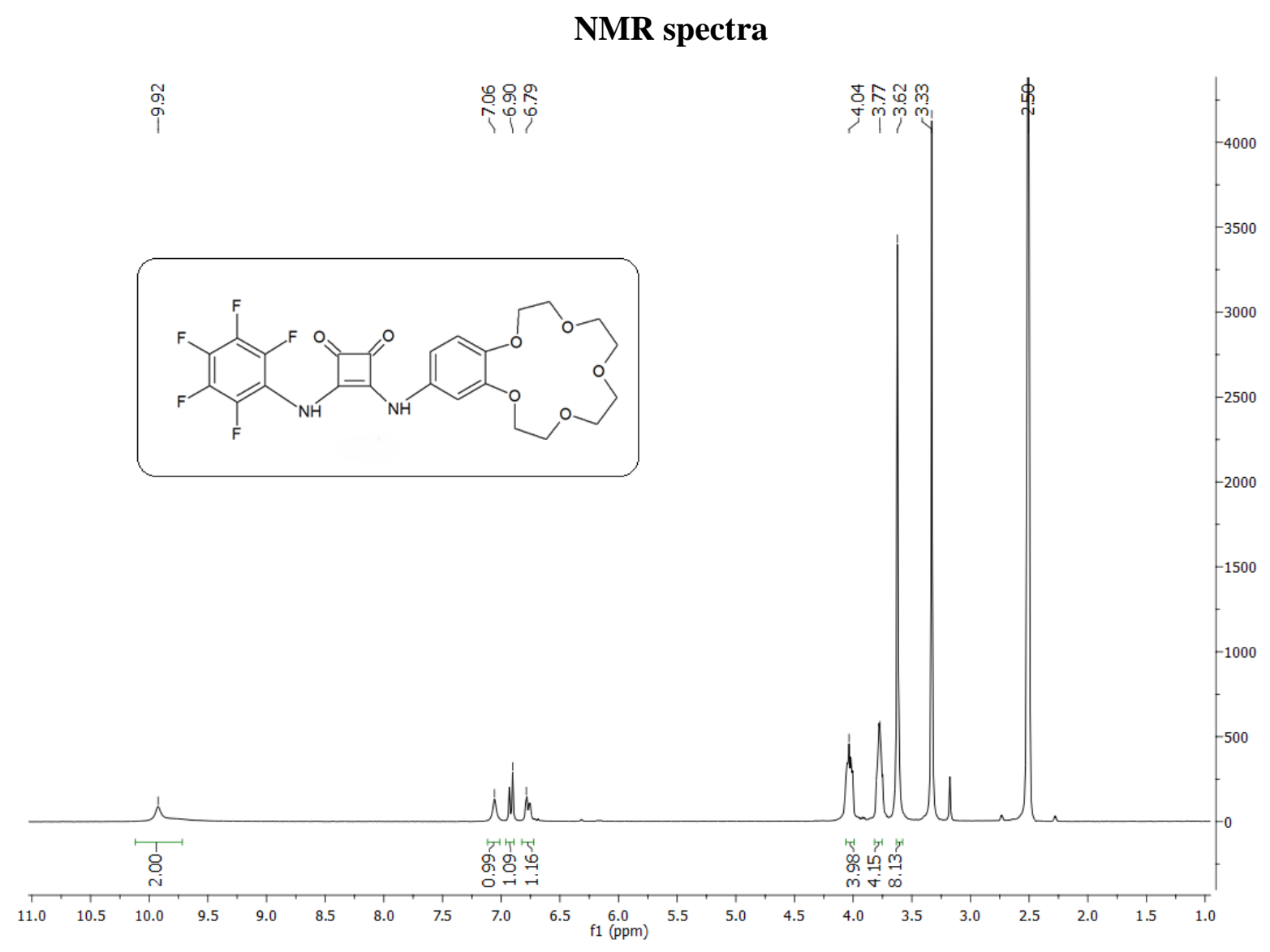

Fig. S1. ${ }^{1} \mathrm{H}$ NMR spectrum of Receptor 1 in DMSO-d6.

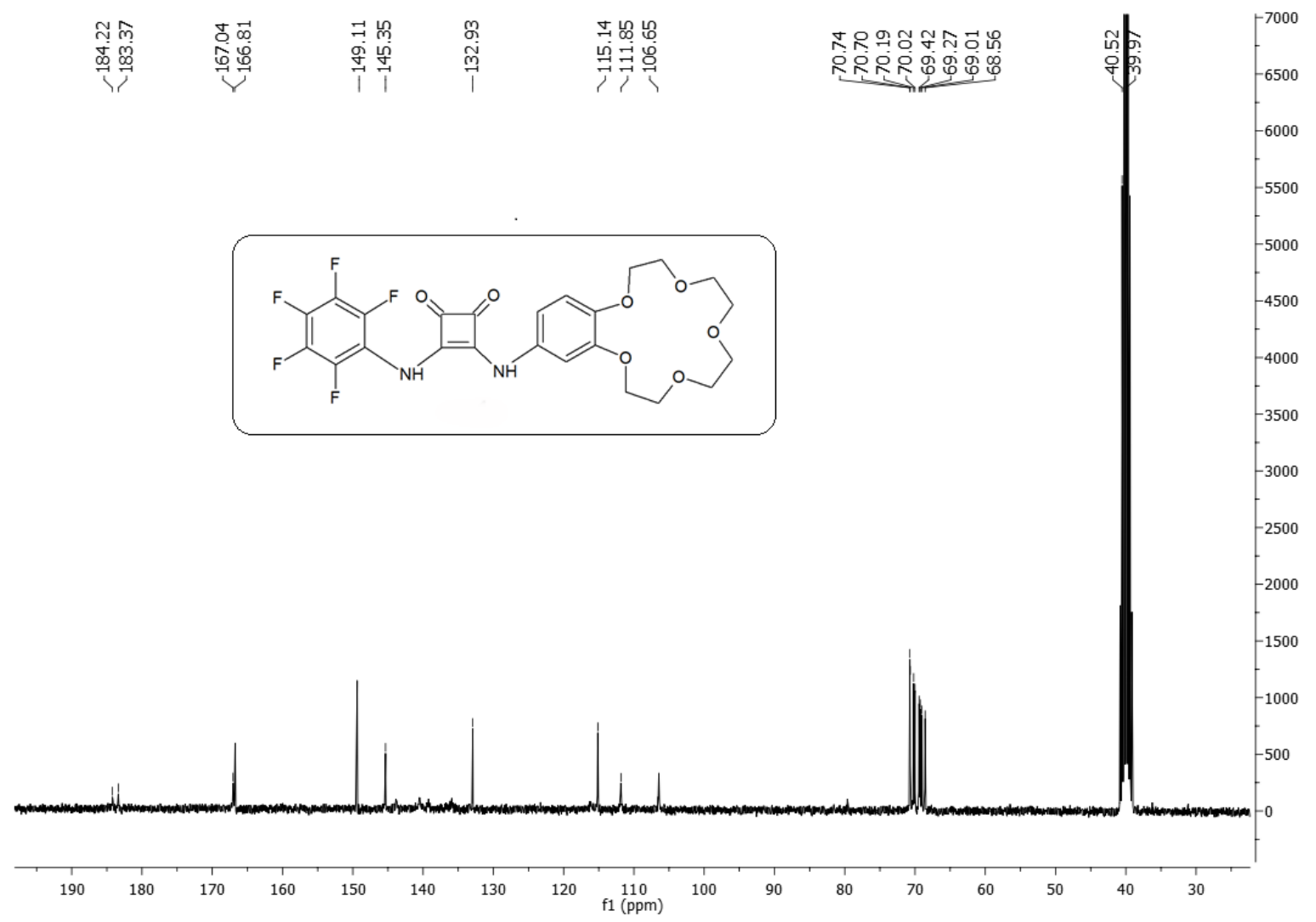

Fig. S2. ${ }^{13} \mathrm{C}$ NMR spectrum of Receptor $\mathbf{1}$ in DMSO-d 6 . 


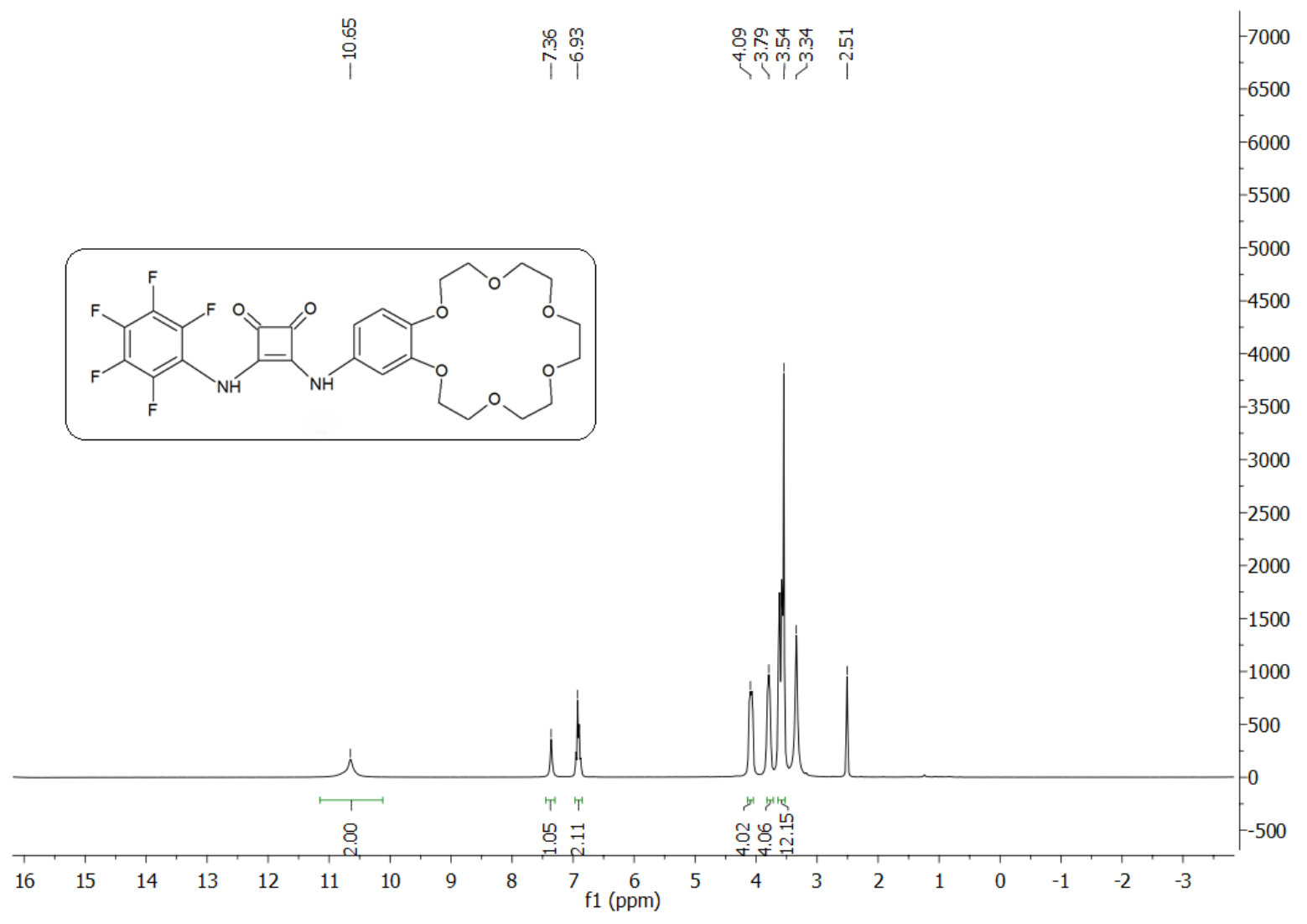

Fig. S3. ${ }^{1} \mathrm{H}$ NMR spectrum of Receptor 2 in DMSO-d 6 .

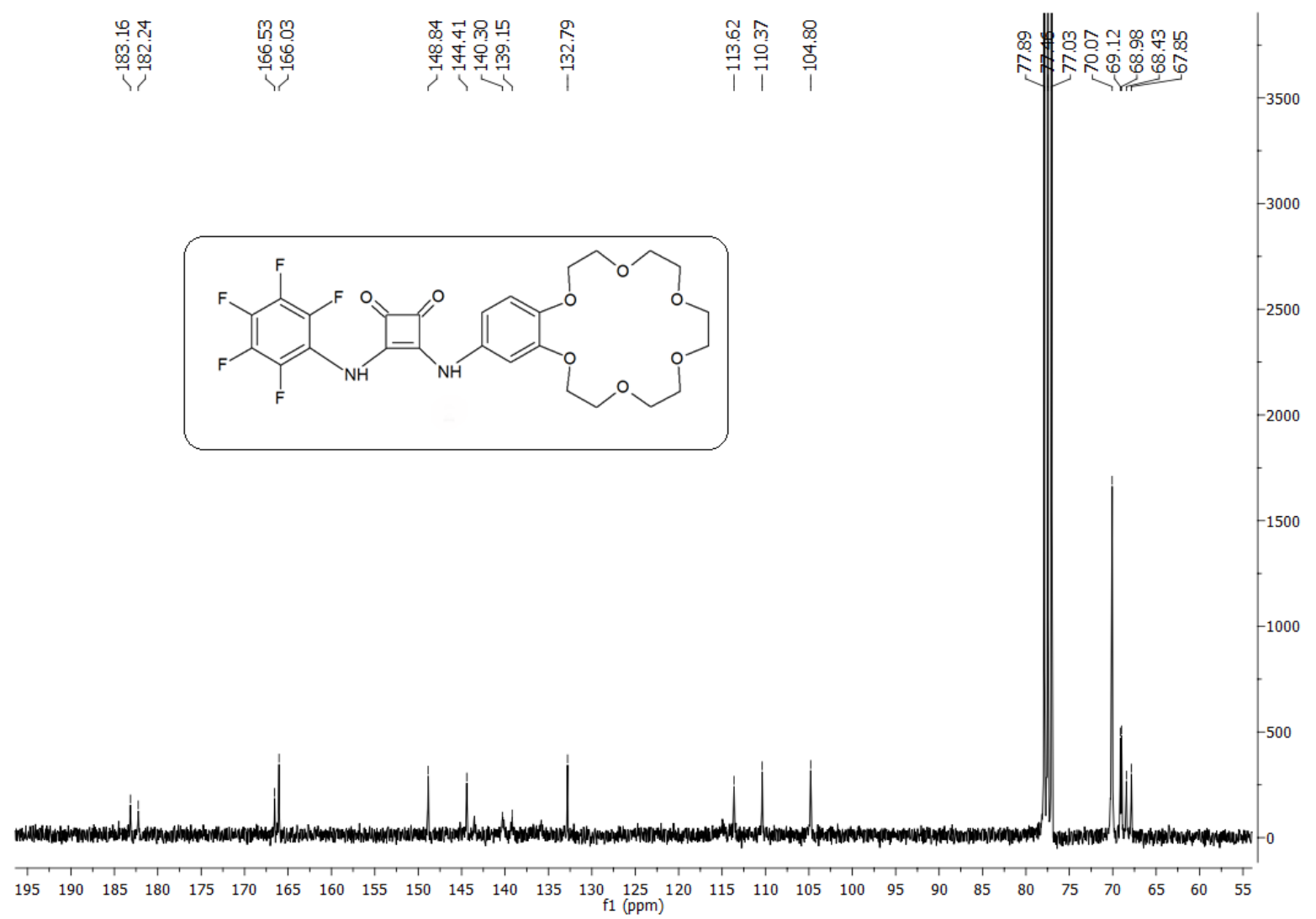

Fig. S4. ${ }^{13} \mathrm{C}$ NMR spectrum of Receptor 2 in $\mathrm{CDCl}_{3}$. 


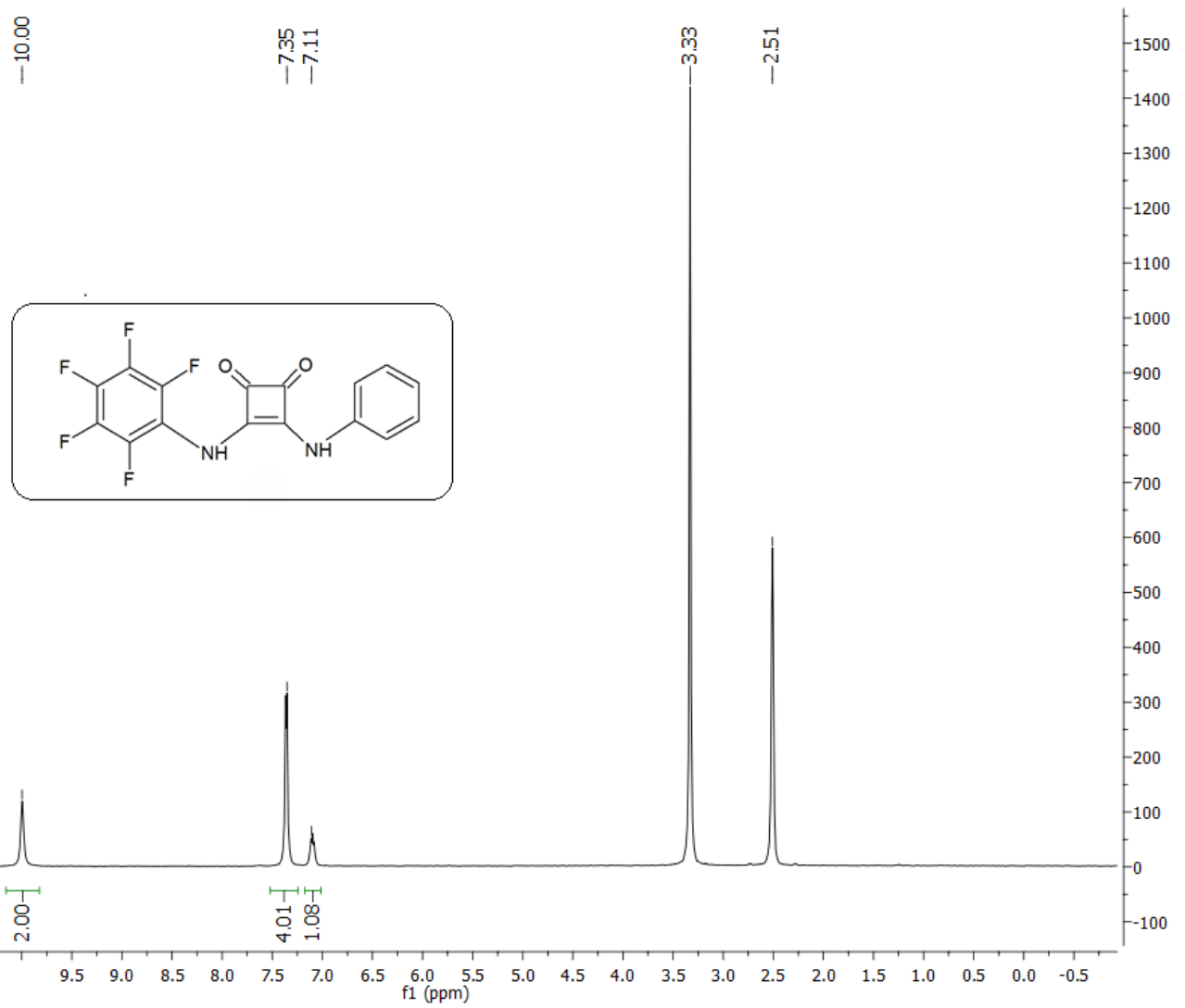

Fig. S5. ${ }^{1} \mathrm{H}$ NMR spectrum of Receptor 3 in DMSO-d 6 .

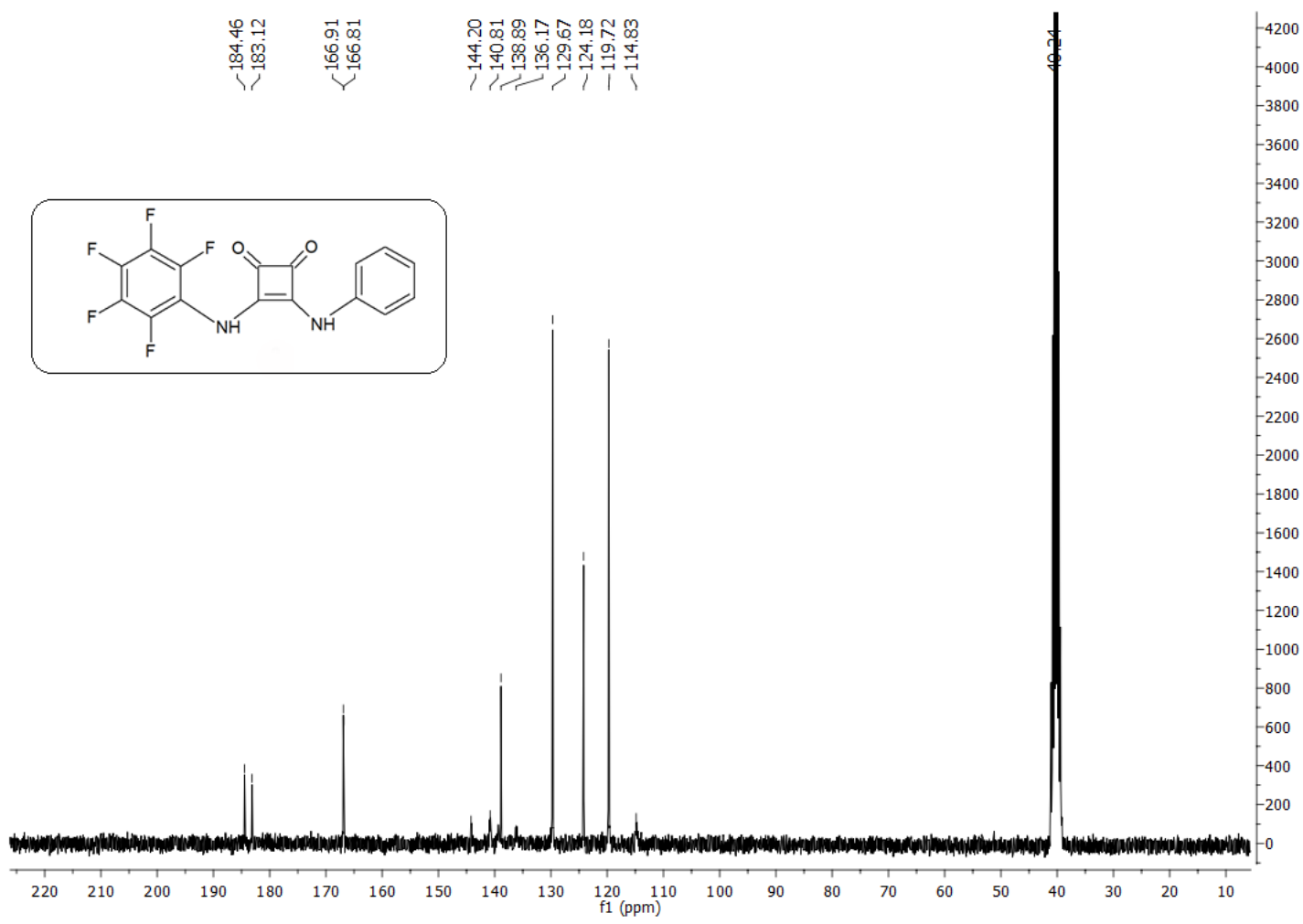

Fig. S6. ${ }^{13} \mathrm{C}$ NMR spectrum of Receptor 3 in DMSO-d 6 . 


\section{UV-vis titration experiments}

General procedure. UV-vis titration experiments were performed on a Thermo Spectronic Unicam UV 500 spectrophotometer in $\mathrm{CH}_{3} \mathrm{CN}$ solution at 298K. To $10 \mathrm{~mm}$ cuvette was added $2.5 \mathrm{~mL}$ of freshly prepared (receptor $\mathbf{1}-2.85 \times 10^{-5} \mathrm{M}$, receptor $2-2.63 \times 10^{-5} \mathrm{M}$, receptor 3 $2.16 \times 10^{-5} \mathrm{M}$ ) solution of studied receptor and in case of ion pair binding studies $1 \mathrm{~mol}$ equivalent of cation $\left(\mathrm{KPF}_{6}\right.$ or $\left.\mathrm{NaClO}_{4}\right)$ was added prior titrations. Small aliquots of ca. $1.5 \times 10^{-}$ ${ }^{3} \mathrm{M}$ TBAX solution containing receptor $\mathbf{1}$, receptor $\mathbf{2}$ or receptor $\mathbf{3}$ at the same concentration as in cuvette, were added and a spectrum was acquired after each addition. The resulting titration data were analyzed using BindFit (v0.5) package, available online at http://supramolecular.org.

\section{Dilution studies}

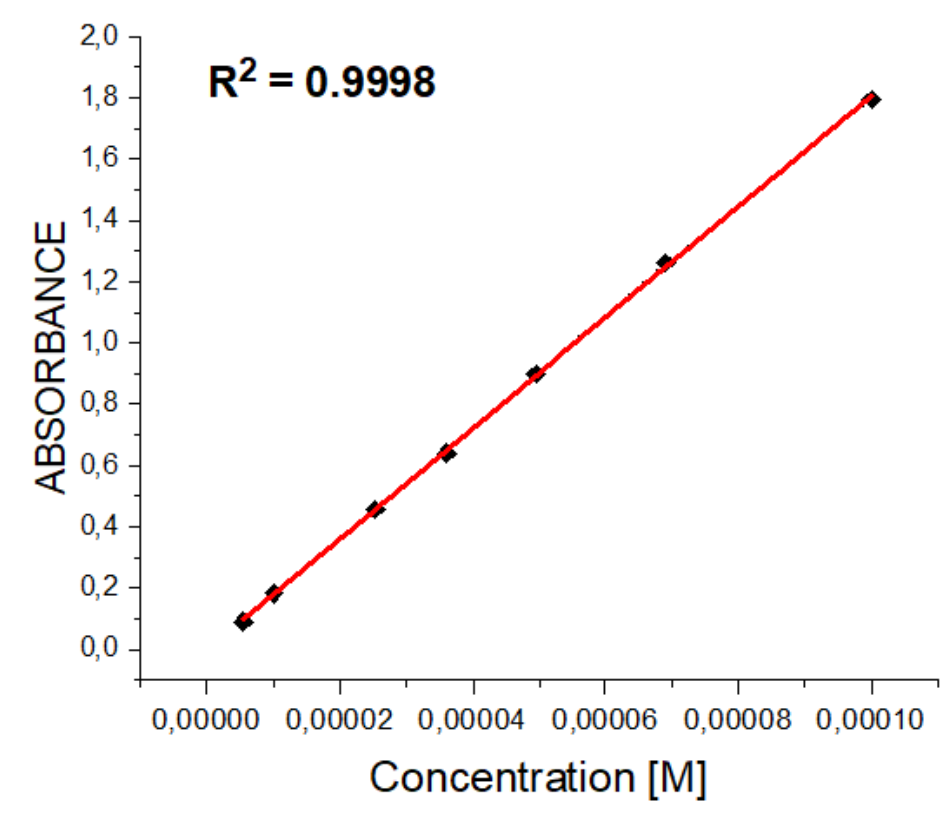

Fig. S7. Dilution curve of receptor 2. 


\section{Binding isotherms}
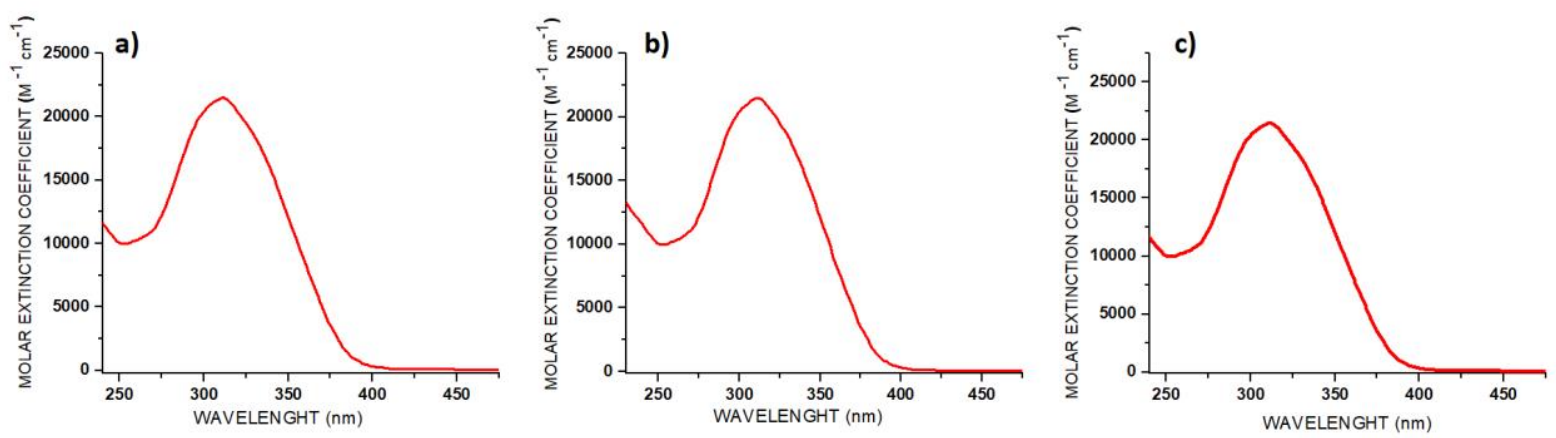

Fig. S8. Spectra of molar extinction coefficients for: (a) receptor 1; (b) receptor 2; (c) receptor 3.
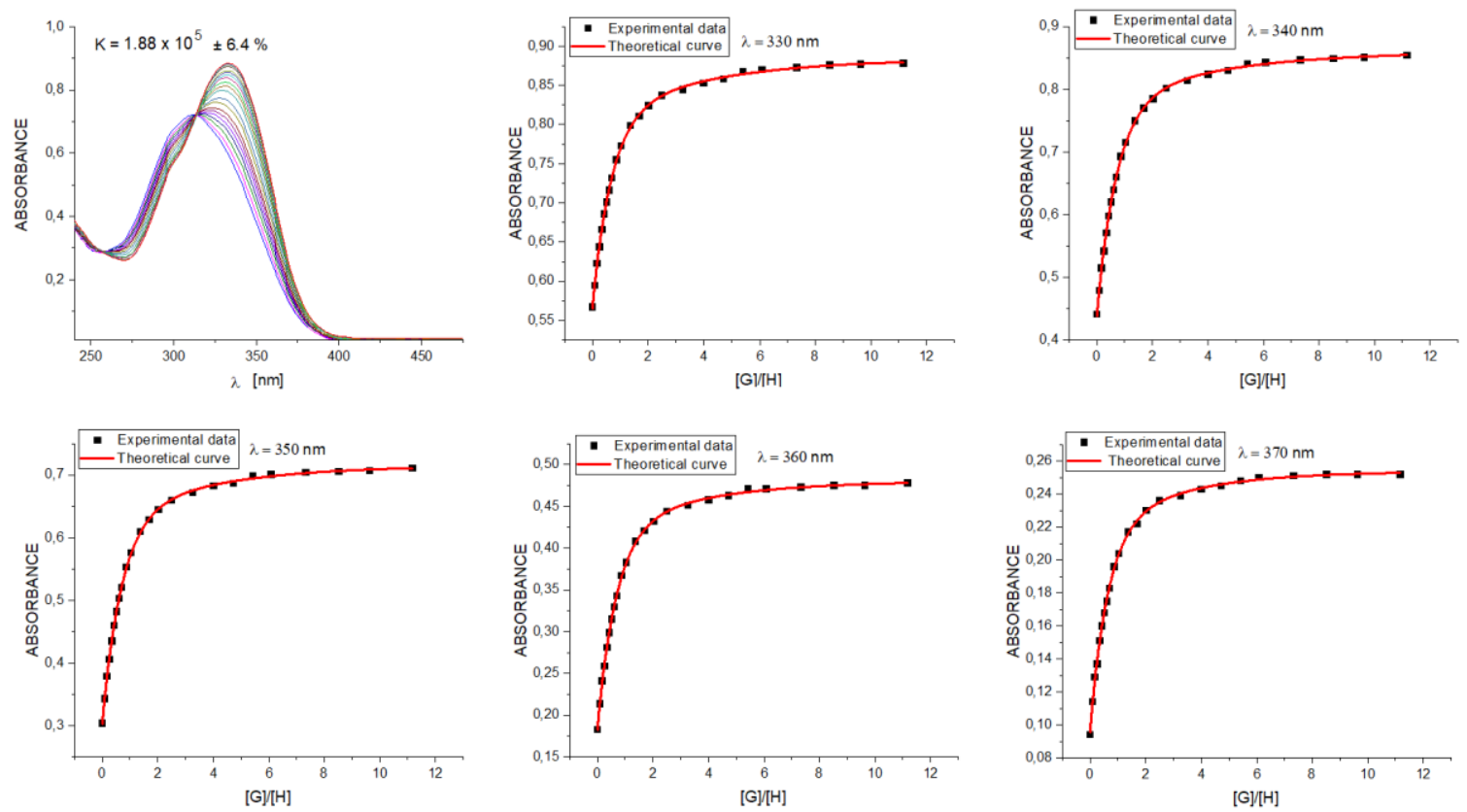

Fig. S9. UV-vis titration of receptor 1 with $\mathrm{TBACl}$ in $\mathrm{CH}_{3} \mathrm{CN}$ and selected binding isotherms. 

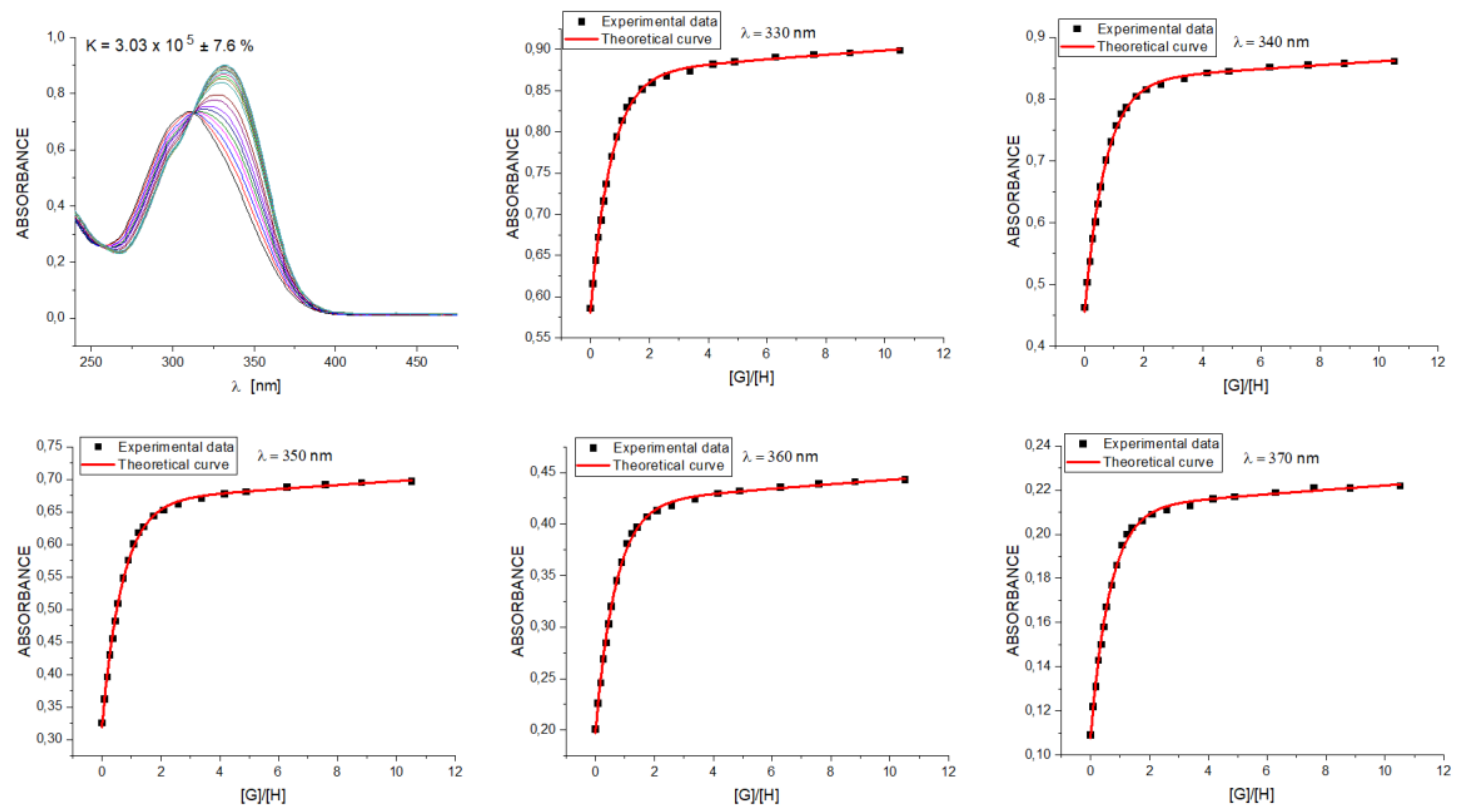

Fig. S10. UV-vis titration of receptor 1 with TBACl in the presence of 1 equivalent of $\mathrm{NaClO}_{4}$ in $\mathrm{CH}_{3} \mathrm{CN}$ and selected binding isotherms.
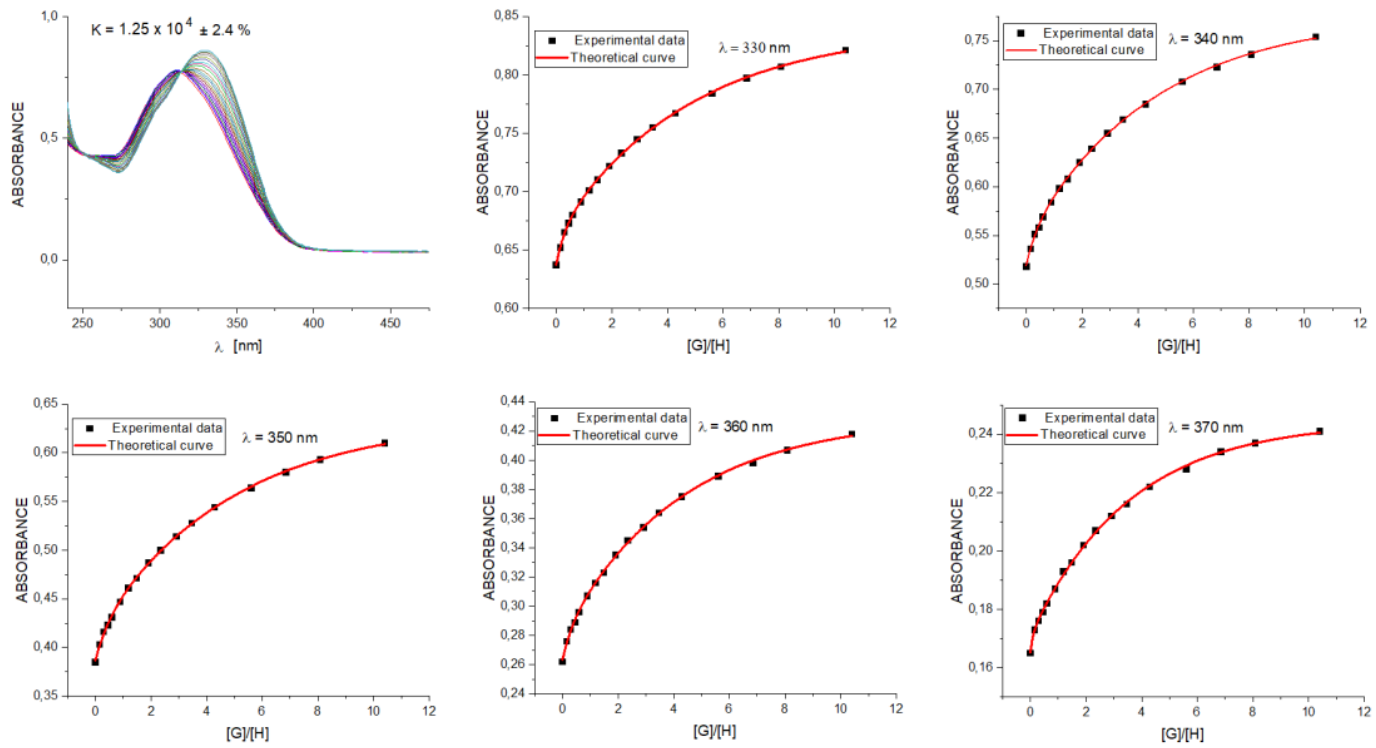

Fig. S11. UV-vis titration of receptor 1 with $\mathrm{TBABr}$ in $\mathrm{CH}_{3} \mathrm{CN}$ and selected binding isotherms. 

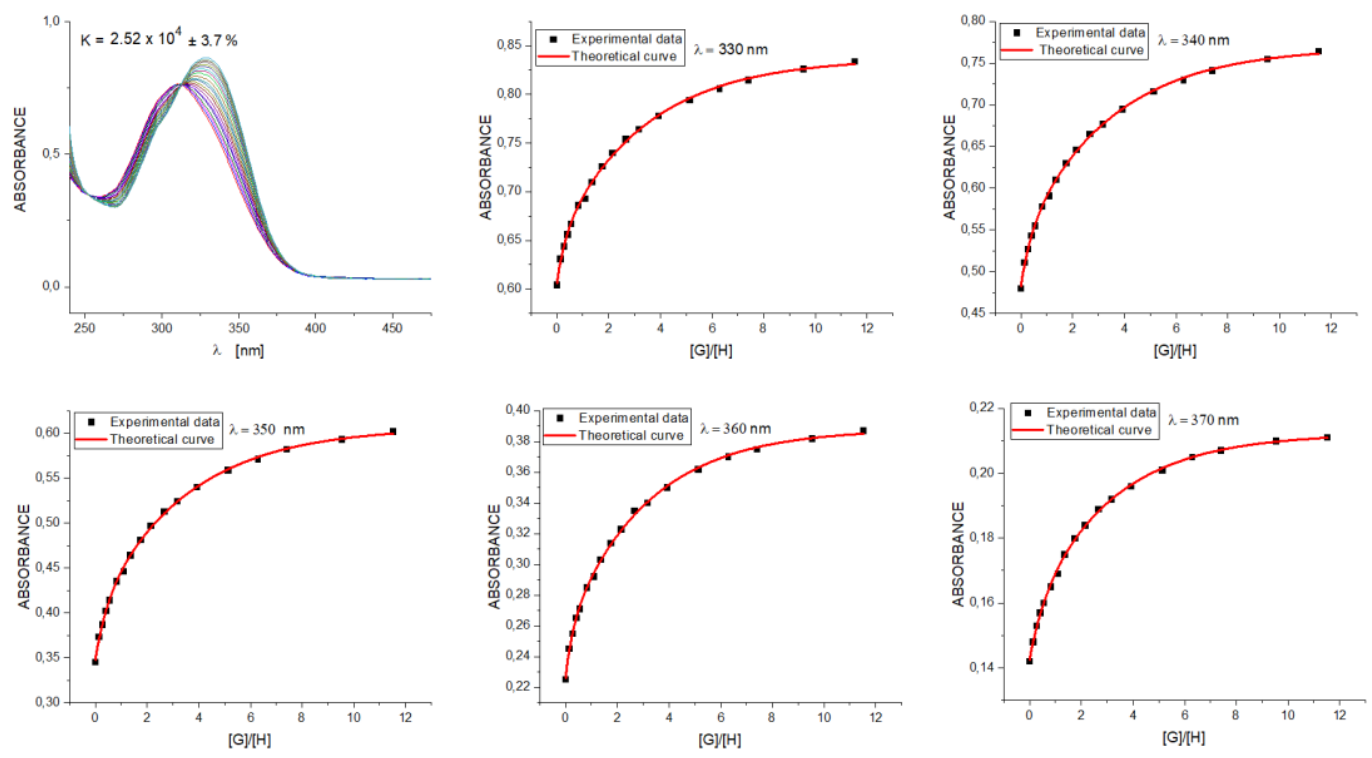

Fig. S12. UV-vis titration of receptor 1 with $\mathrm{TBABr}$ in the presence of 1 equivalent of $\mathrm{NaClO}_{4}$ in $\mathrm{CH}_{3} \mathrm{CN}$ and selected binding isotherms.
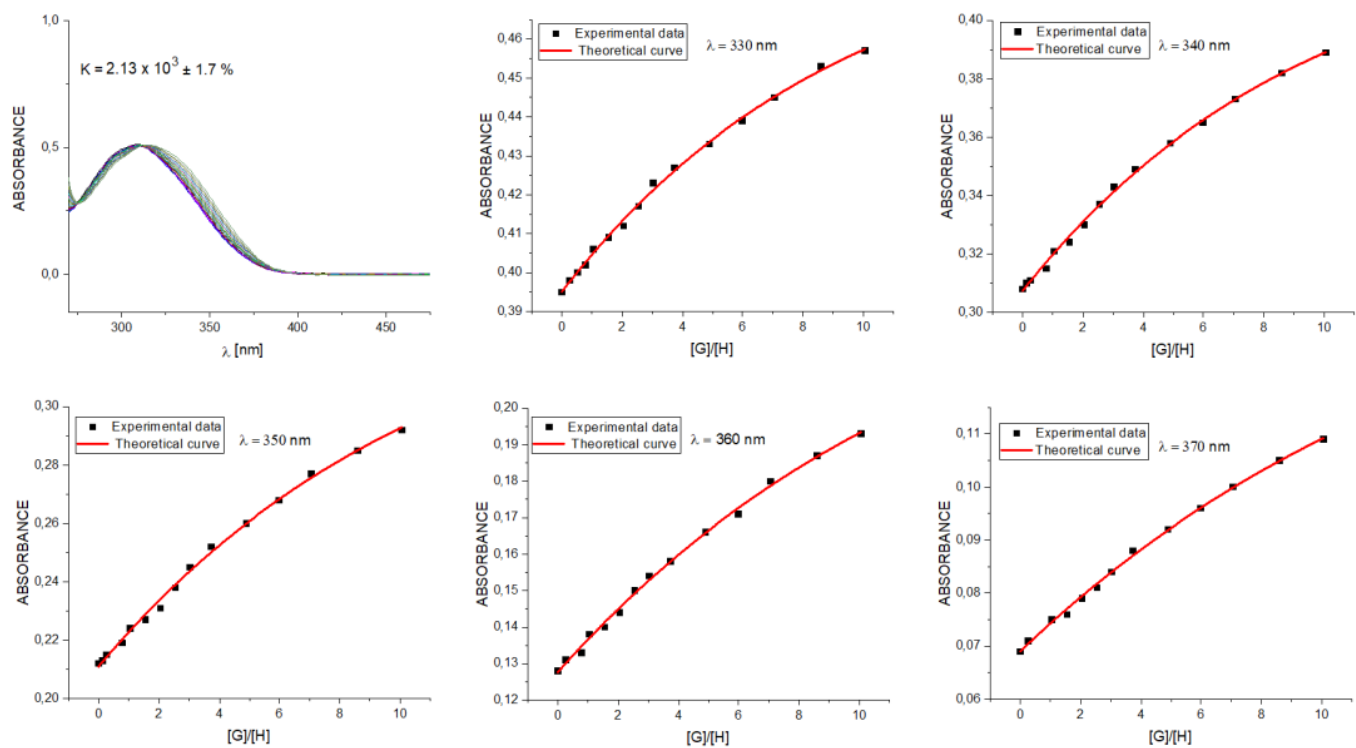

Fig. S13. UV-vis titration of receptor 1 with TBAI in $\mathrm{CH}_{3} \mathrm{CN}$ and selected binding isotherms. 

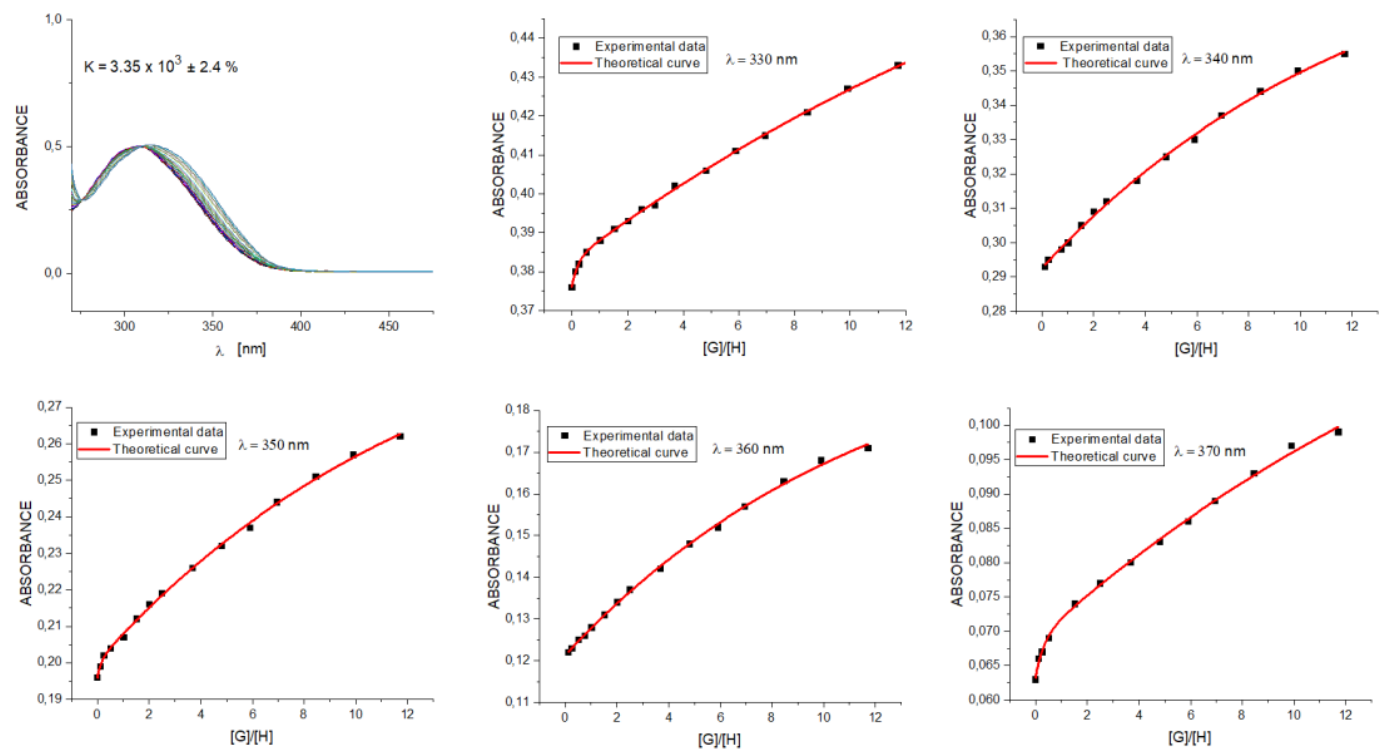

Fig. S14. UV-vis titration of receptor 1 with TBAI in the presence of 1 equivalent of $\mathrm{NaClO}_{4}$ in $\mathrm{CH}_{3} \mathrm{CN}$ and selected binding isotherms.
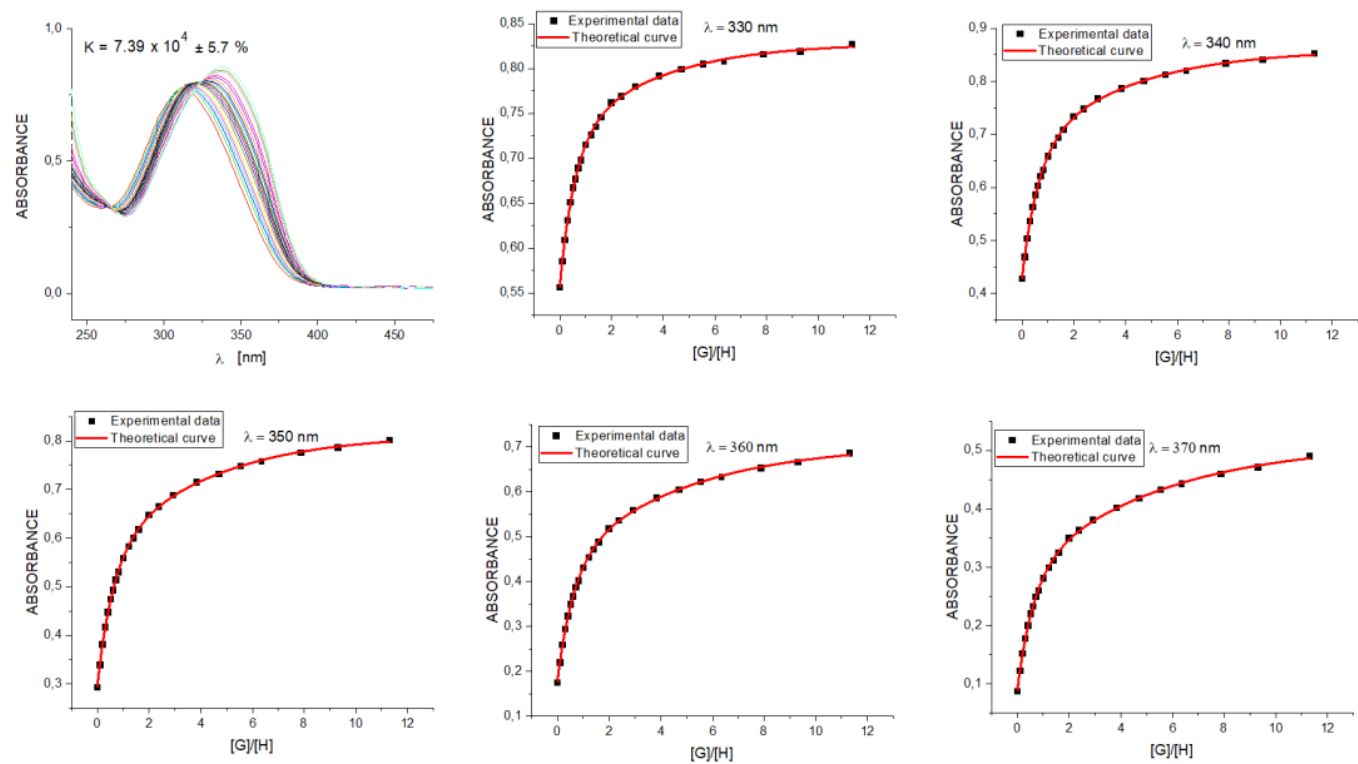

Fig. S15. UV-vis titration of receptor 1 with $\mathrm{TBANO}_{2}$ in $\mathrm{CH}_{3} \mathrm{CN}$ and selected binding isotherms. 

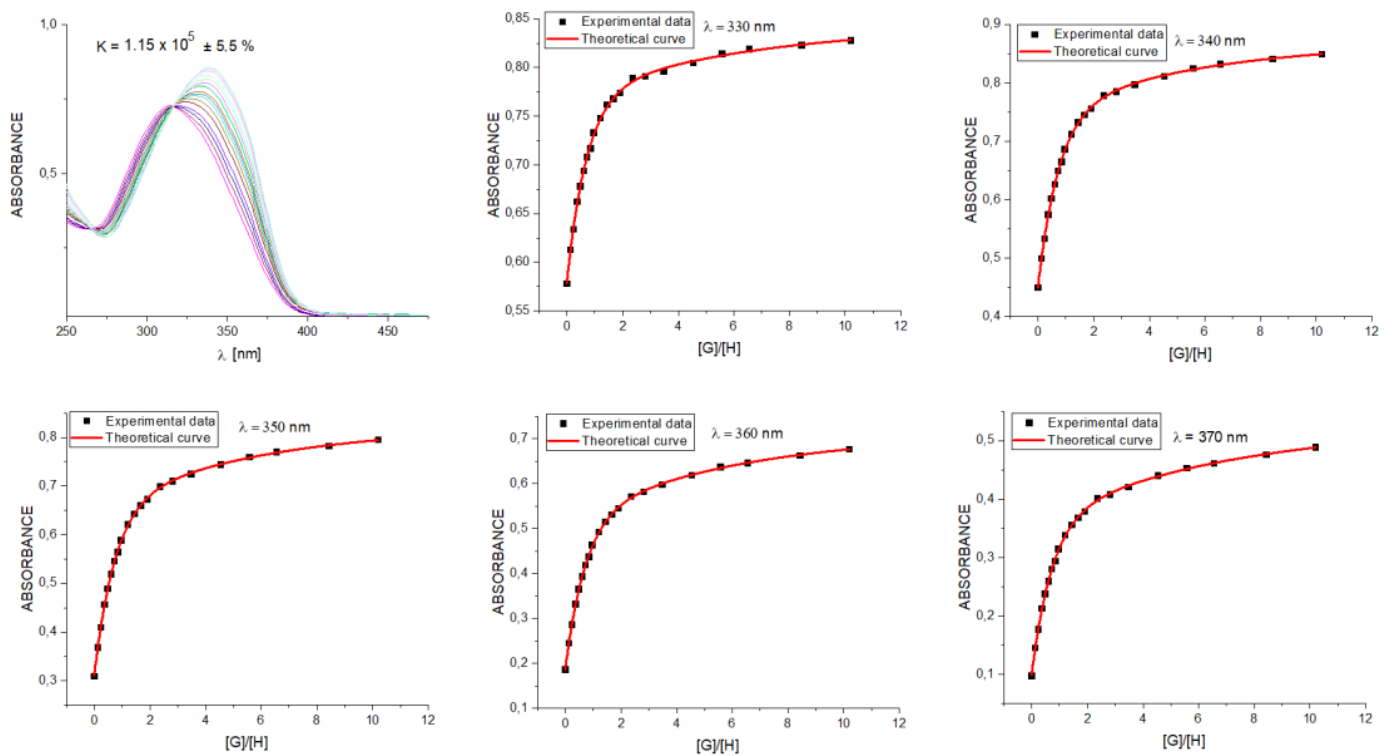

Fig. S16. UV-vis titration of receptor 1 with $\mathrm{TBANO}_{2}$ in the presence of 1 equivalent of $\mathrm{NaClO}_{4}$ in $\mathrm{CH}_{3} \mathrm{CN}$ and selected binding isotherms.
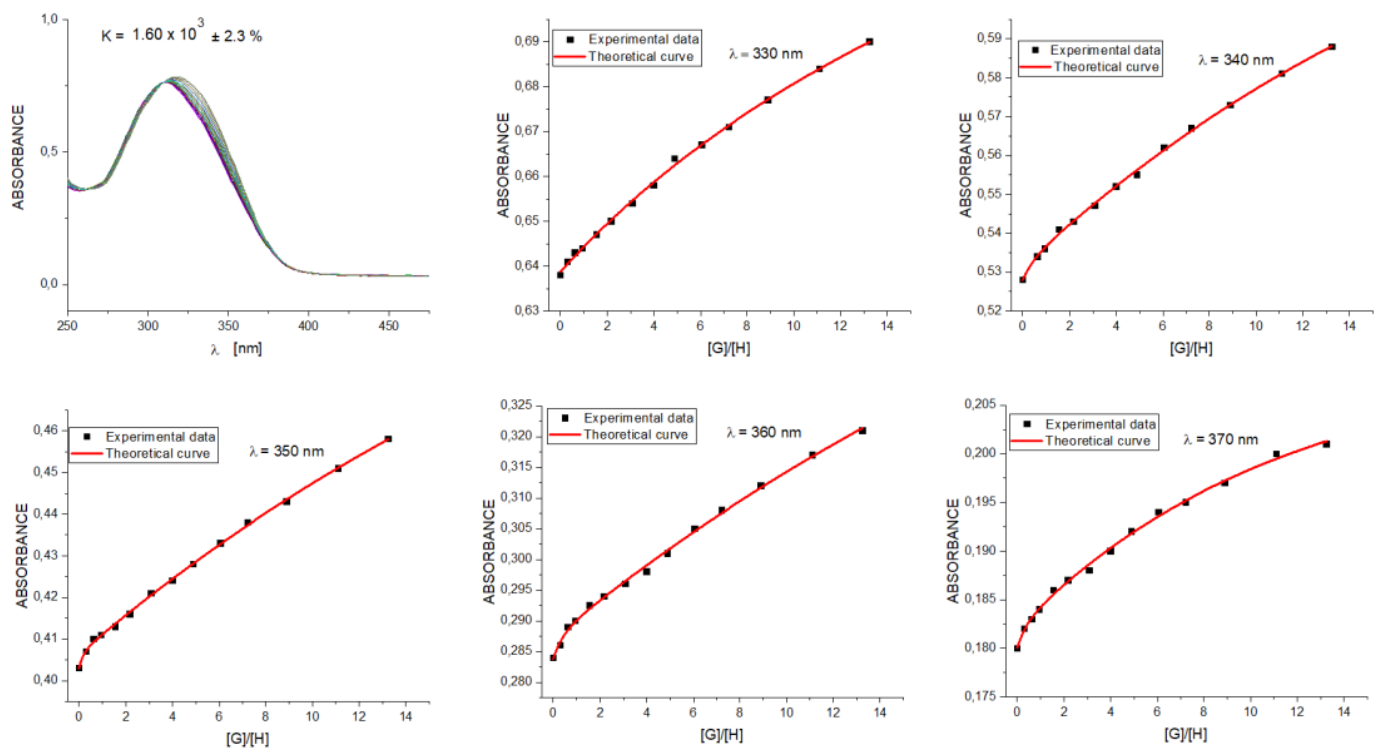

Fig. S17. UV-vis titration of receptor 1 with $\mathrm{TBANO}_{3}$ in $\mathrm{CH}_{3} \mathrm{CN}$ and selected binding isotherms. 

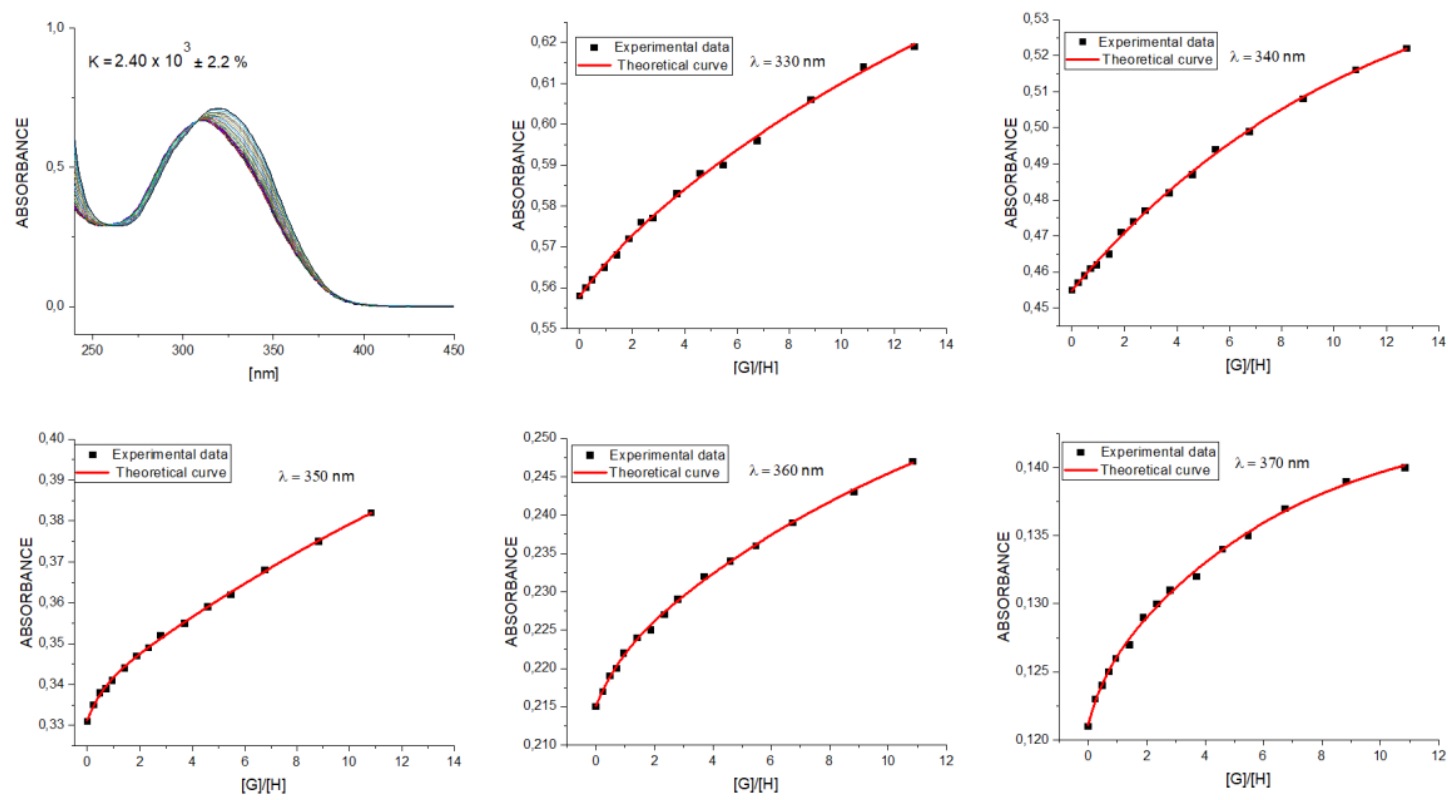

Fig. S18. UV-vis titration of receptor 1 with $\mathrm{TBANO}_{3}$ in the presence of 1 equivalent of $\mathrm{NaClO}_{4}$ in $\mathrm{CH}_{3} \mathrm{CN}$ and selected binding isotherms.
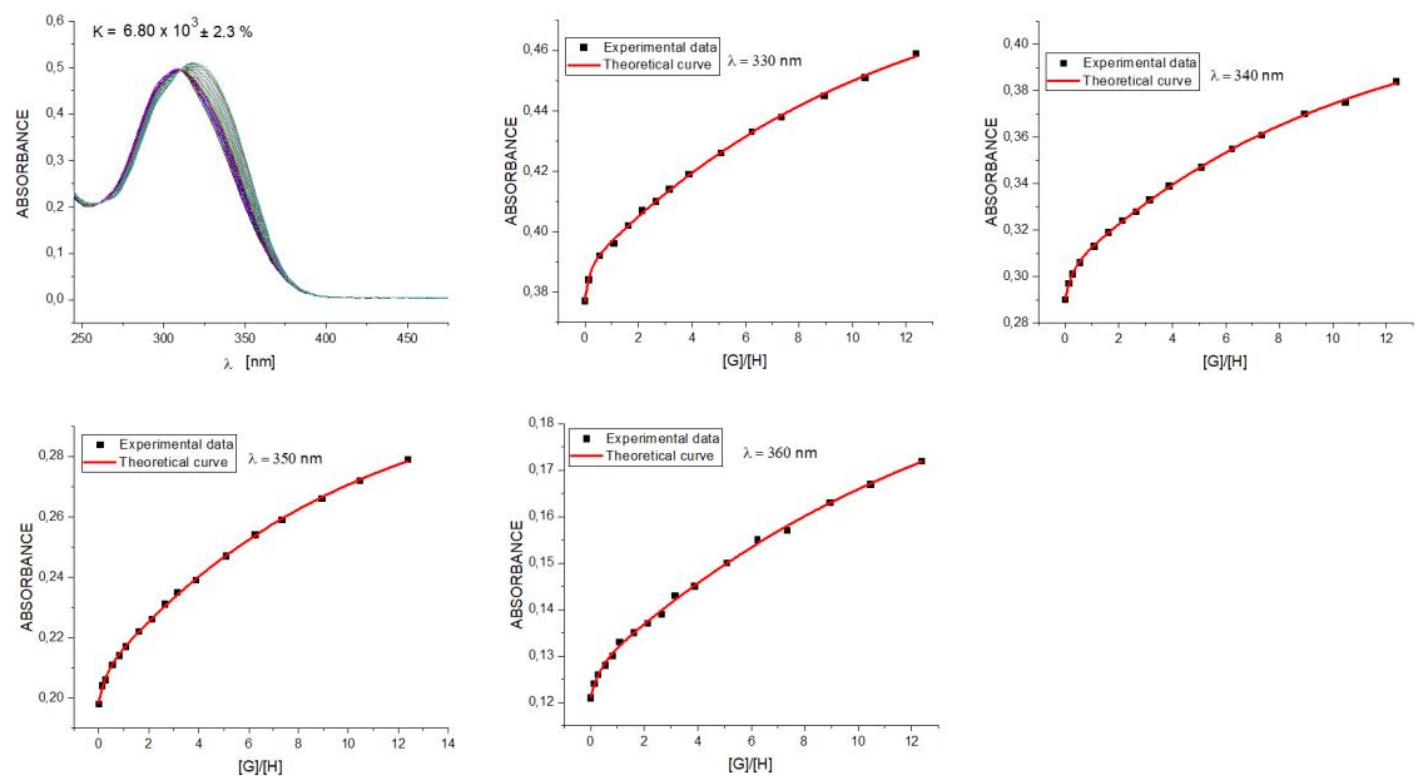

Fig. S19. UV-vis titration of receptor 1 with $\mathrm{TBAHSO}_{4}$ in $\mathrm{CH}_{3} \mathrm{CN}$ and selected binding isotherms. 

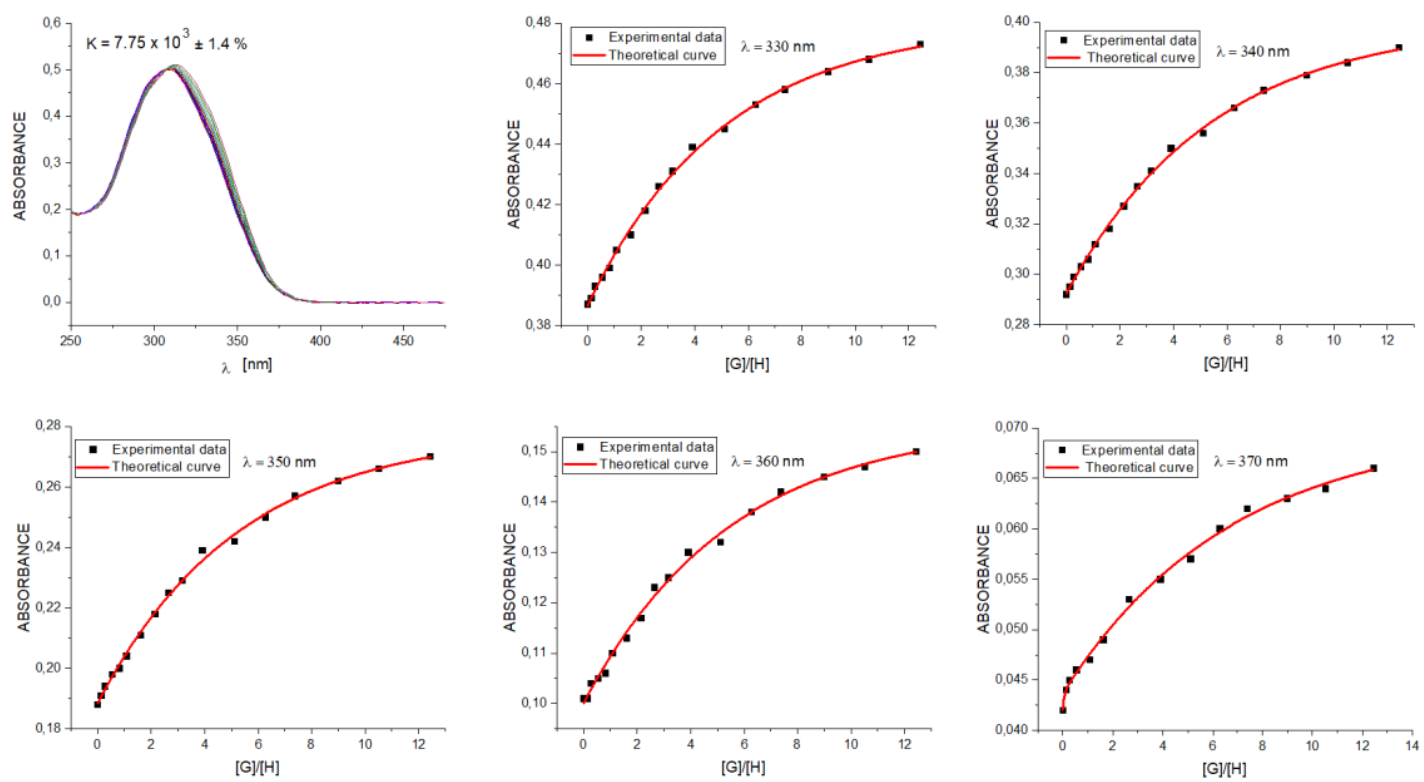

Fig. S20. UV-vis titration of receptor 1 with $\mathrm{TBAHSO}_{4}$ in the presence of 1 equivalent of $\mathrm{NaClO}_{4}$ in $\mathrm{CH}_{3} \mathrm{CN}$ and selected binding isotherms.
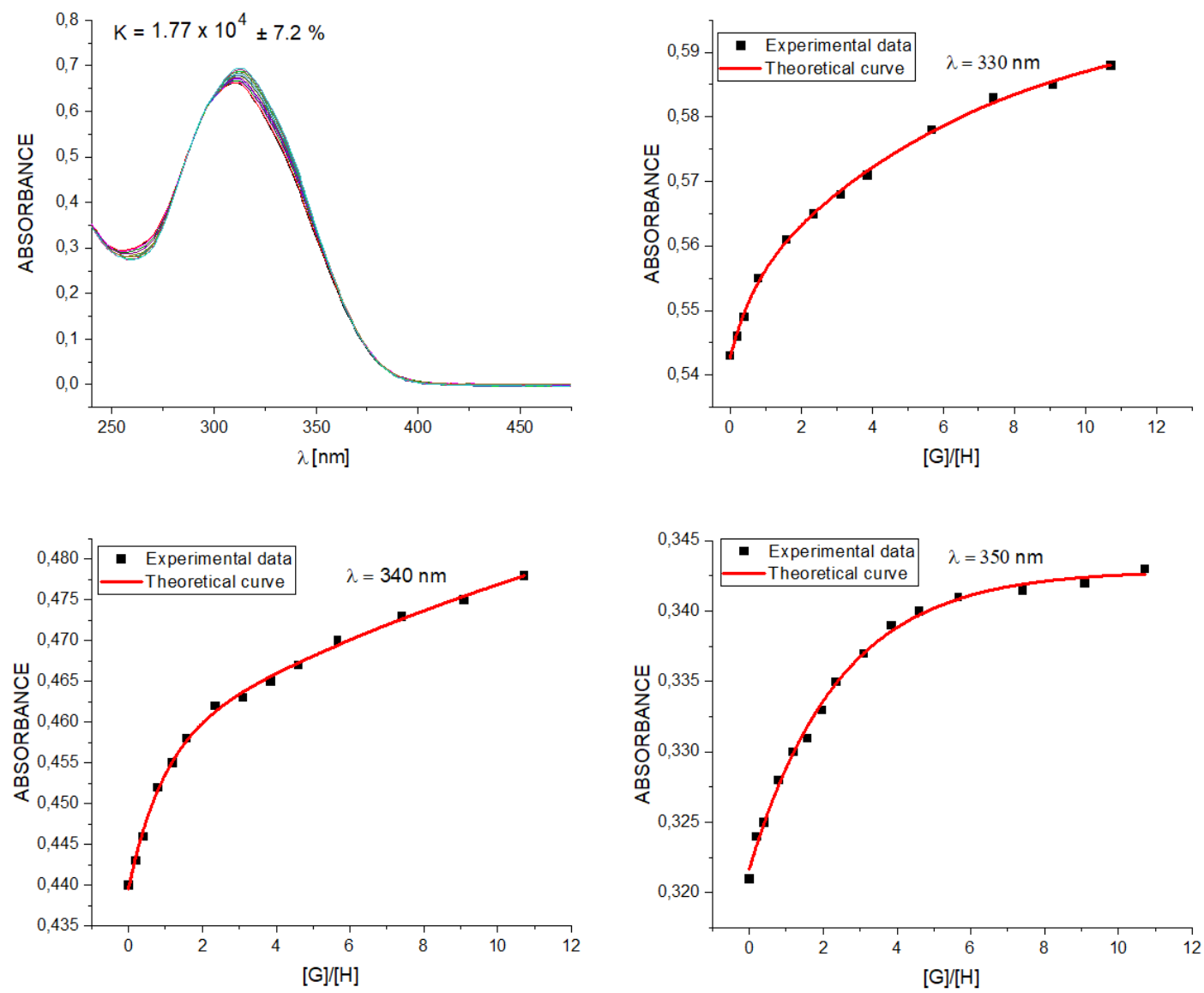

Fig. S21. UV-vis titration of receptor 1 with $\mathrm{NaClO}_{4}$ in $\mathrm{CH}_{3} \mathrm{CN}$ and selected binding isotherms. 

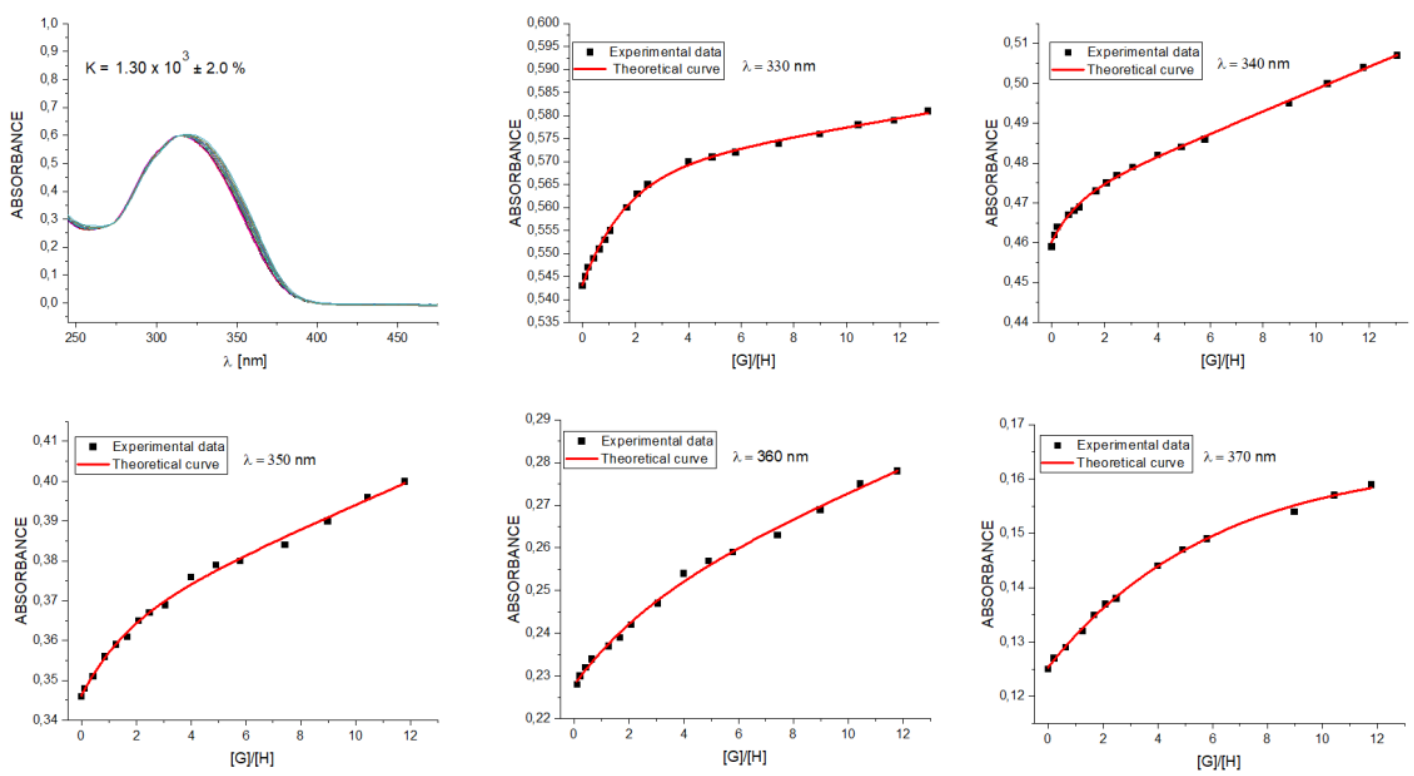

Fig. S22. UV-vis titration of receptor 1 with $\mathrm{TBACl}$ in $5 \% \mathrm{H}_{2} \mathrm{O}\left(\mathrm{pH}=3\right.$ with $\left.\mathrm{HClO}_{4}\right)$ in $\mathrm{CH}_{3} \mathrm{CN}$ and selected binding isotherms.
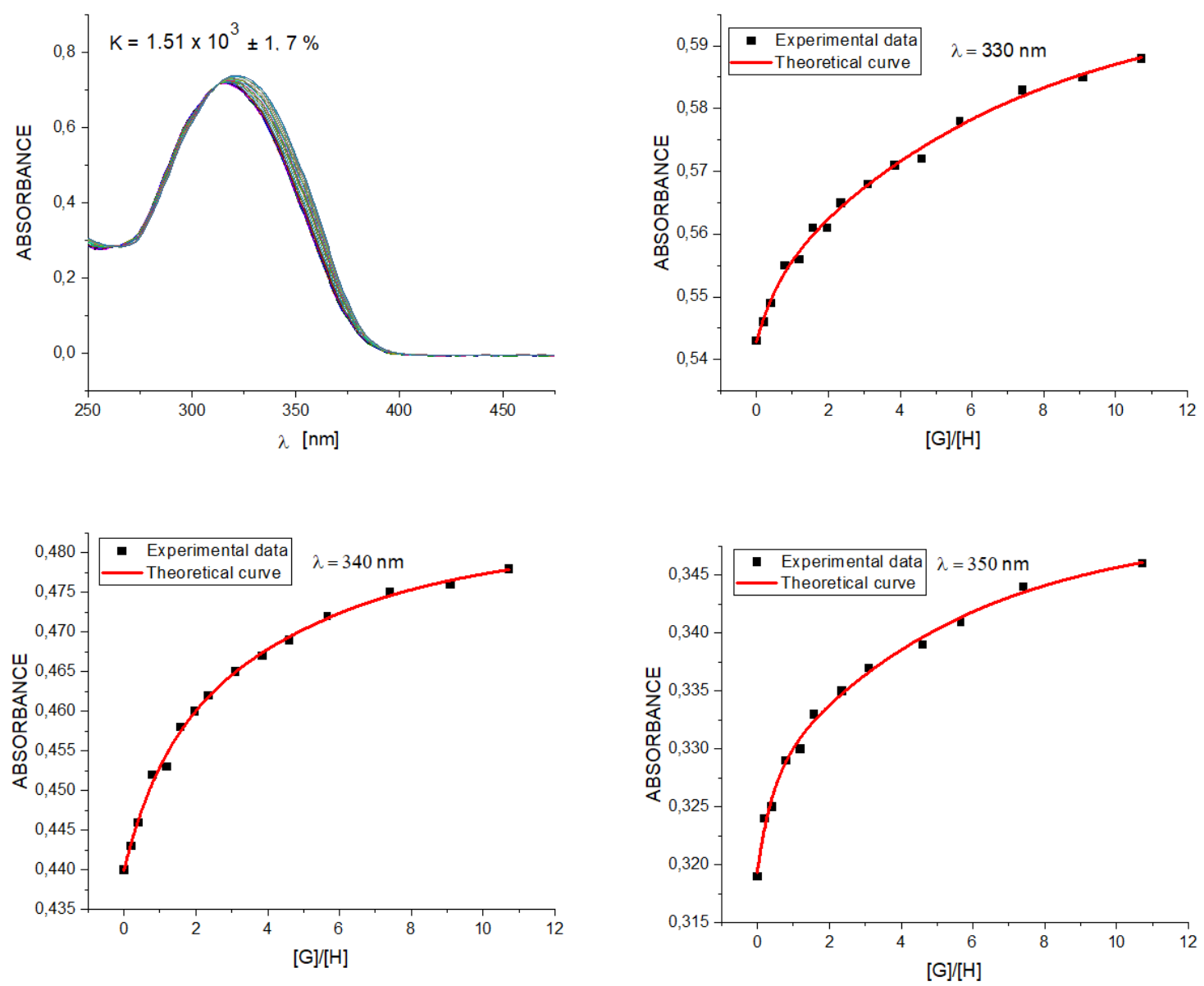

Fig. S23. UV-vis titration of receptor 1 with $\mathrm{NaCl}$ in $5 \% \mathrm{H}_{2} \mathrm{O}\left(\mathrm{pH}=3\right.$ with $\left.\mathrm{HClO}_{4}\right)$ in $\mathrm{CH}_{3} \mathrm{CN}$ and selected binding isotherms. 

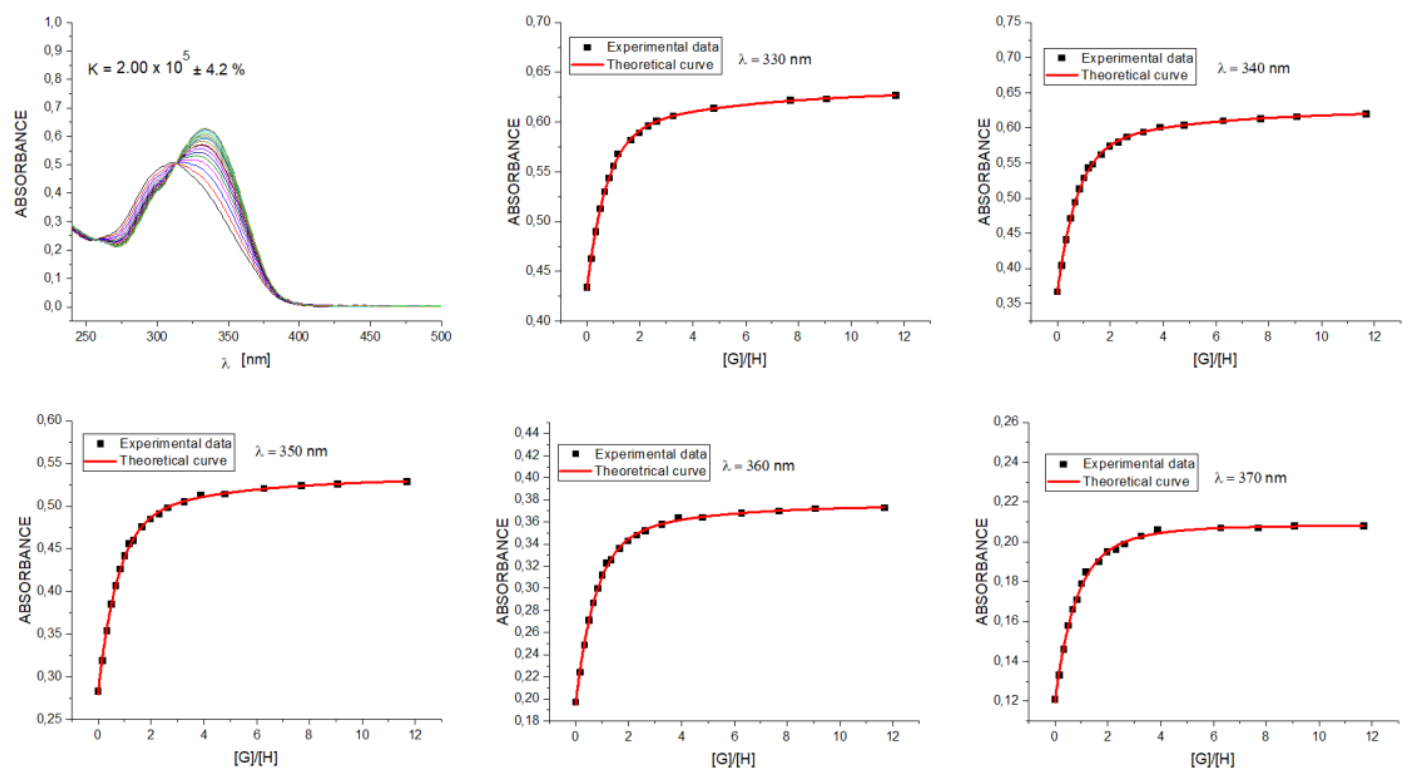

Fig. S24. UV-vis titration of receptor 2 with $\mathrm{TBACl}$ in $\mathrm{CH}_{3} \mathrm{CN}$ and selected binding isotherms.
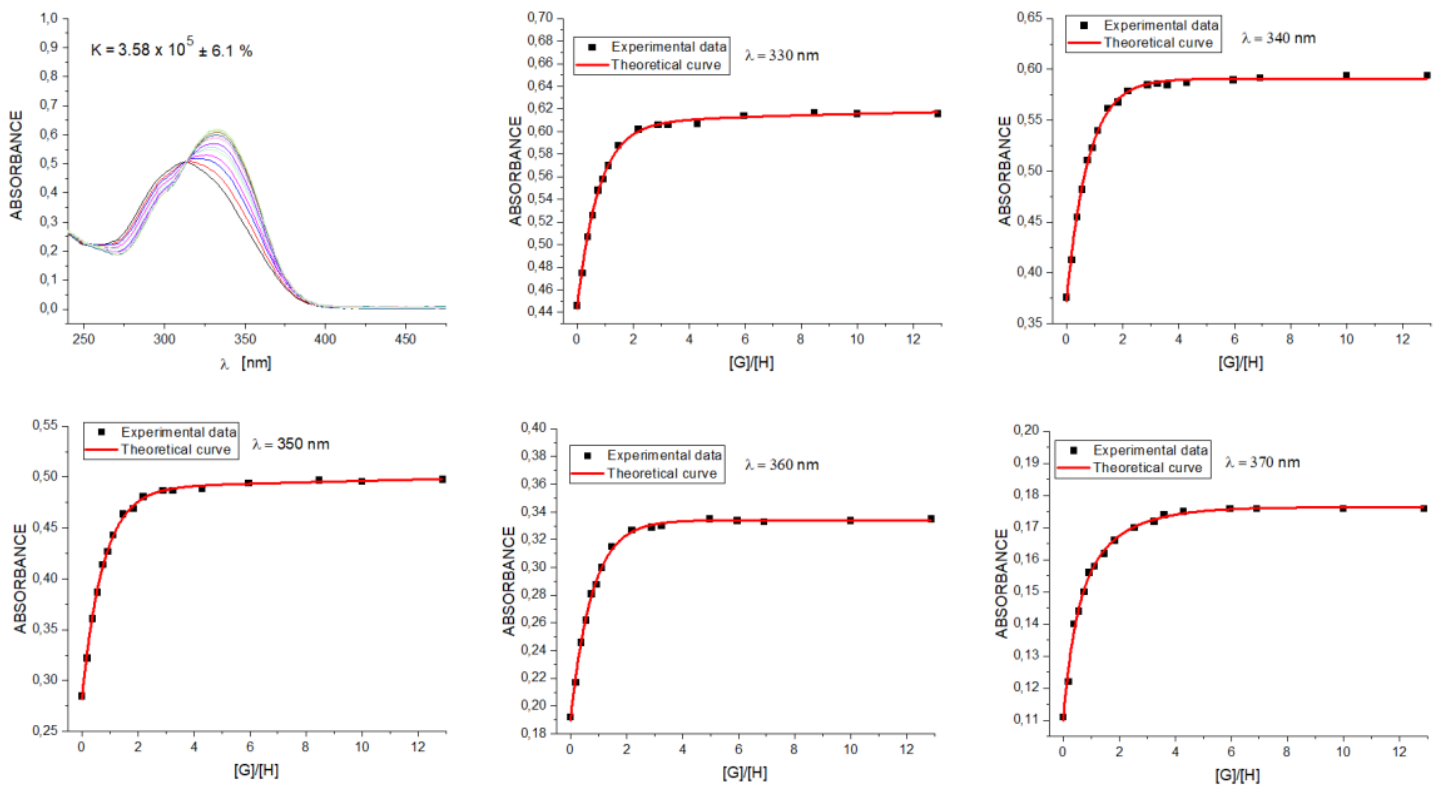

Fig. S25. UV-vis titration of receptor 2 with TBACl in the presence of 1 equivalent of $\mathrm{NaClO}_{4}$ in $\mathrm{CH}_{3} \mathrm{CN}$ and selected binding isotherms. 

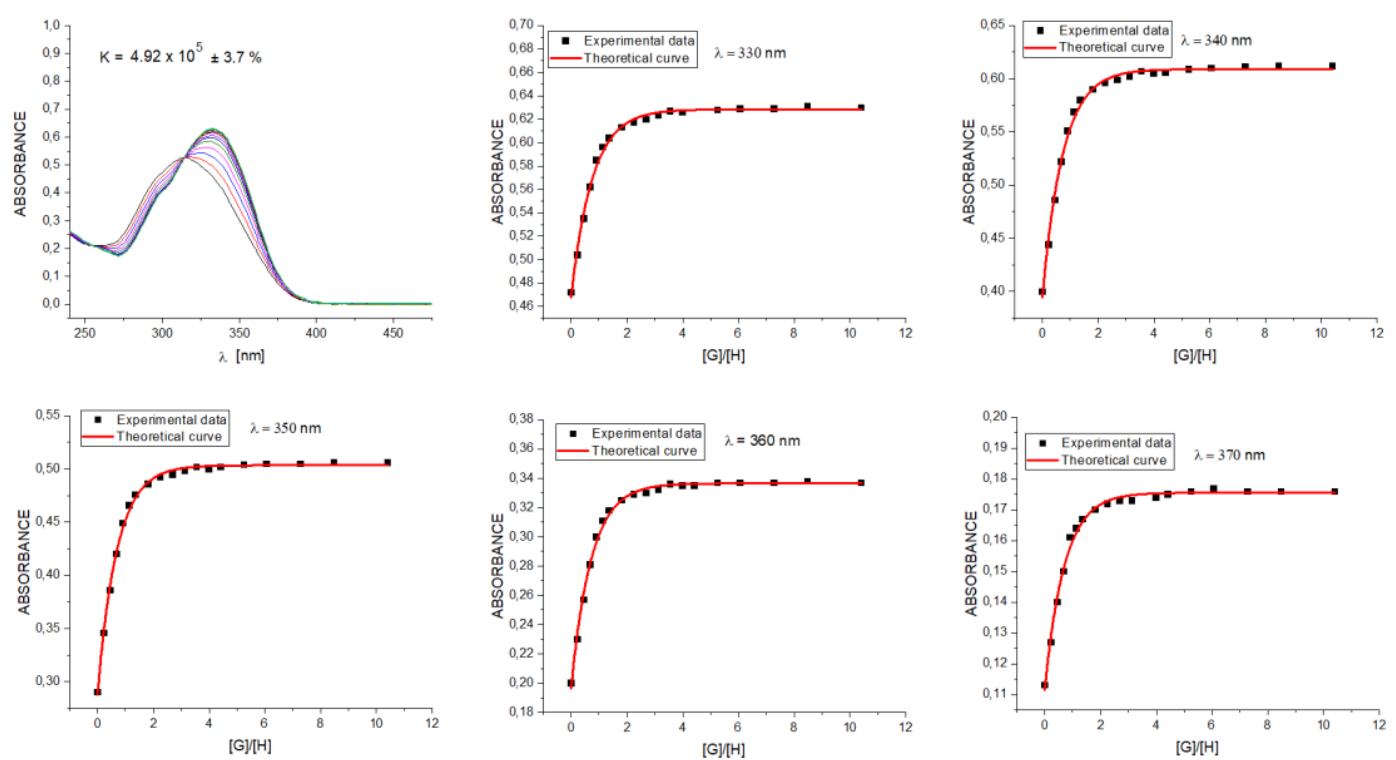

Fig. S26. UV-vis titration of receptor 2 with $\mathrm{TBACl}$ in the presence of 1 equivalent of $\mathrm{KPF}_{6}$ in $\mathrm{CH}_{3} \mathrm{CN}$ and selected binding isotherms.
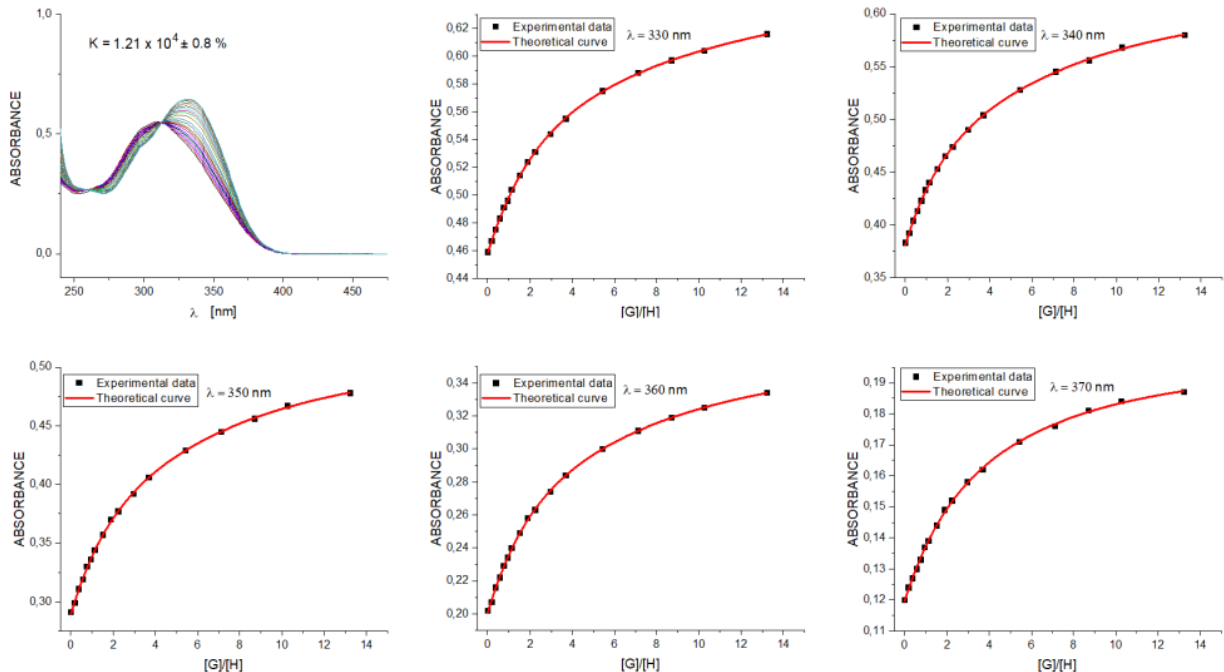

Fig. S27. UV-vis titration of receptor 2 with $\mathrm{TBABr}$ in $\mathrm{CH}_{3} \mathrm{CN}$ and selected binding isotherms. 

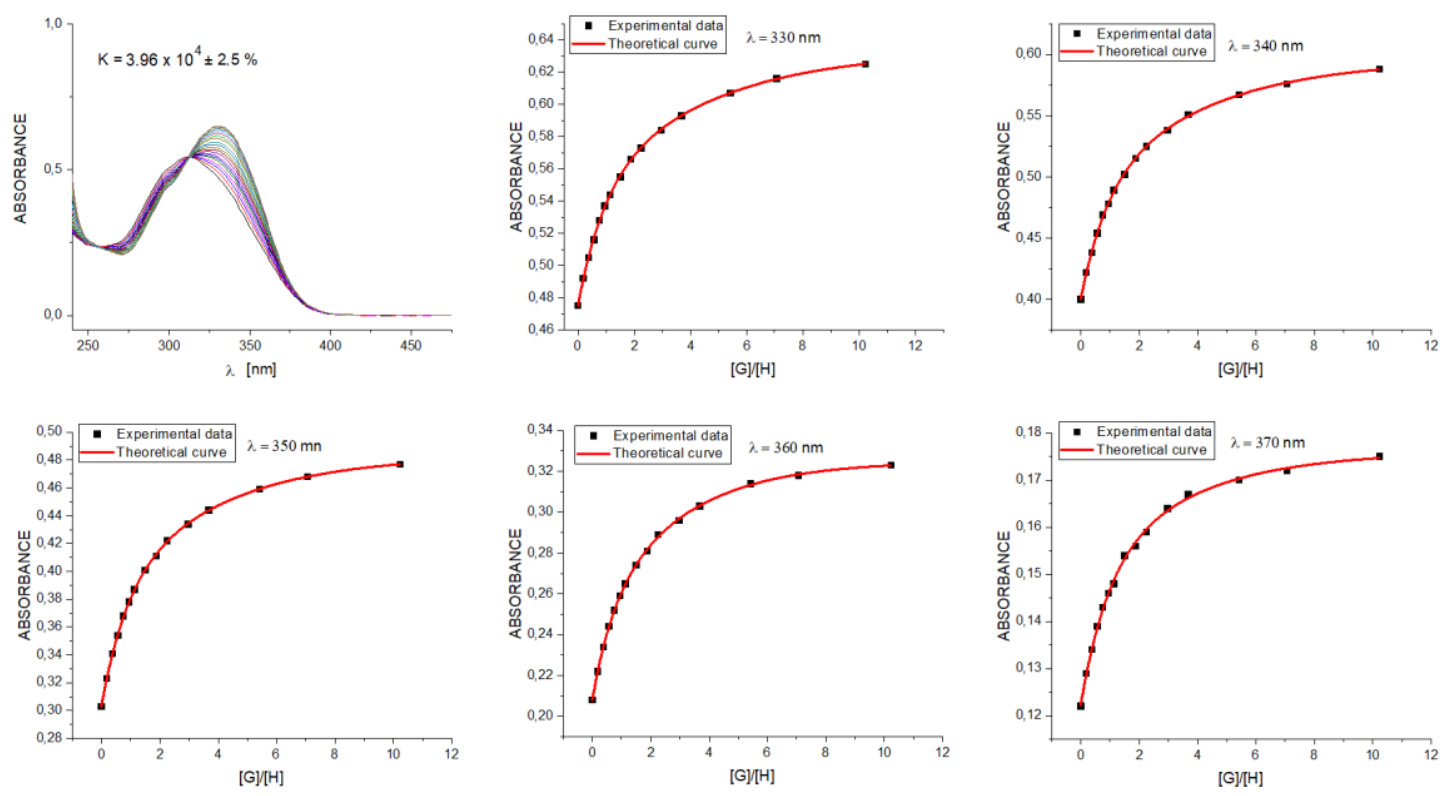

Fig. S28. UV-vis titration of receptor 2 with $\mathrm{TBABr}$ in the presence of 1 equivalent of $\mathrm{NaClO}_{4}$ in $\mathrm{CH}_{3} \mathrm{CN}$ and selected binding isotherms.
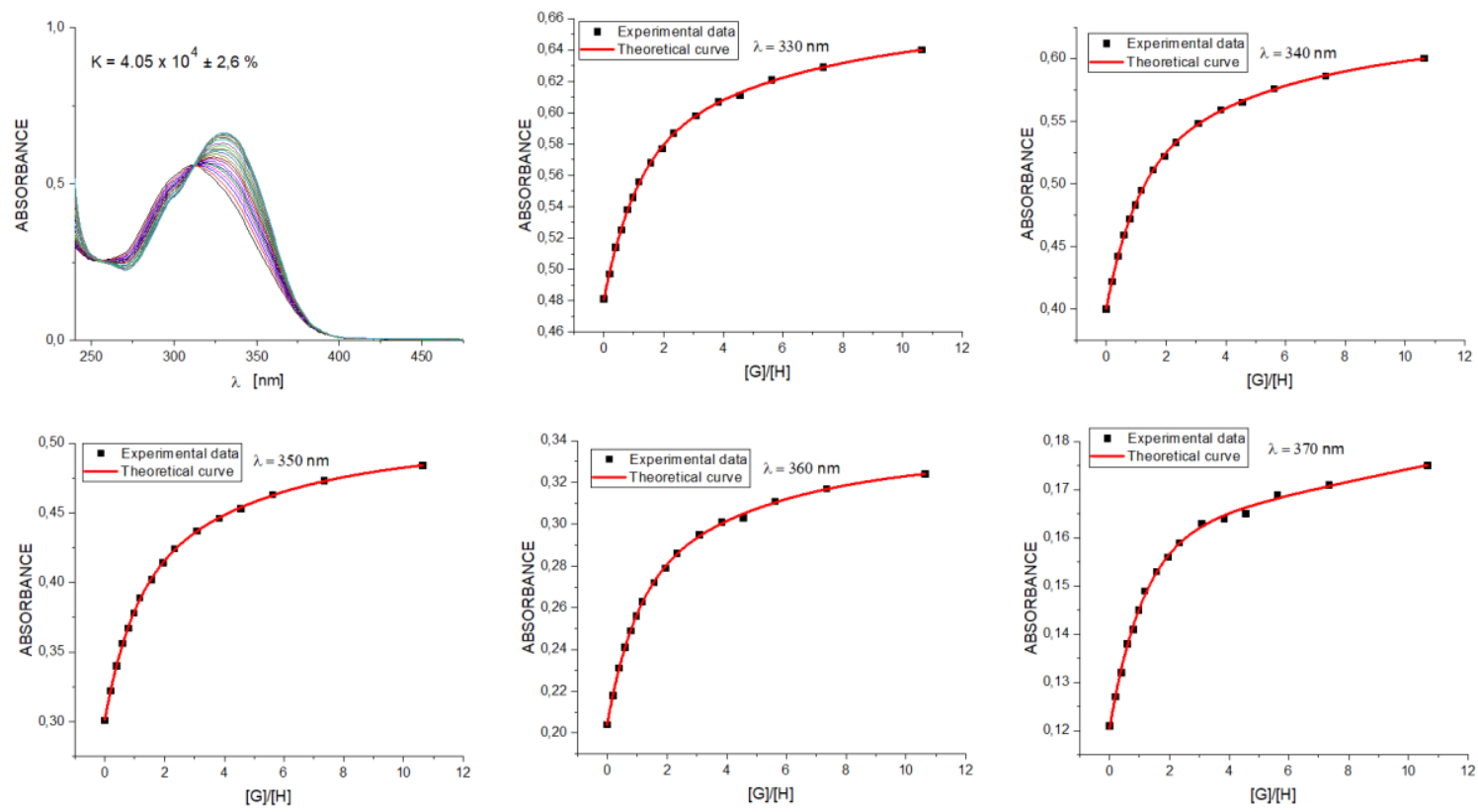

Fig. S29. UV-vis titration of receptor 2 with $\mathrm{TBABr}$ in the presence of 1 equivalent of $\mathrm{KPF}_{6}$ in $\mathrm{CH}_{3} \mathrm{CN}$ and selected binding isotherms. 

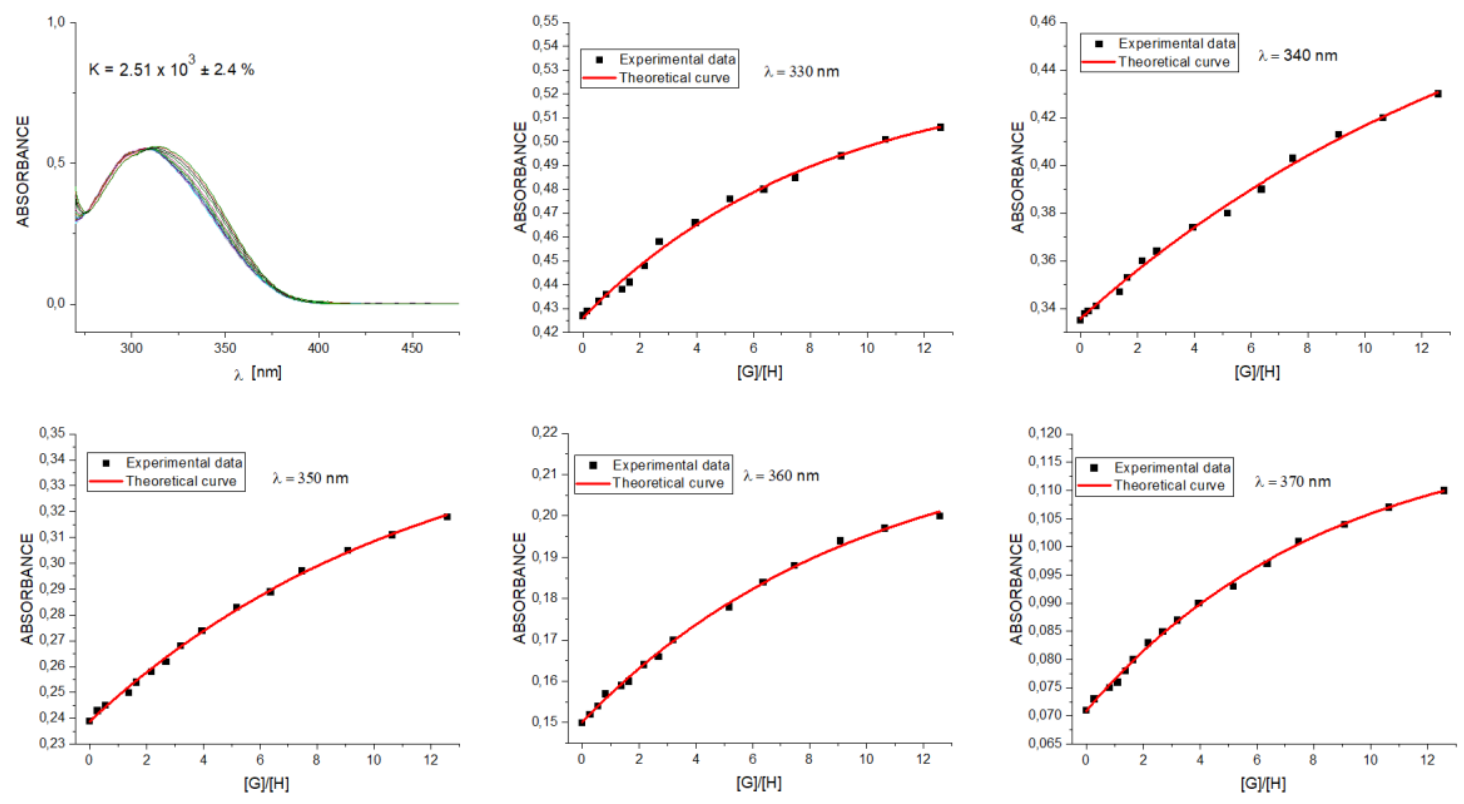

Fig. S30. UV-vis titration of receptor 2 with TBAI in $\mathrm{CH}_{3} \mathrm{CN}$ and selected binding isotherms.
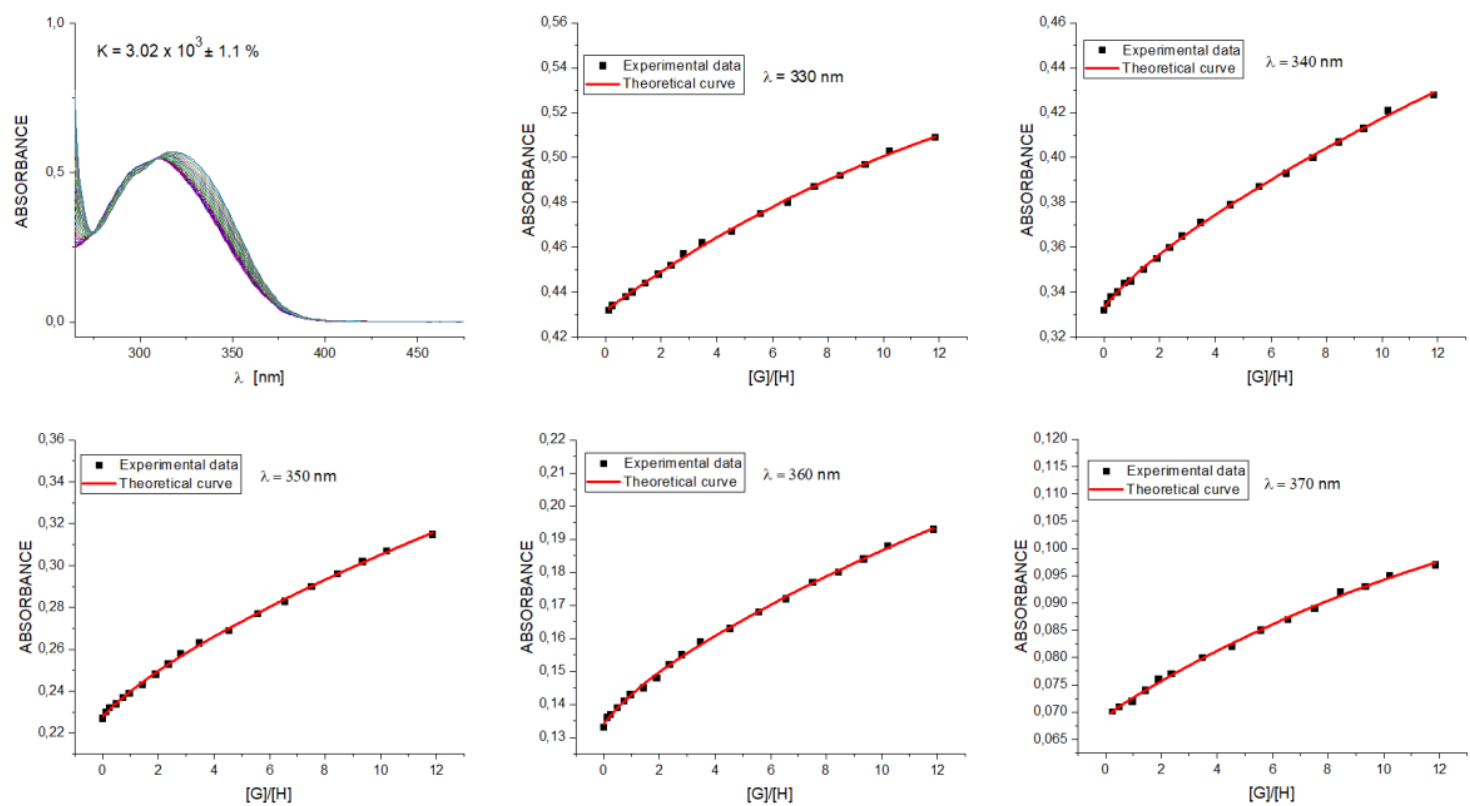

Fig. S31. UV-vis titration of receptor 2 with TBAI in the presence of 1 equivalent of $\mathrm{NaClO}_{4}$ in $\mathrm{CH}_{3} \mathrm{CN}$ and selected binding isotherms. 

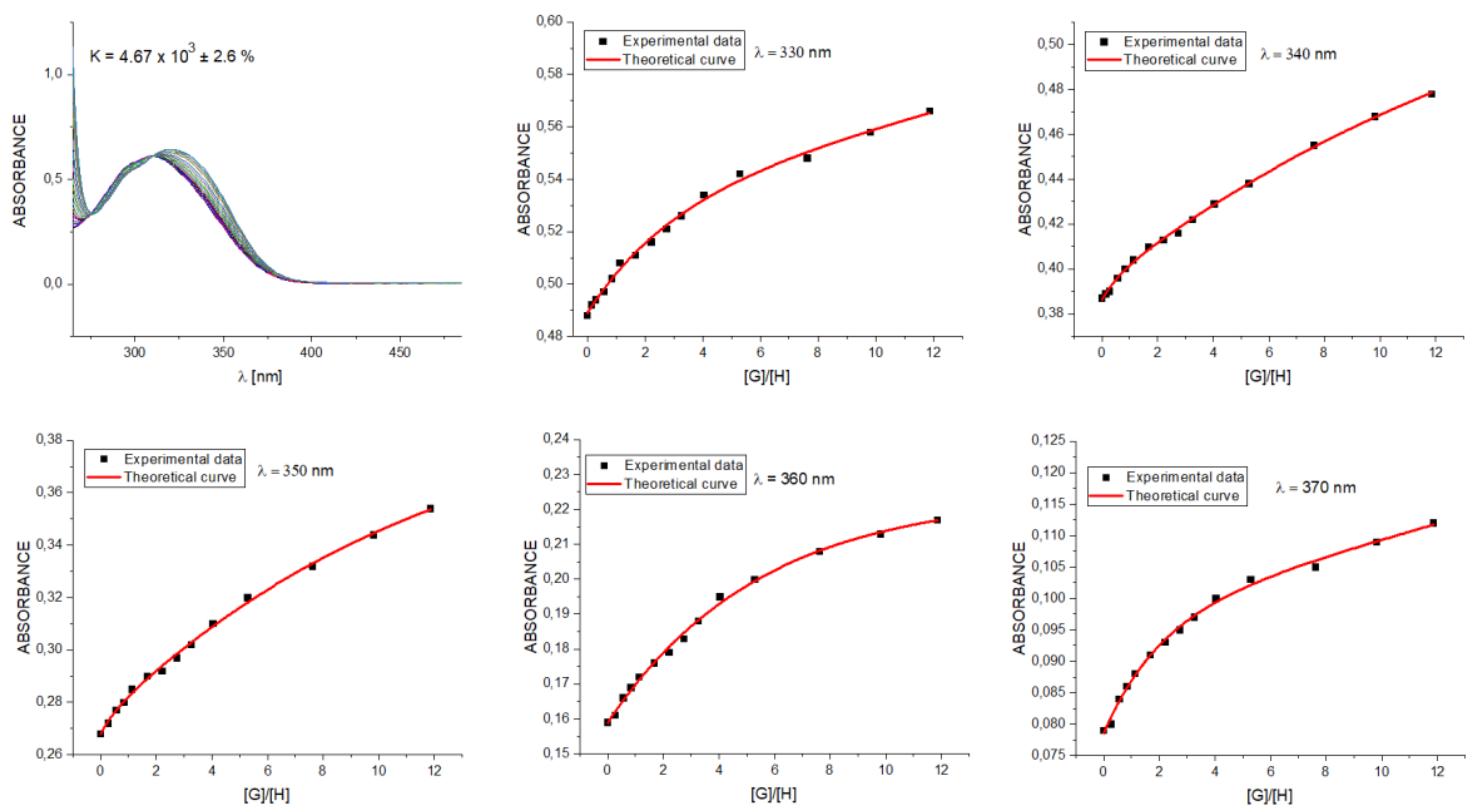

Fig. S32. UV-vis titration of receptor 2 with TBAI in the presence of 1 equivalent of $\mathrm{KPF}_{6}$ in $\mathrm{CH}_{3} \mathrm{CN}$ and selected binding isotherms.
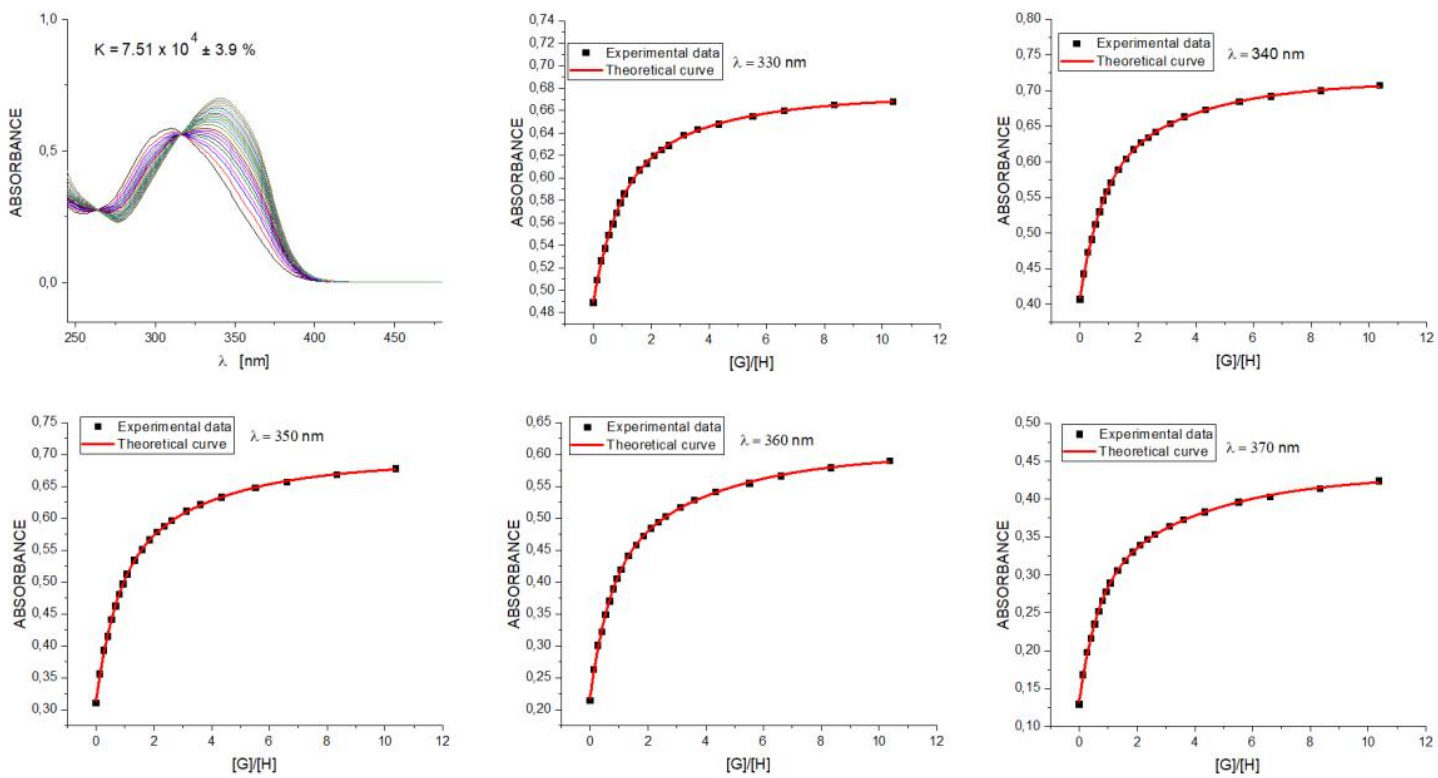

Fig. S33. UV-vis titration of receptor 2 with $\mathrm{TBANO}_{2}$ in $\mathrm{CH}_{3} \mathrm{CN}$ and selected binding isotherms. 

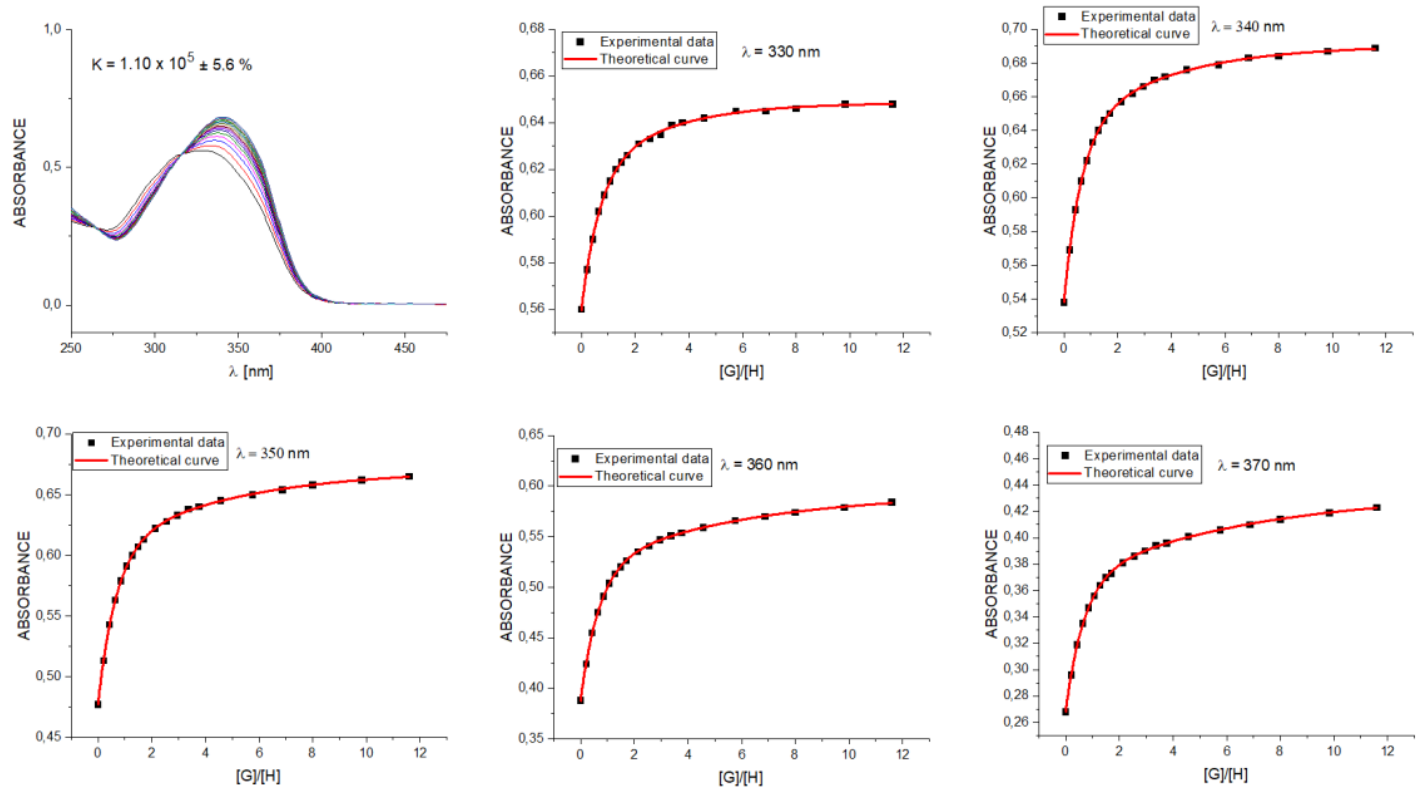

Fig. S34. UV-vis titration of receptor 2 with $\mathrm{TBANO}_{2}$ in the presence of 1 equivalent of $\mathrm{NaClO}_{4}$ in $\mathrm{CH}_{3} \mathrm{CN}$ and selected binding isotherms.
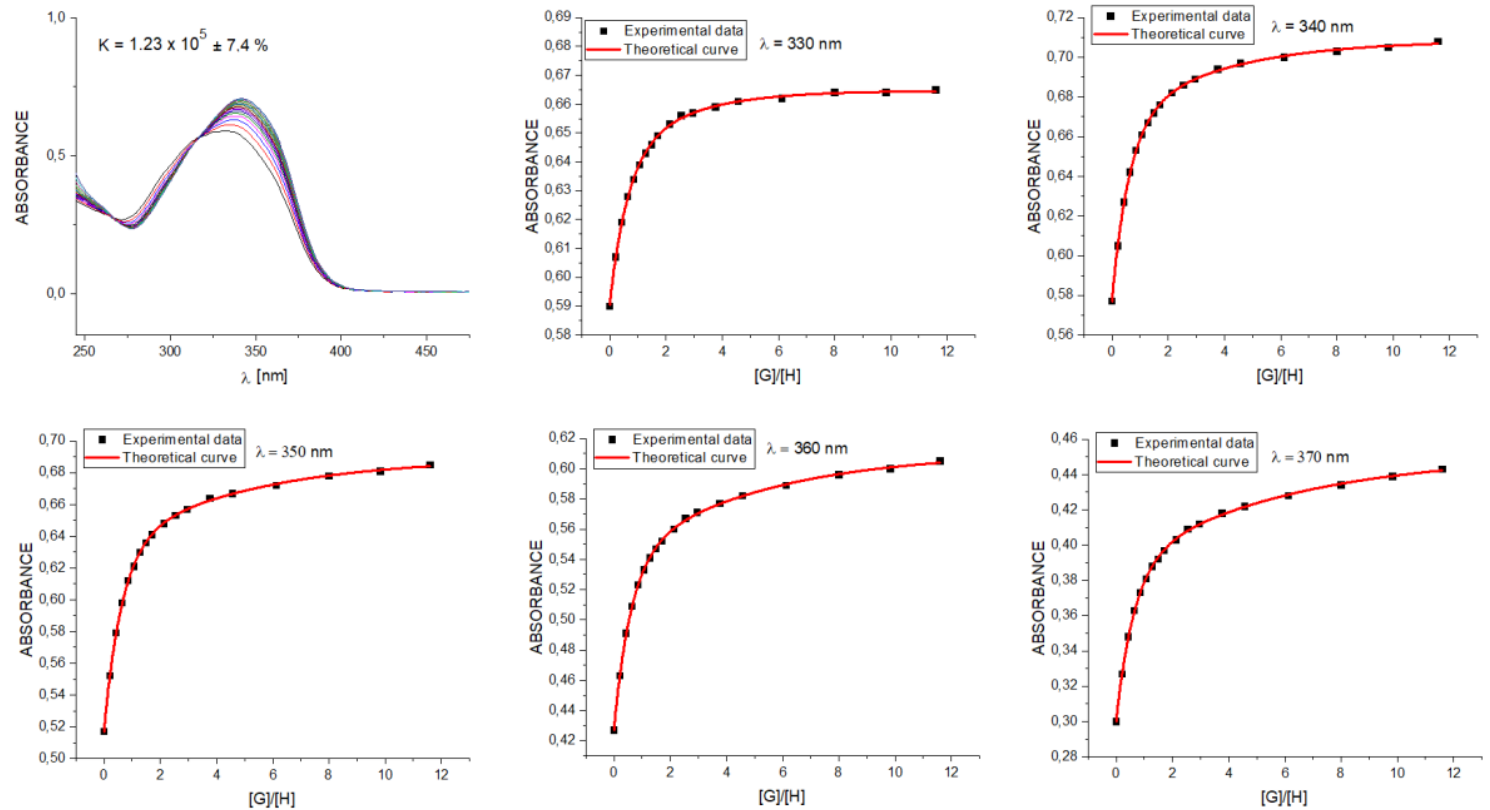

Fig. S35. UV-vis titration of receptor 2 with $\mathrm{TBANO}_{2}$ in the presence of 1 equivalent of $\mathrm{KPF}_{6}$ in $\mathrm{CH}_{3} \mathrm{CN}$ and selected binding isotherms. 

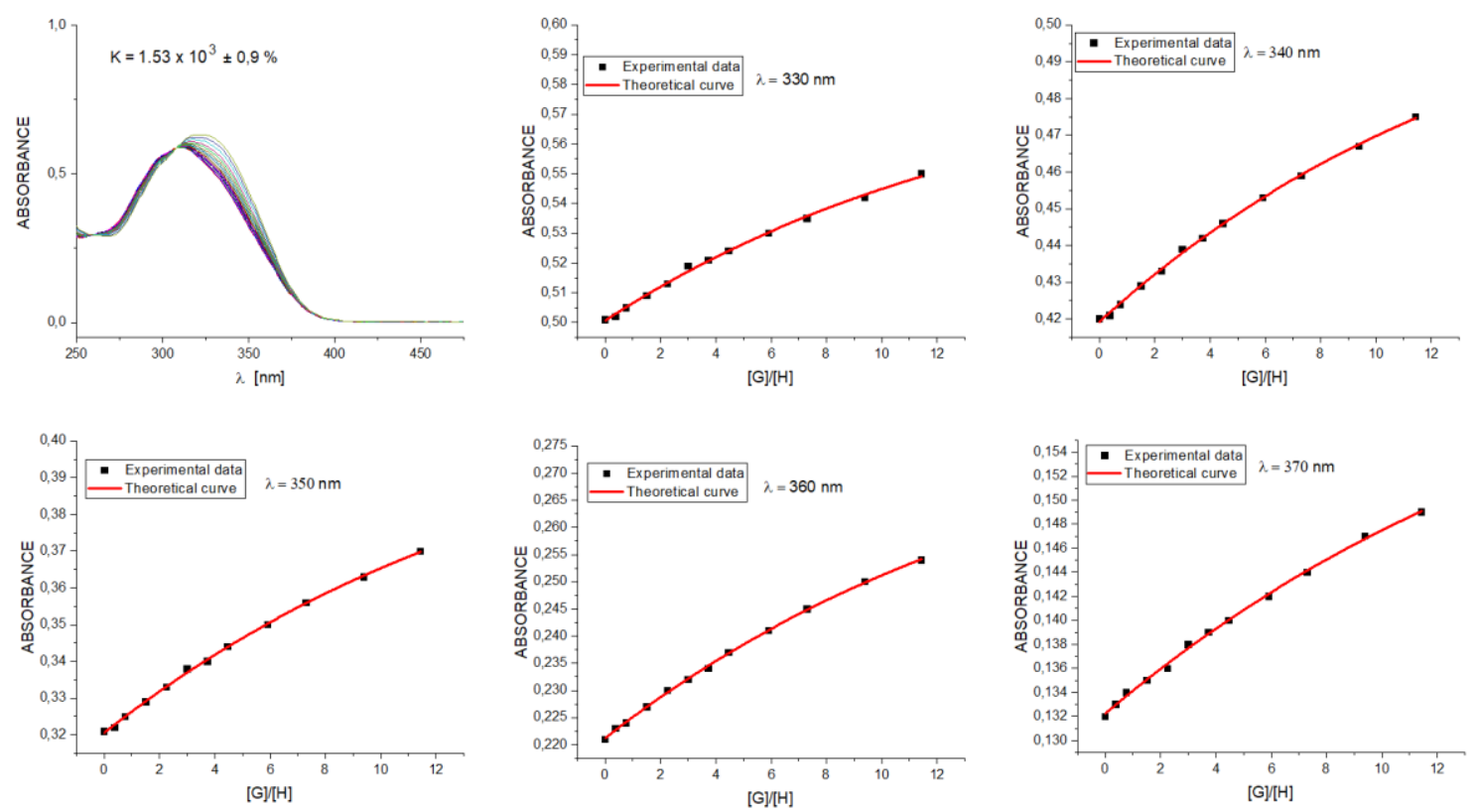

Fig. S36. UV-vis titration of receptor 2 with $\mathrm{TBANO}_{3}$ in $\mathrm{CH}_{3} \mathrm{CN}$ and selected binding isotherms.
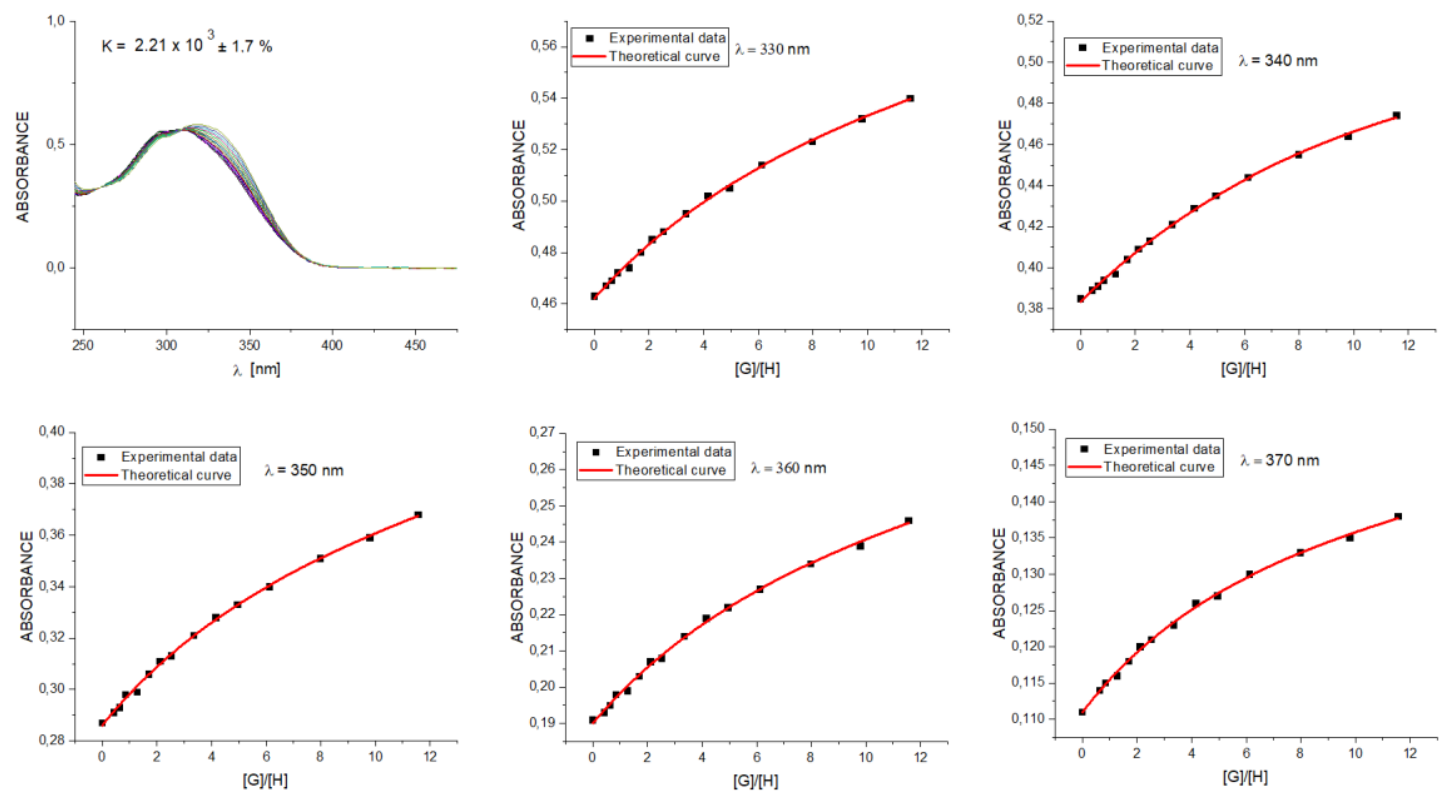

Fig. S37. UV-vis titration of receptor 2 with $\mathrm{TBANO}_{3}$ in the presence of 1 equivalent of $\mathrm{NaClO}_{4}$ in $\mathrm{CH}_{3} \mathrm{CN}$ and selected binding isotherms. 

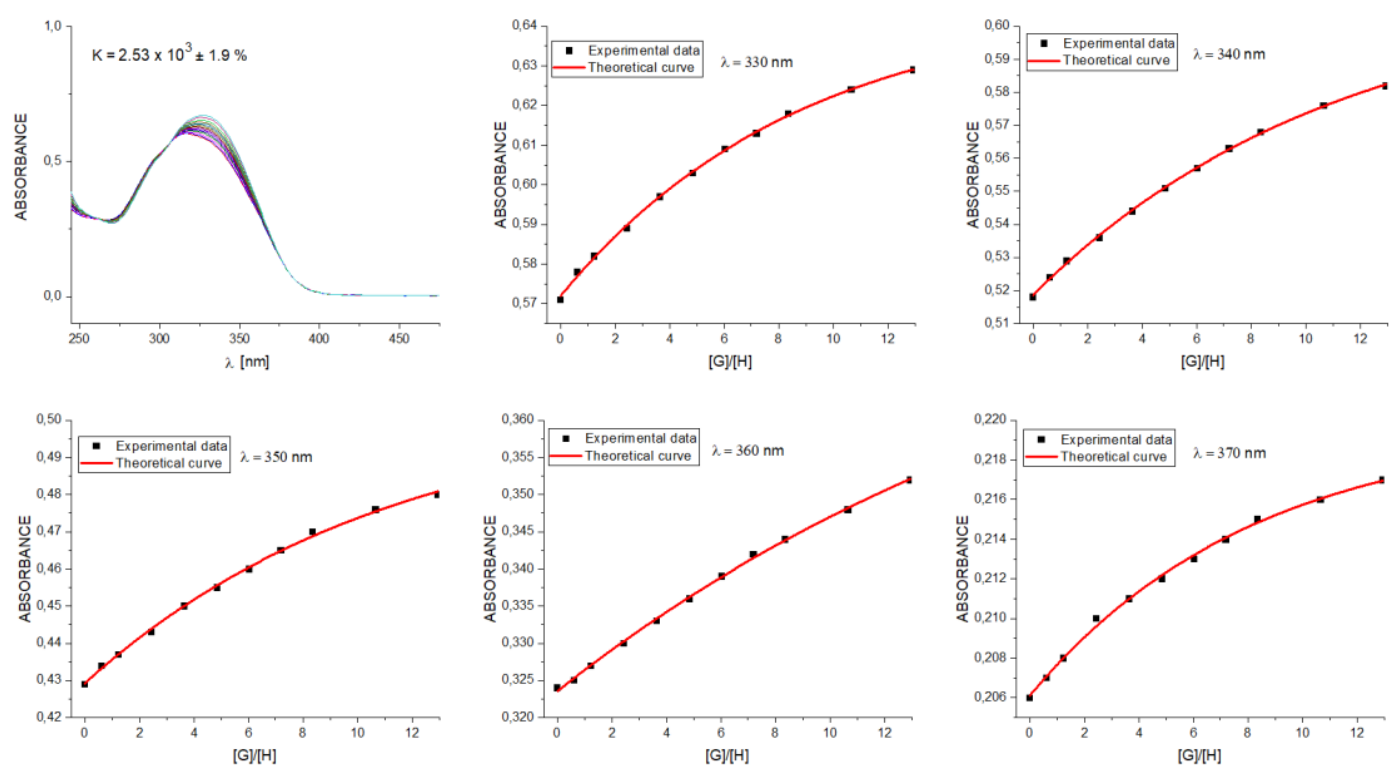

Fig. S38. UV-vis titration of receptor 2 with $\mathrm{TBANO}_{3}$ in the presence of 1 equivalent of $\mathrm{KPF}_{6}$ in $\mathrm{CH}_{3} \mathrm{CN}$ and selected binding isotherms.
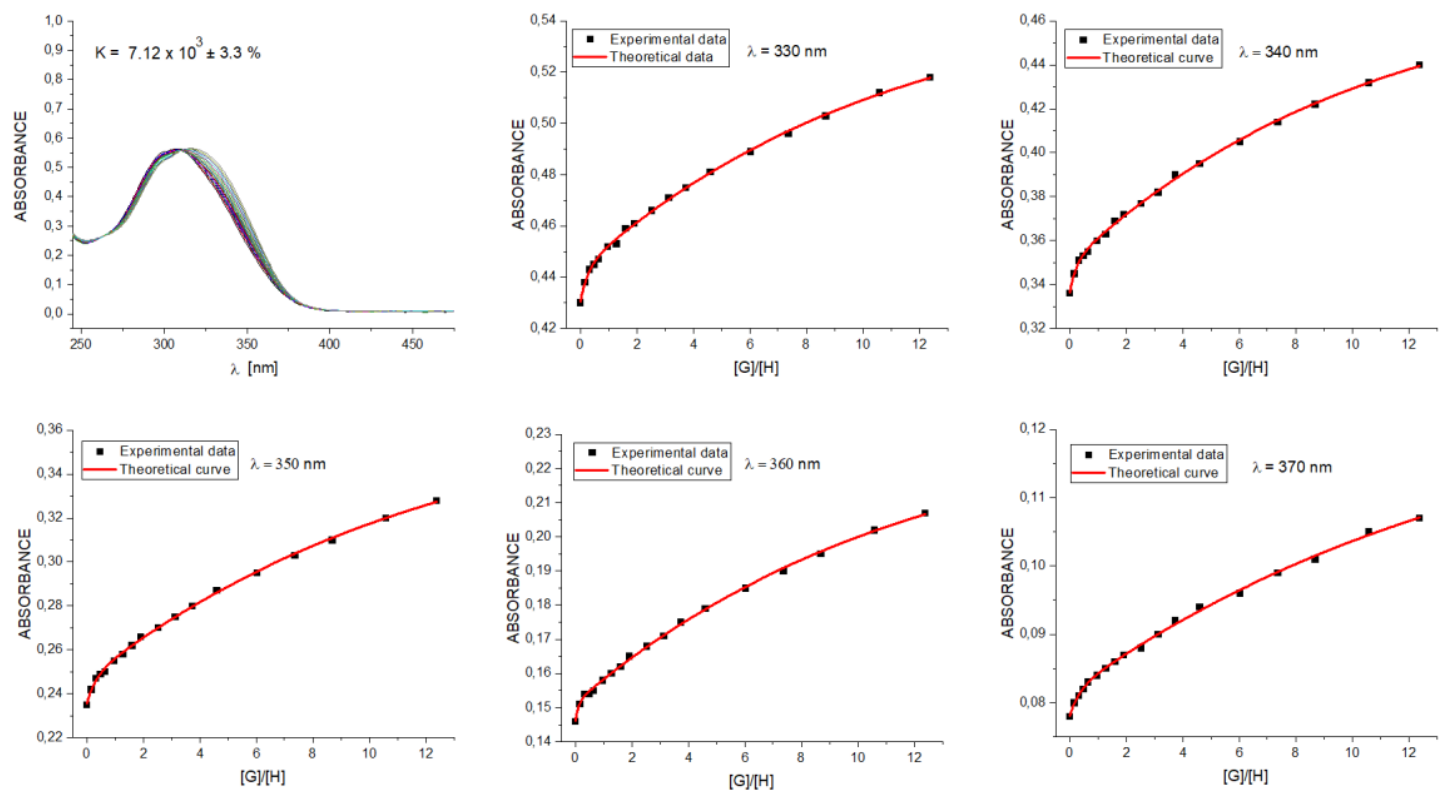

Fig. S39. UV-vis titration of receptor 2 with $\mathrm{TBAHSO}_{4}$ in $\mathrm{CH}_{3} \mathrm{CN}$ and selected binding isotherms. 

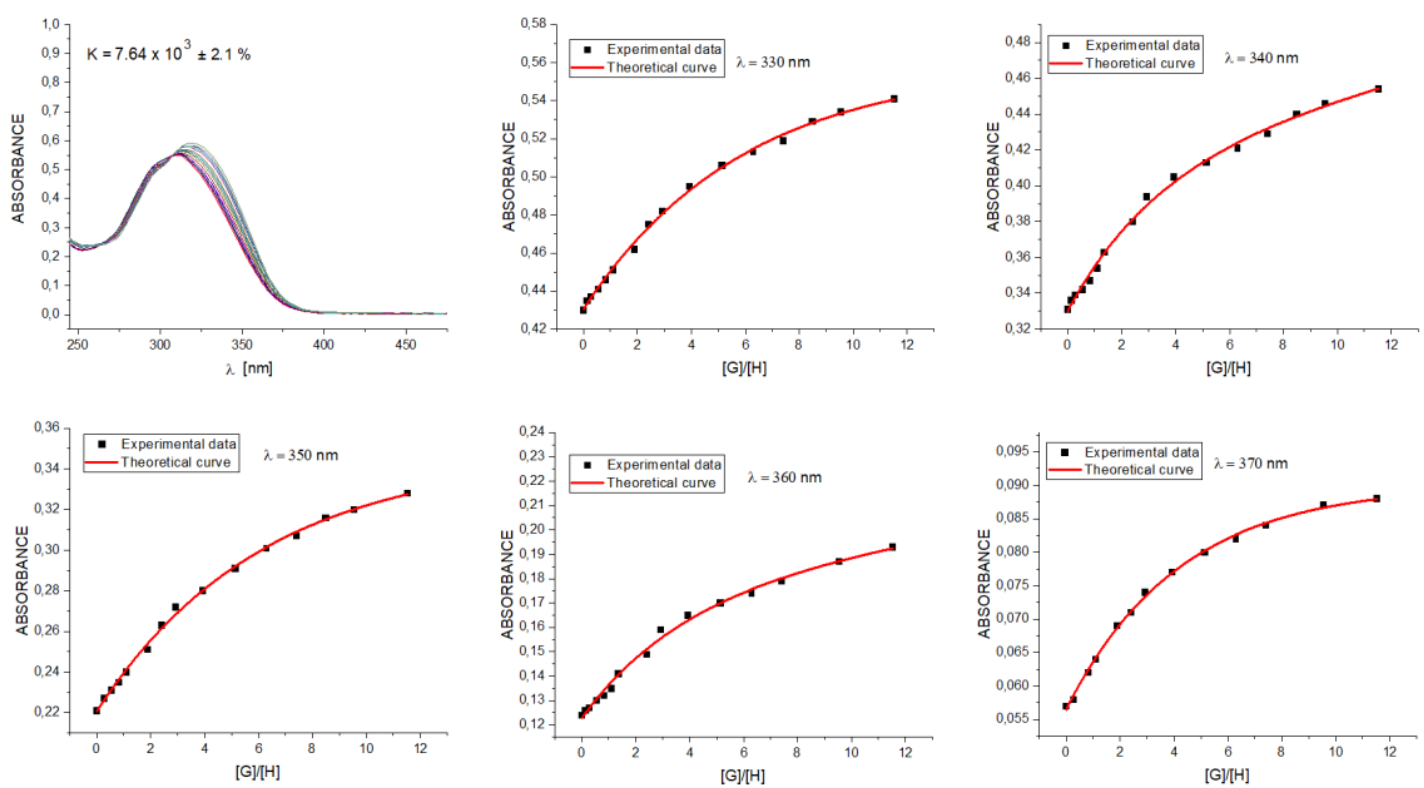

Fig. S40. UV-vis titration of receptor 2 with $\mathrm{TBAHSO}_{4}$ in the presence of 1 equivalent of $\mathrm{NaClO}_{4}$ in $\mathrm{CH}_{3} \mathrm{CN}$ and selected binding isotherms.
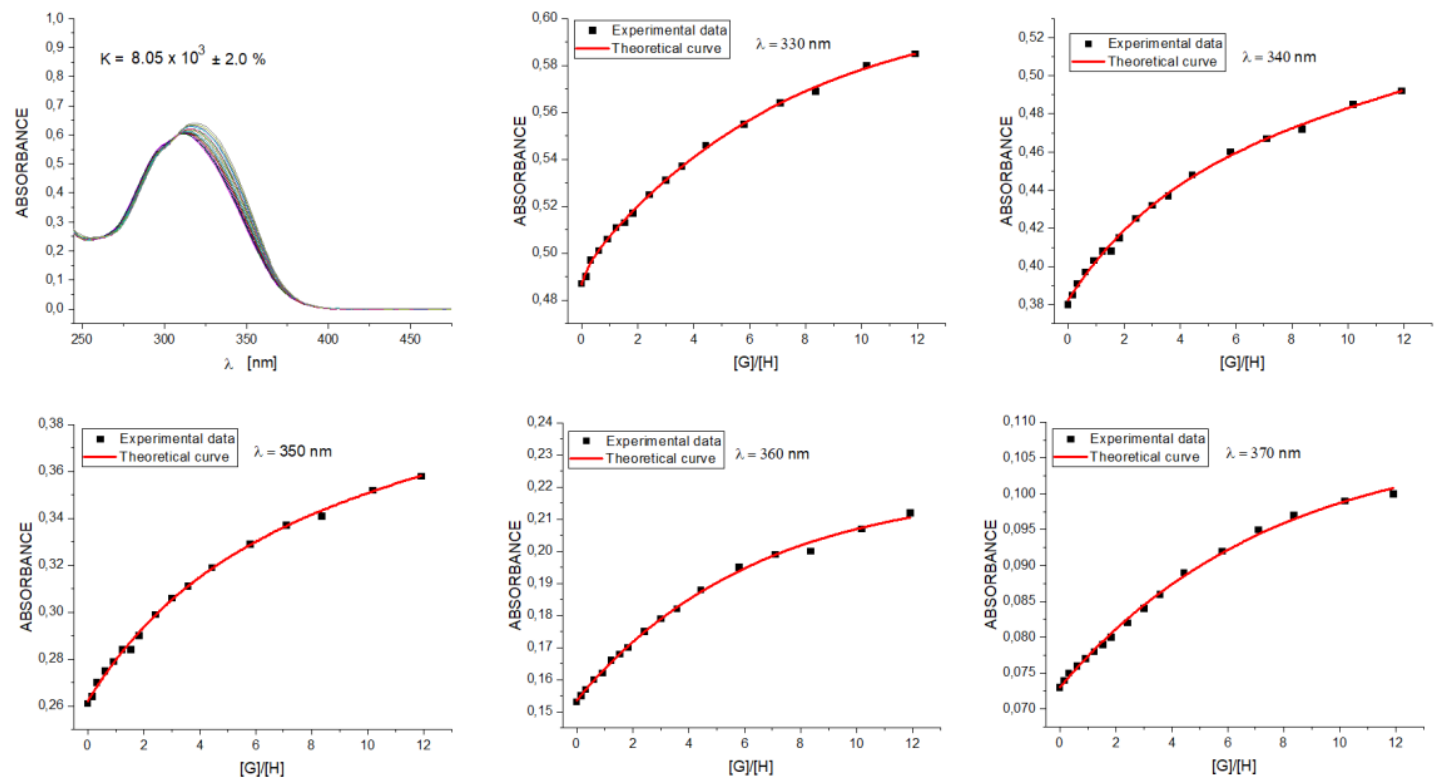

Fig. S41. UV-vis titration of receptor 2 with $\mathrm{TBAHSO}_{4}$ in the presence of 1 equivalent of $\mathrm{KPF}_{6}$ in $\mathrm{CH}_{3} \mathrm{CN}$ and selected binding isotherms. 

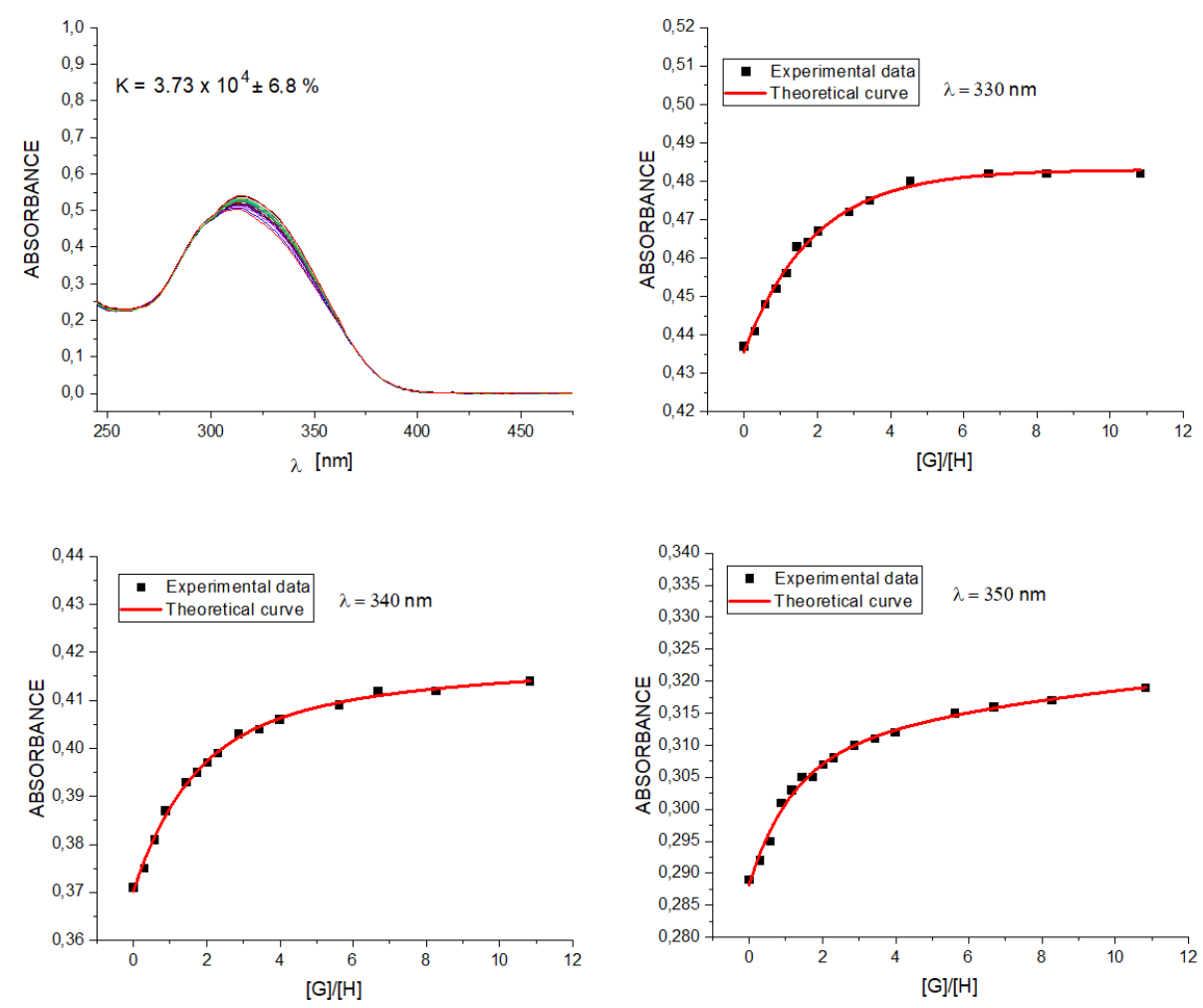

Fig. S42. UV-vis titration of receptor 2 with $\mathrm{NaClO}_{4}$ in $\mathrm{CH}_{3} \mathrm{CN}$ and selected binding isotherms.
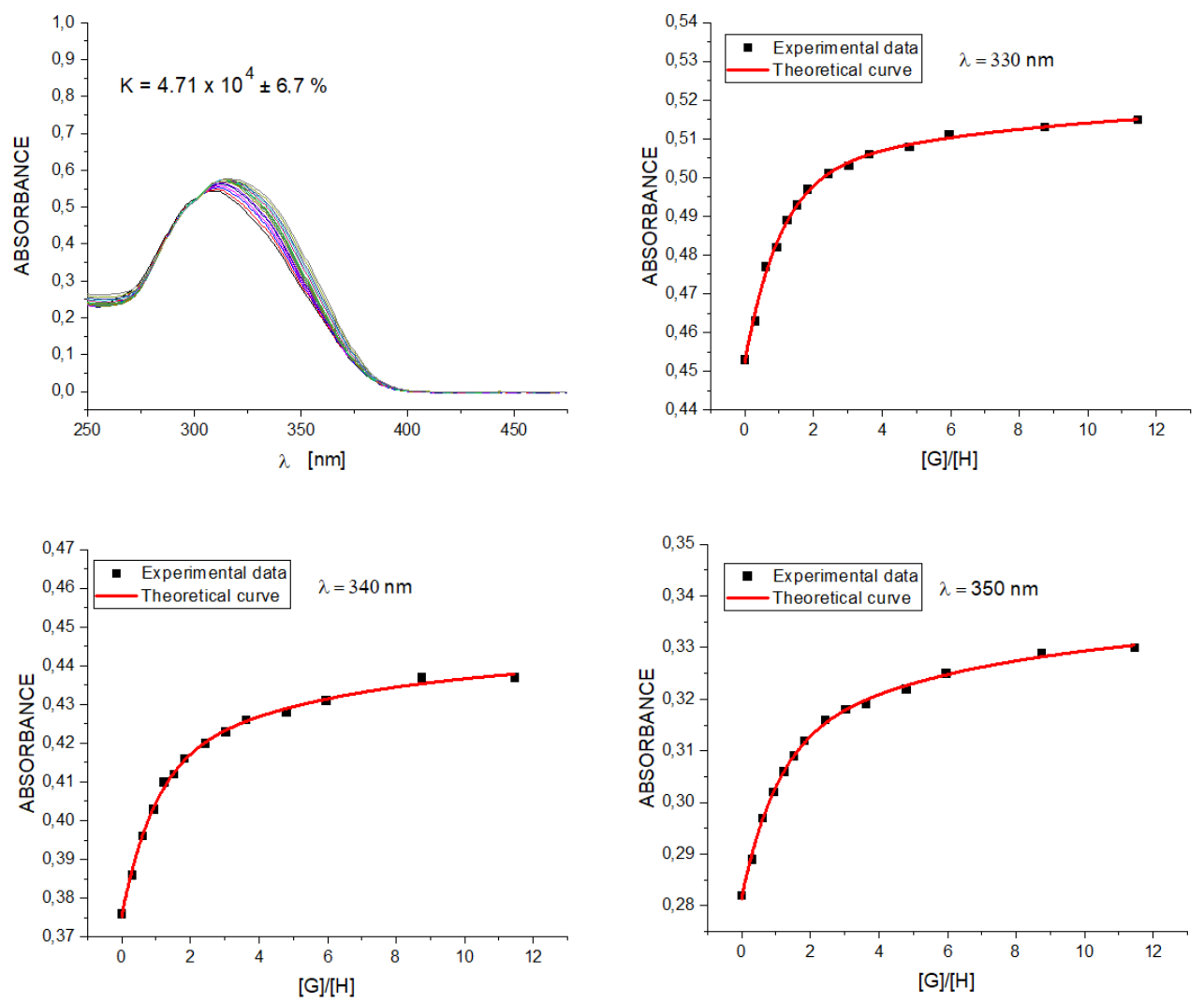

Fig. S43. UV-vis titration of receptor 2 with $\mathrm{KPF}_{6}$ in $\mathrm{CH}_{3} \mathrm{CN}$ and selected binding isotherms. 

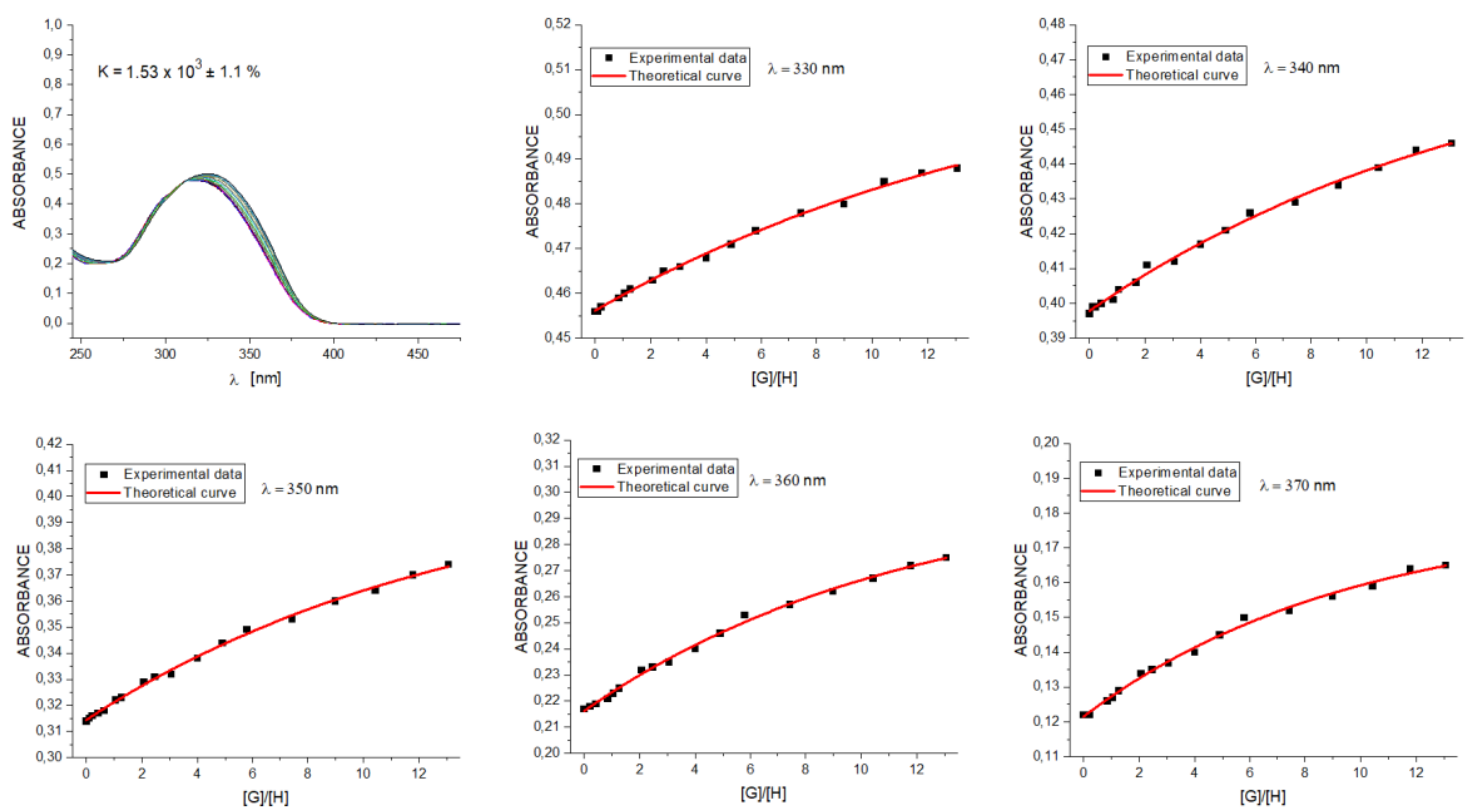

Fig. S44. UV-vis titration of receptor 2 with $\mathrm{TBACl}$ in $5 \% \mathrm{H}_{2} \mathrm{O}\left(\mathrm{pH}=3\right.$ with $\left.\mathrm{HClO}_{4}\right)$ in $\mathrm{CH}_{3} \mathrm{CN}$ and selected binding isotherms.
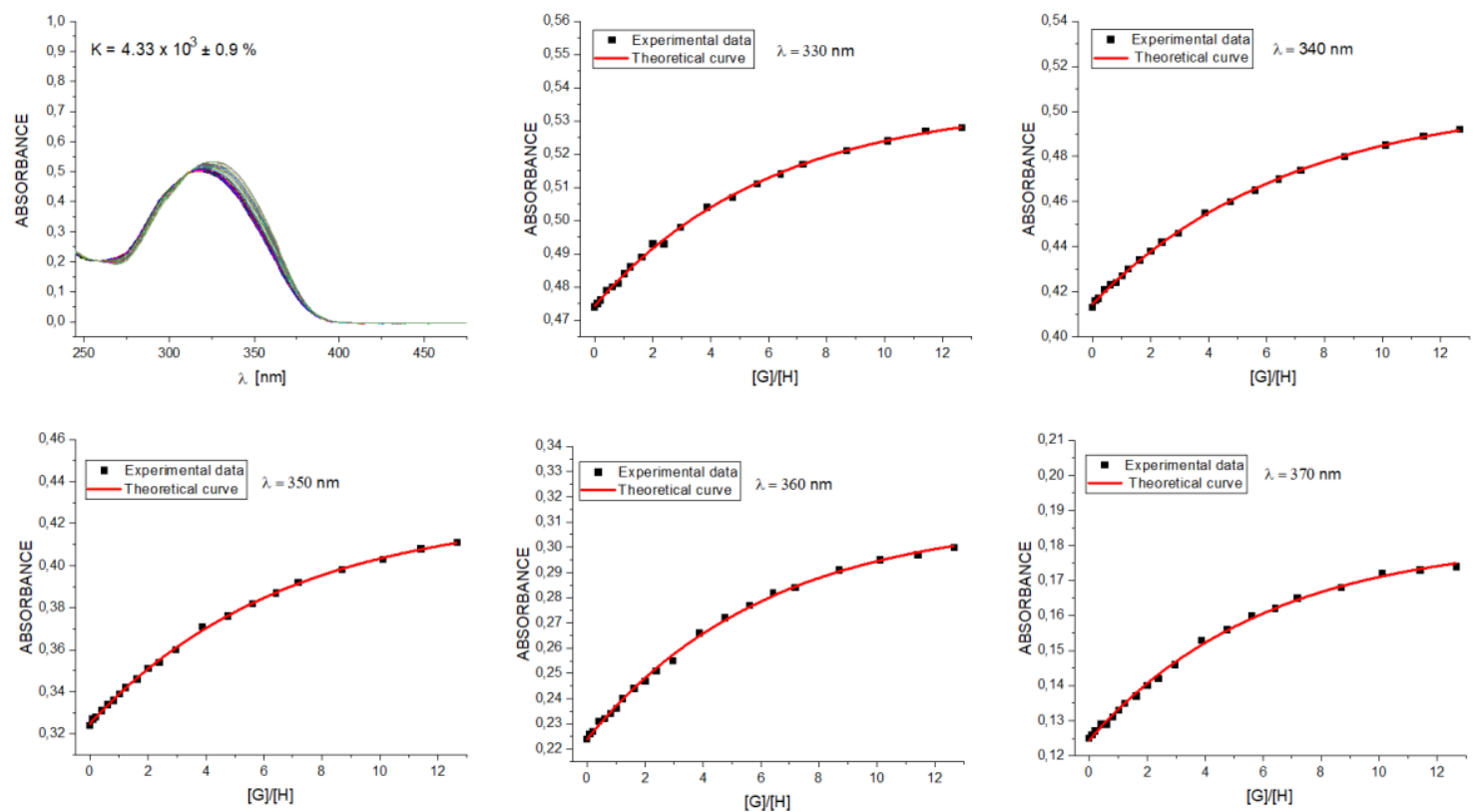

Fig. S45. UV-vis titration of receptor 2 with $\mathrm{NaCl}$ in $5 \% \mathrm{H}_{2} \mathrm{O}\left(\mathrm{pH}=3\right.$ with $\left.\mathrm{HClO}_{4}\right)$ in $\mathrm{CH}_{3} \mathrm{CN}$ and selected binding isotherms. 

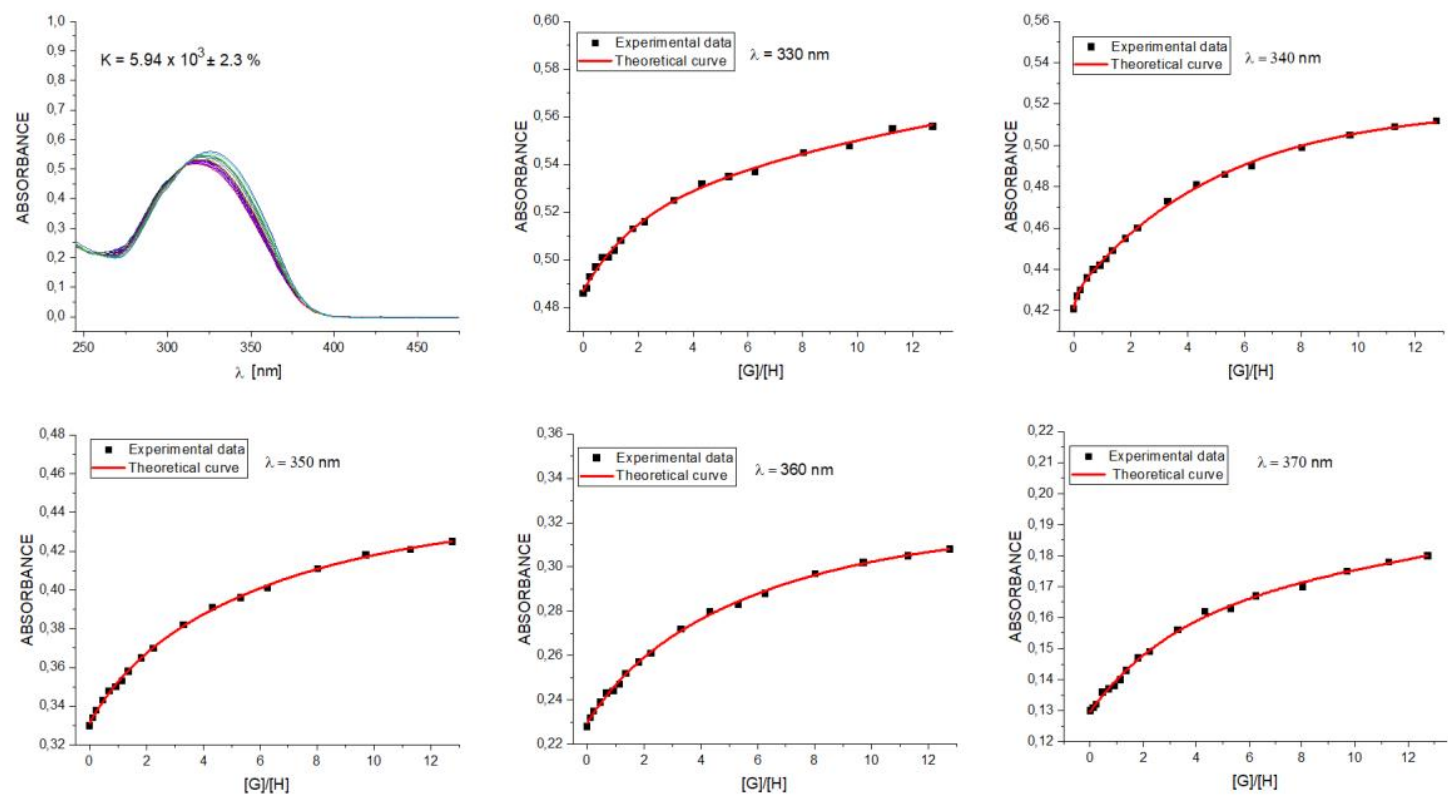

Fig. S46. UV-vis titration of receptor 2 with $\mathrm{KCl}$ in $5 \% \mathrm{H}_{2} \mathrm{O}\left(\mathrm{pH}=3\right.$ with $\left.\mathrm{HClO}_{4}\right)$ in $\mathrm{CH}_{3} \mathrm{CN}$ and selected binding isotherms.
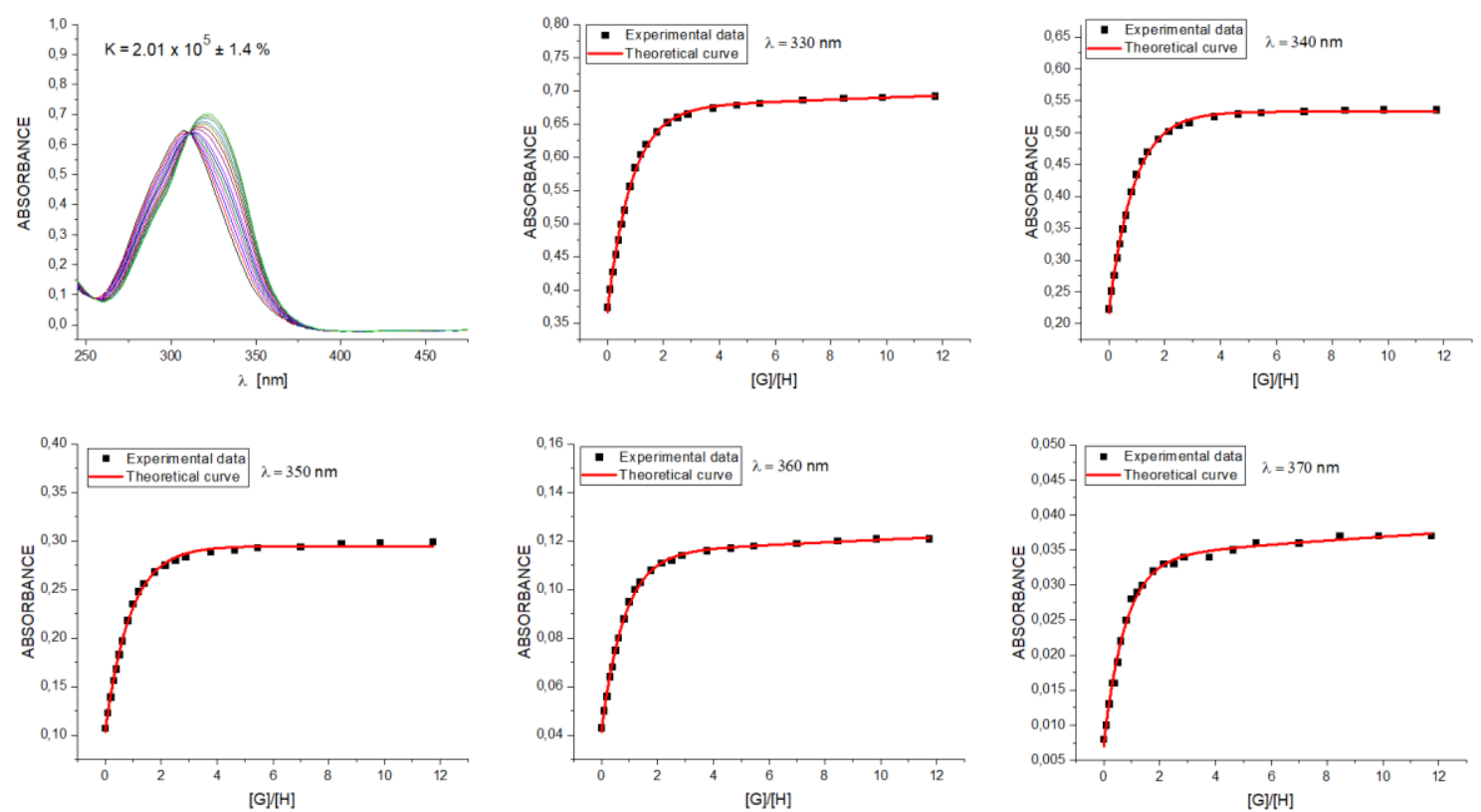

Fig. S47. UV-vis titration of receptor 3 with $\mathrm{TBACl}$ in $\mathrm{CH}_{3} \mathrm{CN}$ and selected binding isotherms. 

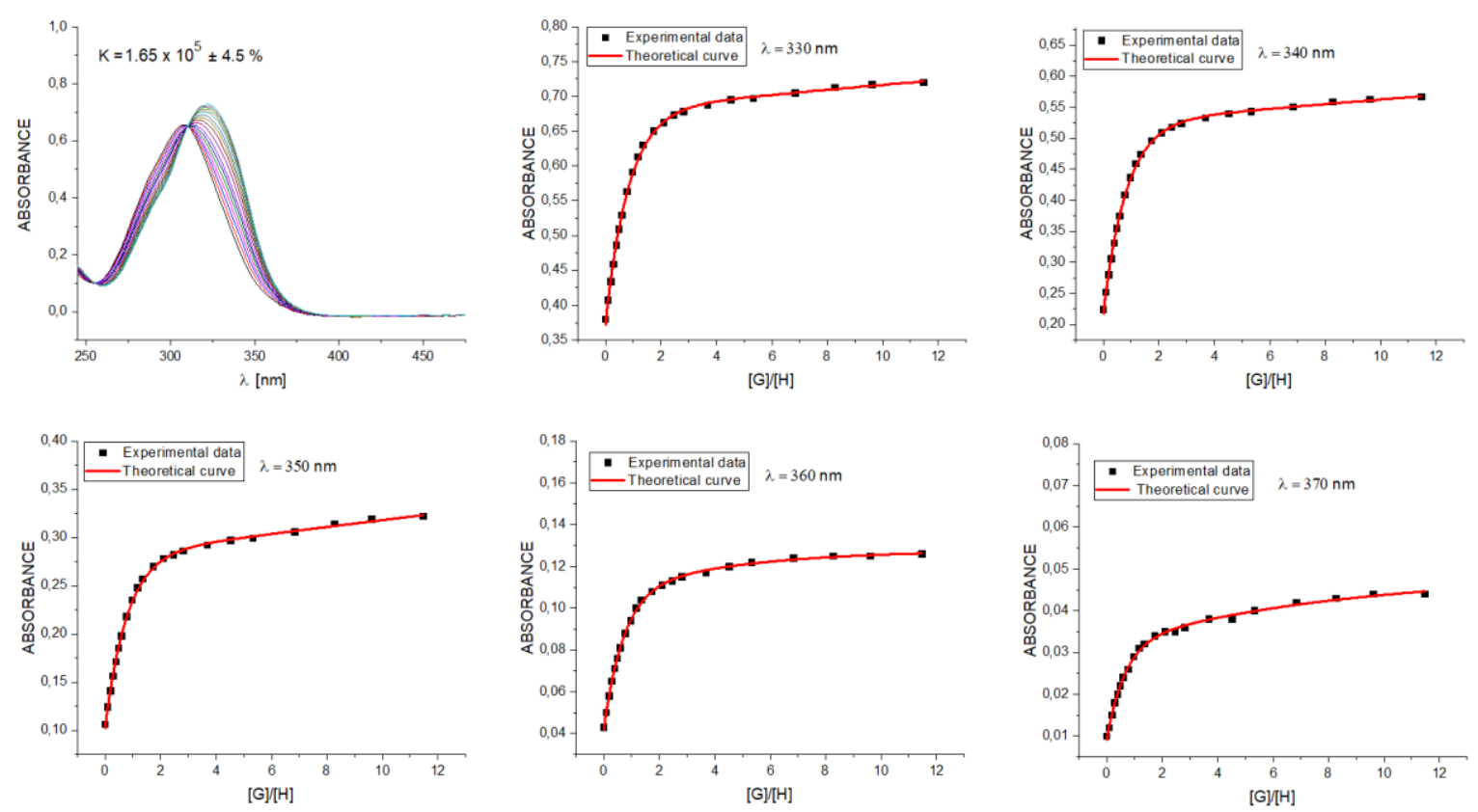

Fig. S48. UV-vis titration of receptor 3 with TBACl in the presence of 1 equivalent of $\mathrm{NaClO}_{4}$ in $\mathrm{CH}_{3} \mathrm{CN}$ and selected binding isotherms.
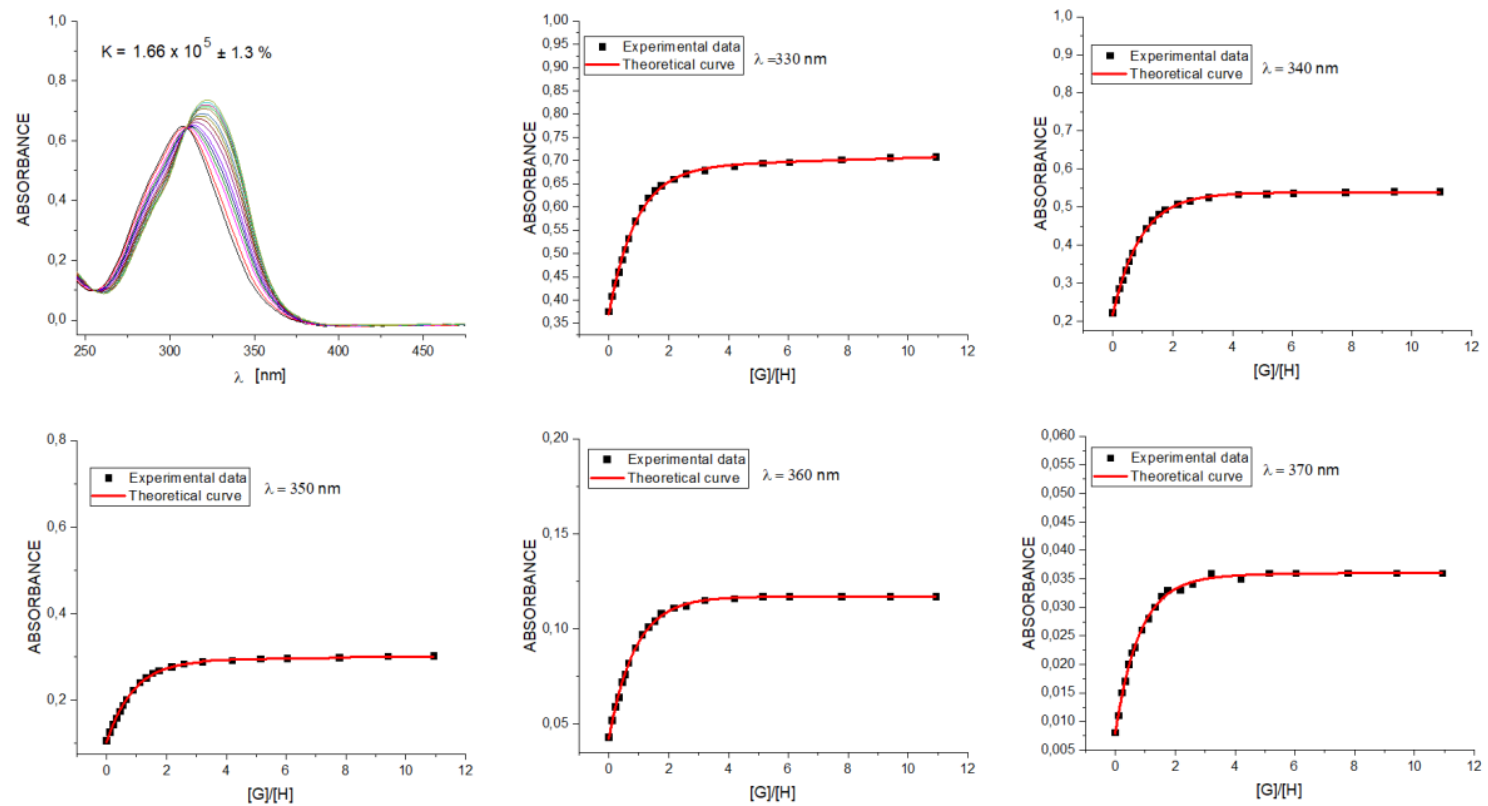

Fig. S49. UV-vis titration of receptor 3 with $\mathrm{TBACl}$ in the presence of 1 equivalent of $\mathrm{KPF}_{6}$ in $\mathrm{CH}_{3} \mathrm{CN}$ and selected binding isotherms. 

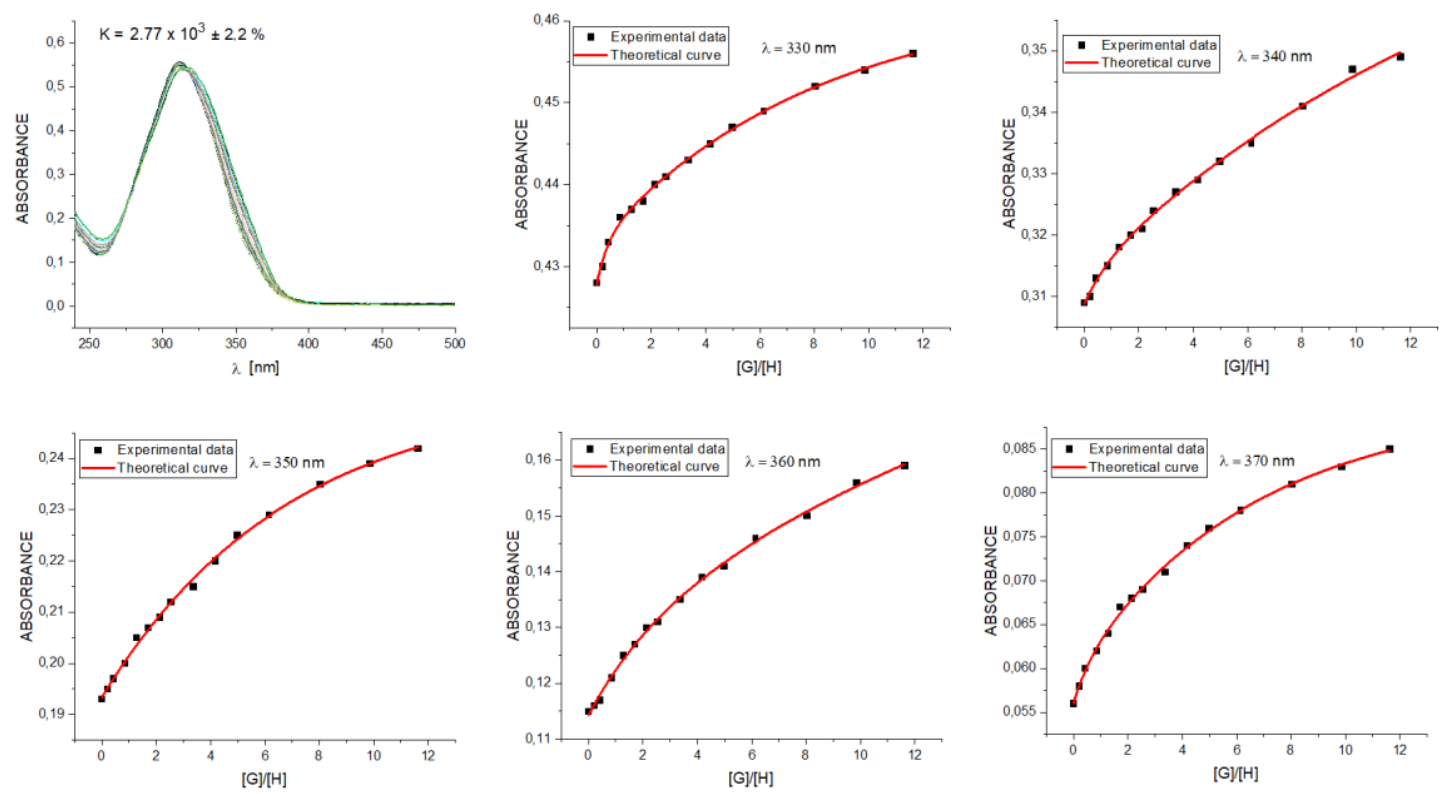

Fig. S50. UV-vis titration of receptor 3 with $\mathrm{TBACl}$ in $5 \% \mathrm{H}_{2} \mathrm{O}\left(\mathrm{pH}=3\right.$ with $\left.\mathrm{HClO}_{4}\right)$ in $\mathrm{CH}_{3} \mathrm{CN}$ and selected binding isotherms.
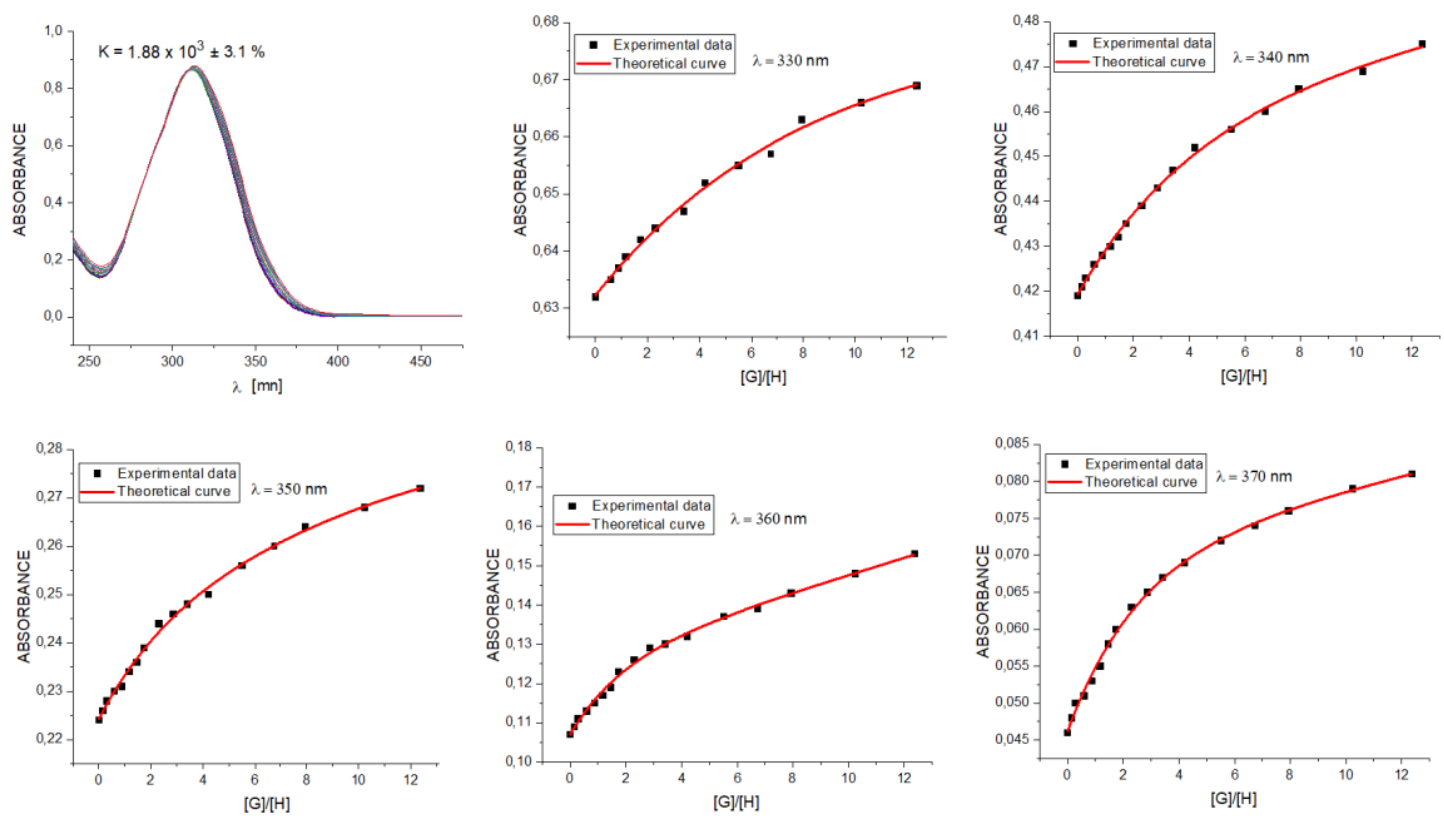

Fig. S51. UV-vis titration of receptor 3 with $\mathrm{NaCl}$ in $5 \% \mathrm{H}_{2} \mathrm{O}\left(\mathrm{pH}=3\right.$ with $\left.\mathrm{HClO}_{4}\right)$ in $\mathrm{CH}_{3} \mathrm{CN}$ and selected binding isotherms. 


\section{NMR Titration}

The ${ }^{1} \mathrm{H}$ NMR titration was performed on a Bruker 300 spectrometer, at $298 \mathrm{~K}$ in $\mathrm{CD}_{3} \mathrm{CN}$. In each case, a $500 \mu \mathrm{L}$ of freshly prepared ca. $3 \mathrm{mM}$ solution of receptor was added to a $5 \mathrm{~mm}$ NMR tube. In the case of ion pair titration receptor was firstly pretreated with one equivalent of $\mathrm{NaClO}_{4}$ or $\mathrm{KPF}_{6}$ (refers to receptor). Then small aliquots of solution of TBAX, containing receptor at constant concentration, were added and a spectrum was acquired after each addition. The resulting titration data were analyzed using BindFit (v0.5) package, available online at http://supramolecular.org.

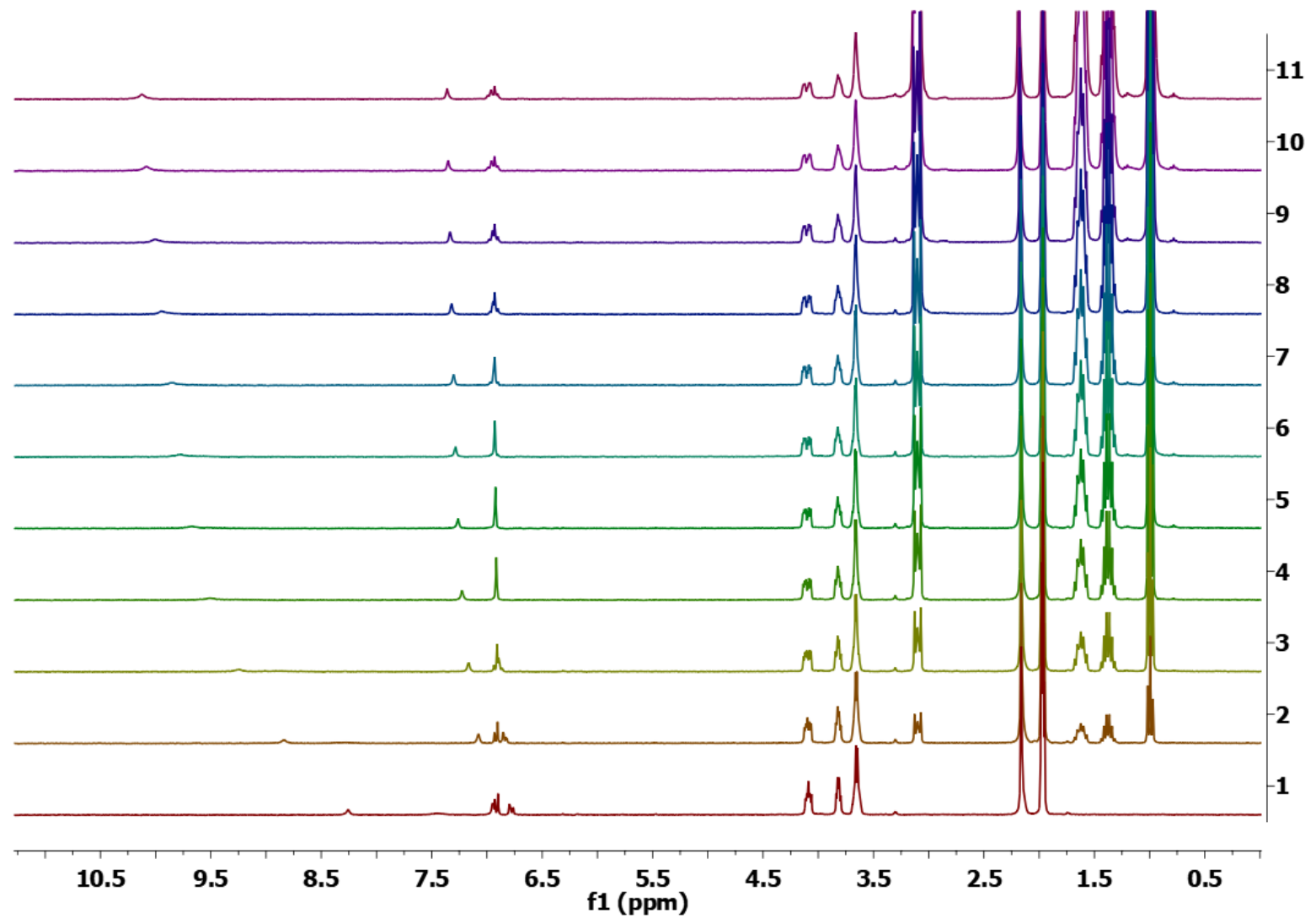

Fig. S52. Typical ${ }^{1} \mathrm{H}$ NMR spectra recorded upon titration of receptor 1 in $\mathrm{CD}_{3} \mathrm{CN}$ with $\mathrm{TBABr}$. 


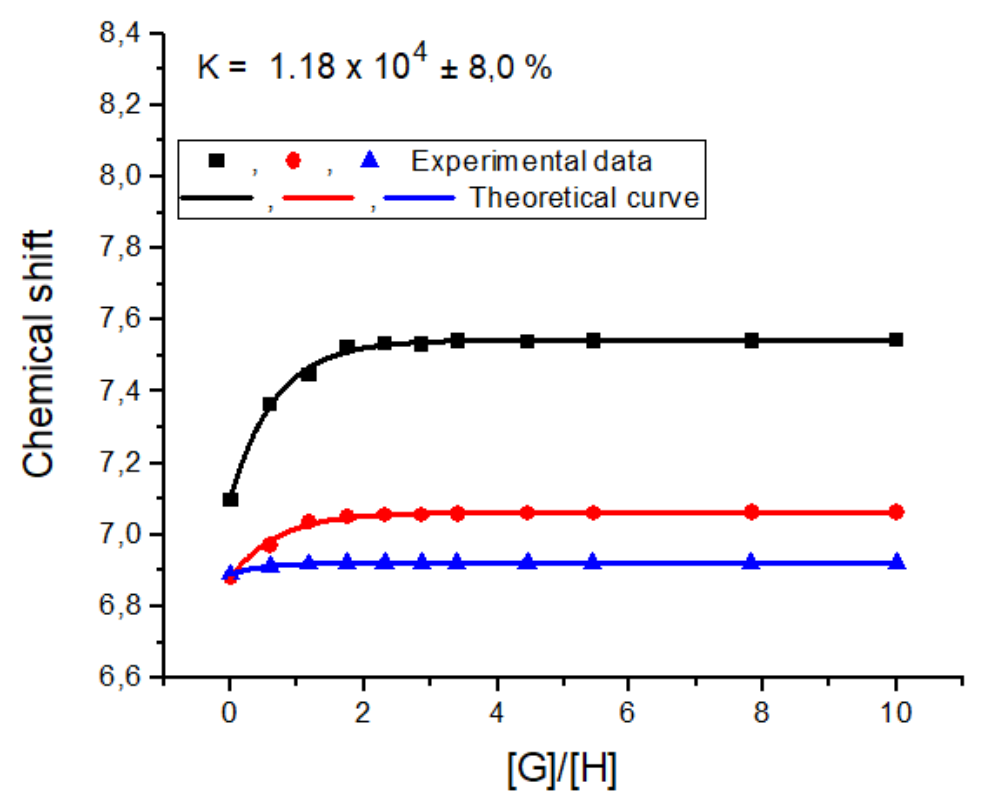

Fig. S53. ${ }^{1} \mathrm{H}$ NMR titration binding isotherms of receptor $1(3.0 \mathrm{mM})$ in $\mathrm{CD}_{3} \mathrm{CN}$ upon addition of increasing amounts of TBABr.

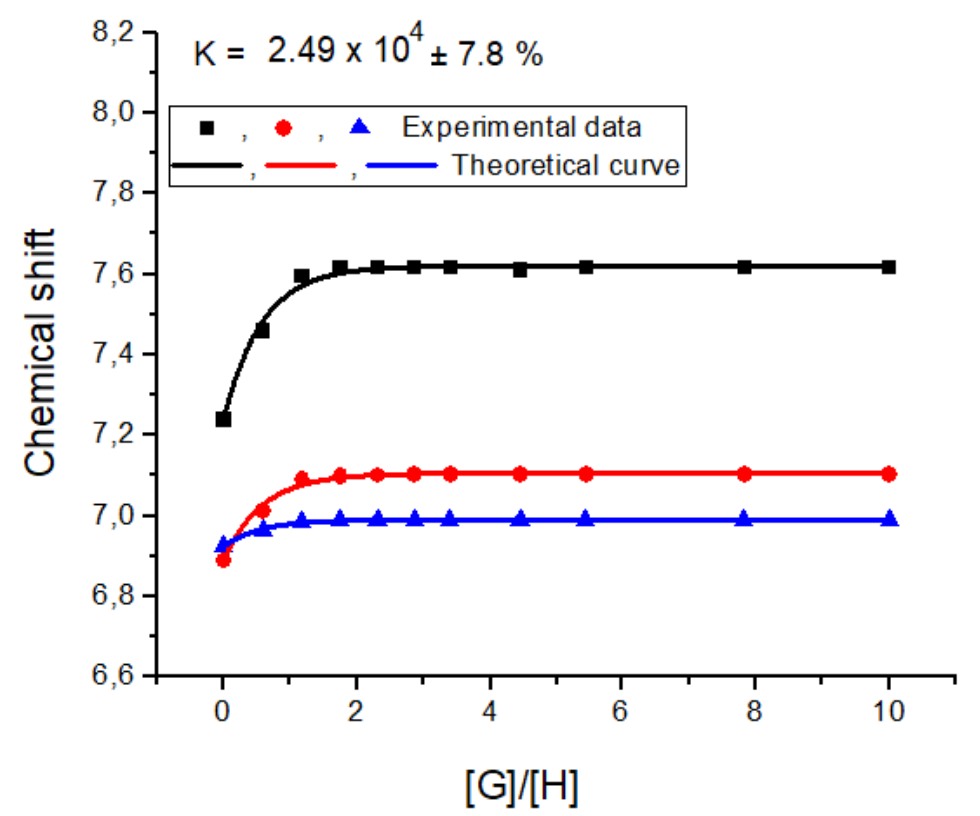

Fig. S54. ${ }^{1} \mathrm{HNMR}$ titration binding isotherms of receptor $1(3.0 \mathrm{mM})$ in $\mathrm{CD}_{3} \mathrm{CN}$ upon addition of increasing amounts of $\mathrm{TBABr}$ in the presence of 1 eq. $\mathrm{NaClO}_{4}$. 

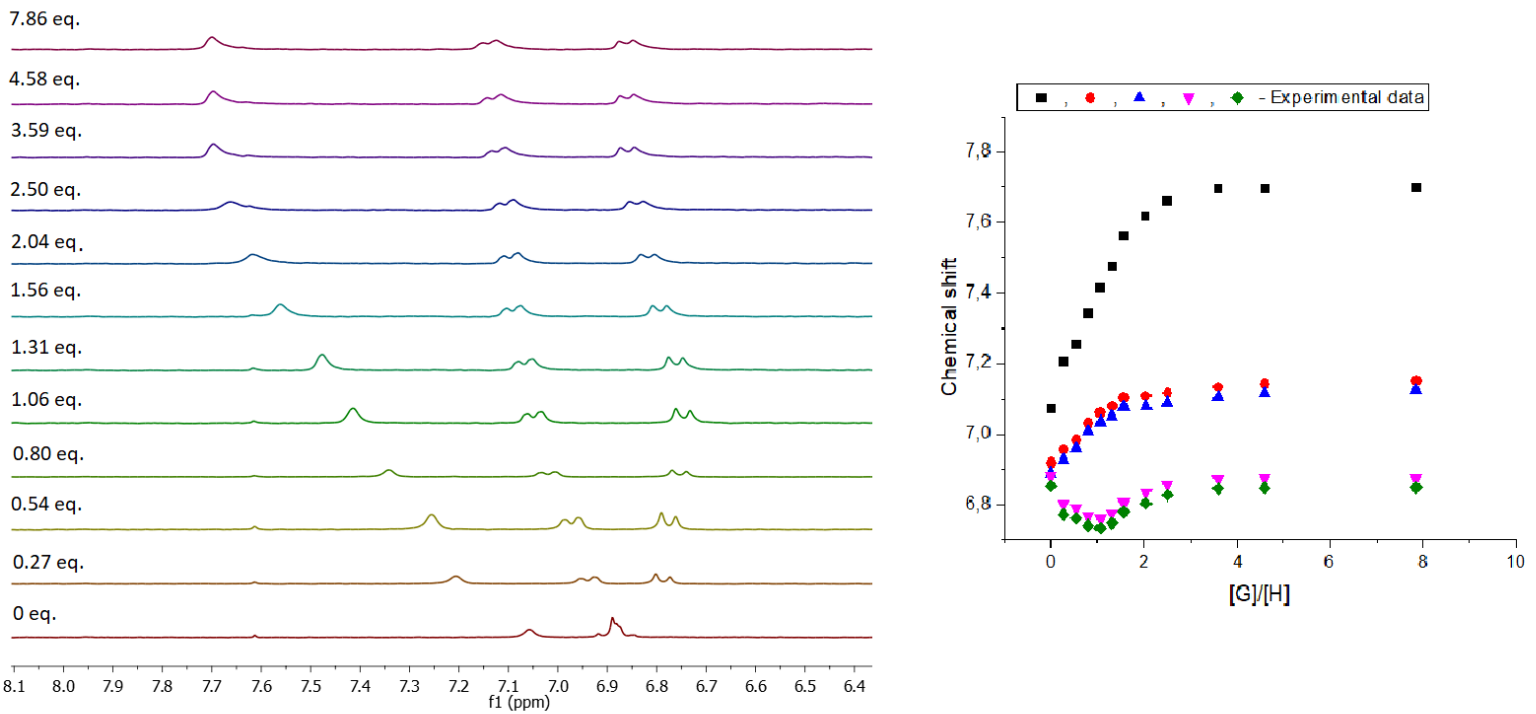

Fig55. Partial ${ }^{1} \mathrm{HNMR}$ spectra recorded upon titration of receptor $1(3.4 \mathrm{mM})$ in $\mathrm{CD}_{3} \mathrm{CN}$ with $\mathrm{TBA}_{2} \mathrm{SO}_{4}$ (signals corresponding to phenyl protons) and binding isotherms.
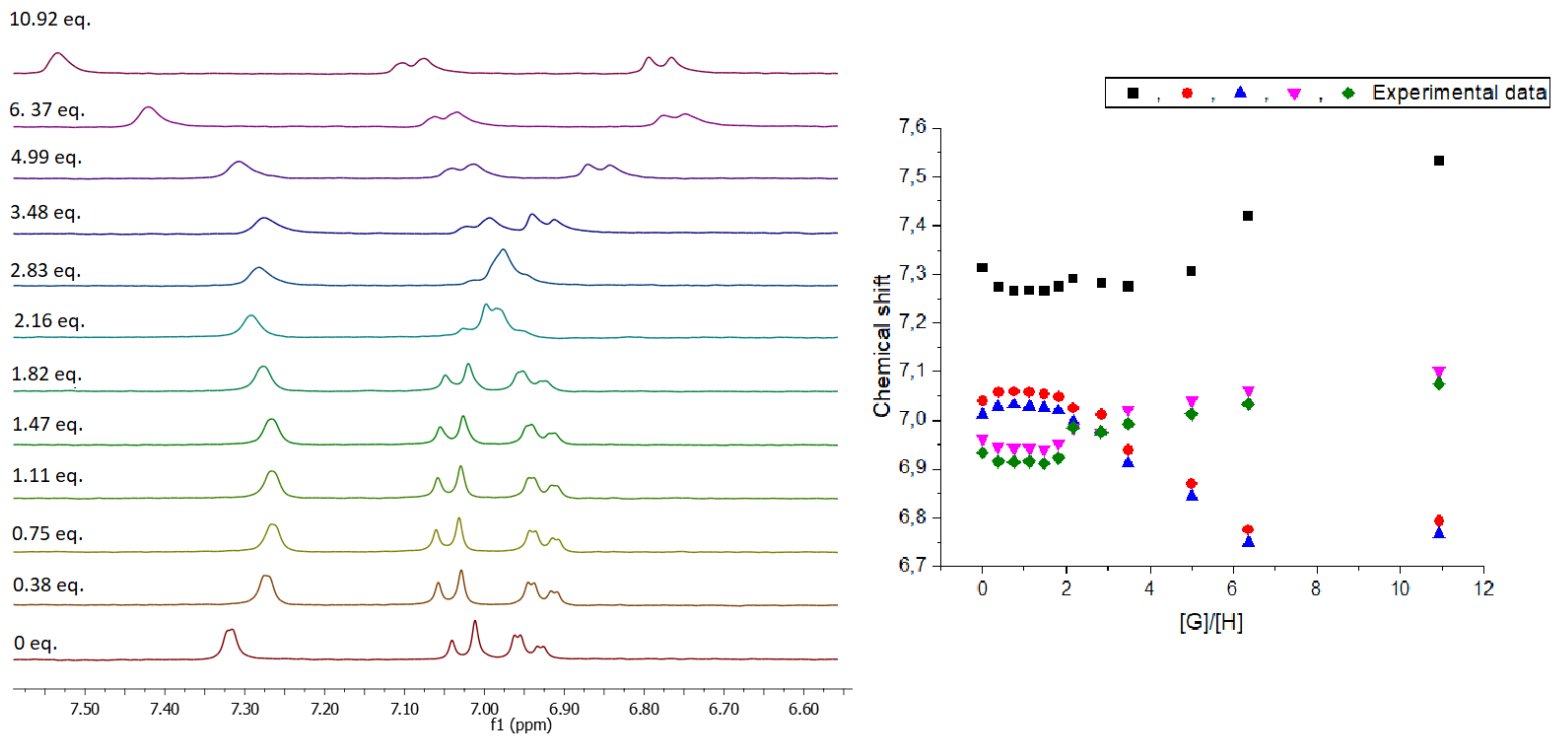

Fig. S56. Partial ${ }^{1} \mathrm{HNMR}$ spectra recorded upon titration of receptor $1(3.4 \mathrm{mM})$ in $\mathrm{CD}_{3} \mathrm{CN}$ with $\mathrm{TBA}_{2} \mathrm{SO}_{4}$ in the presence of 1 equivalent of $\mathrm{NaClO}_{4}$ (signals corresponding to phenyl protons) and binding isotherms. 


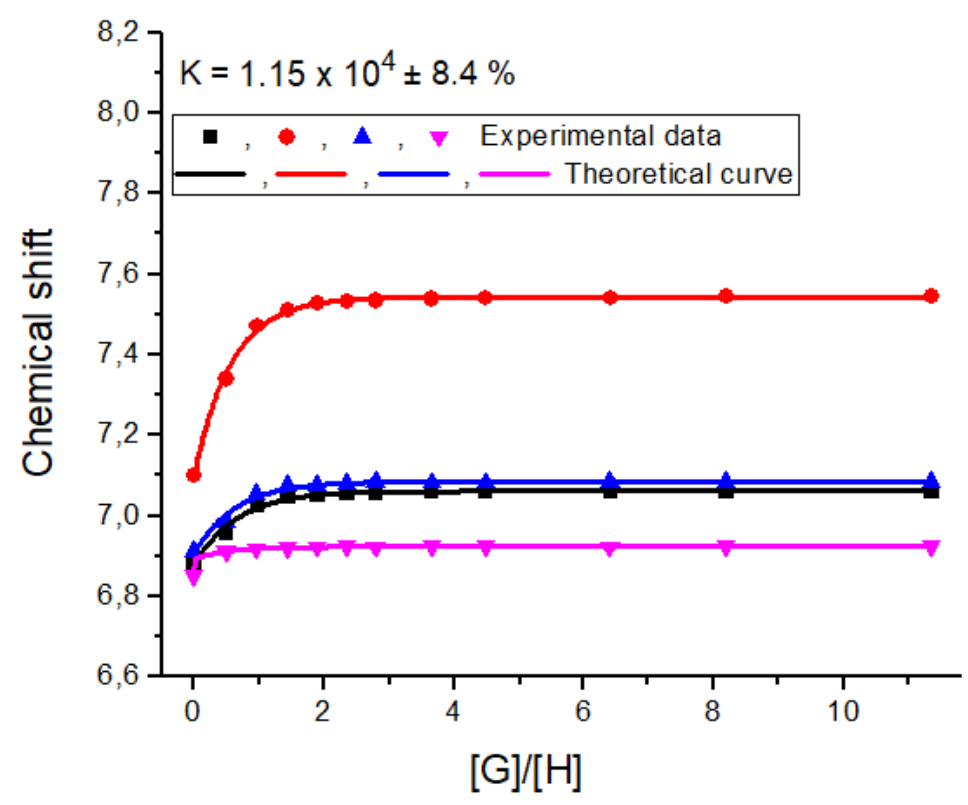

Fig. S57. ${ }^{1} \mathrm{H}$ NMR titration binding isotherms of receptor $2(3.1 \mathrm{mM})$ in $\mathrm{CD}_{3} \mathrm{CN}$ upon addition of increasing amounts of TBABr.

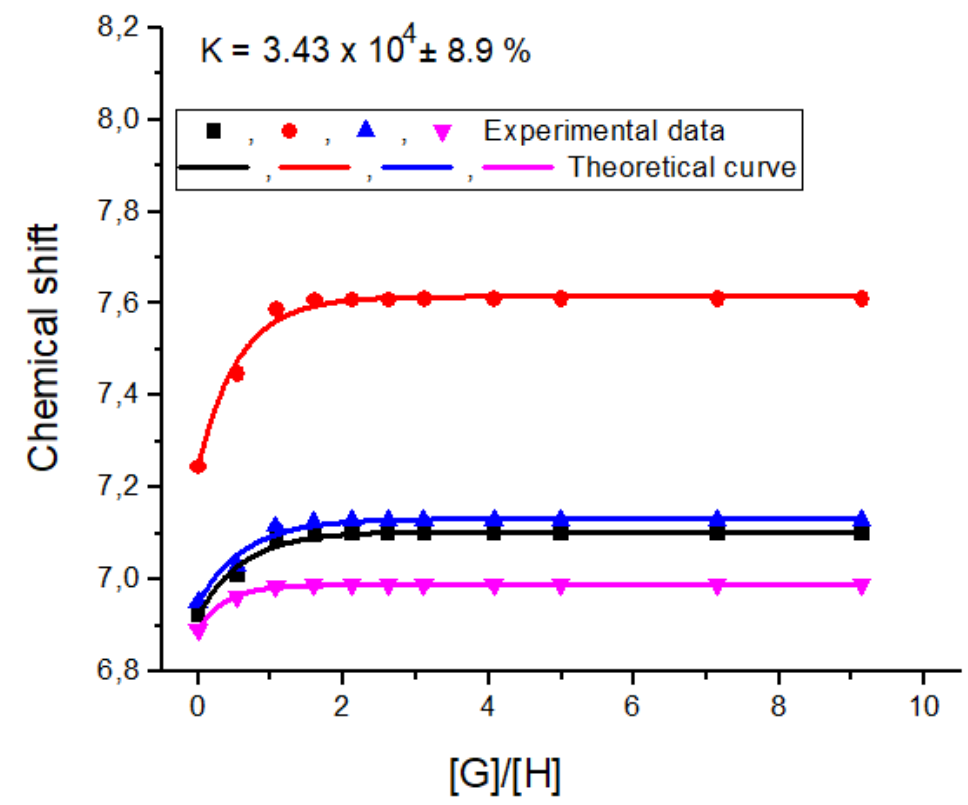

Fig. S58. ${ }^{1} \mathrm{H}$ NMR titration binding isotherms of receptor $2(3.1 \mathrm{mM})$ in $\mathrm{CD}_{3} \mathrm{CN}$ upon addition of increasing amounts of $\mathrm{TBABr}$ in the presence of 1 eq. $\mathrm{KPF}_{6}$. 

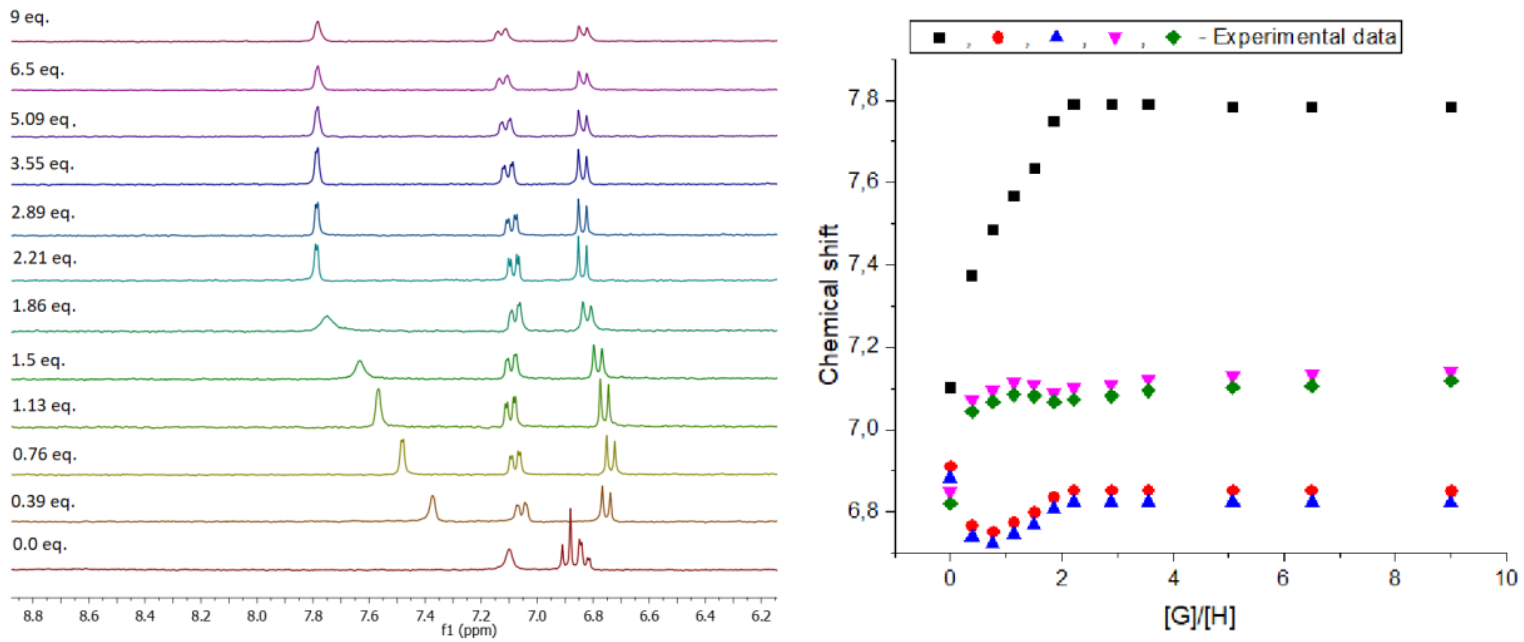

Fig. S59. Partial ${ }^{1} \mathrm{HNMR}$ spectra recorded upon titration of receptor $2(3.0 \mathrm{mM})$ in $\mathrm{CD}_{3} \mathrm{CN}$ with $\mathrm{TBA}_{2} \mathrm{SO}_{4}$ (Signals corresponding to phenyl protons) and binding isotherms.
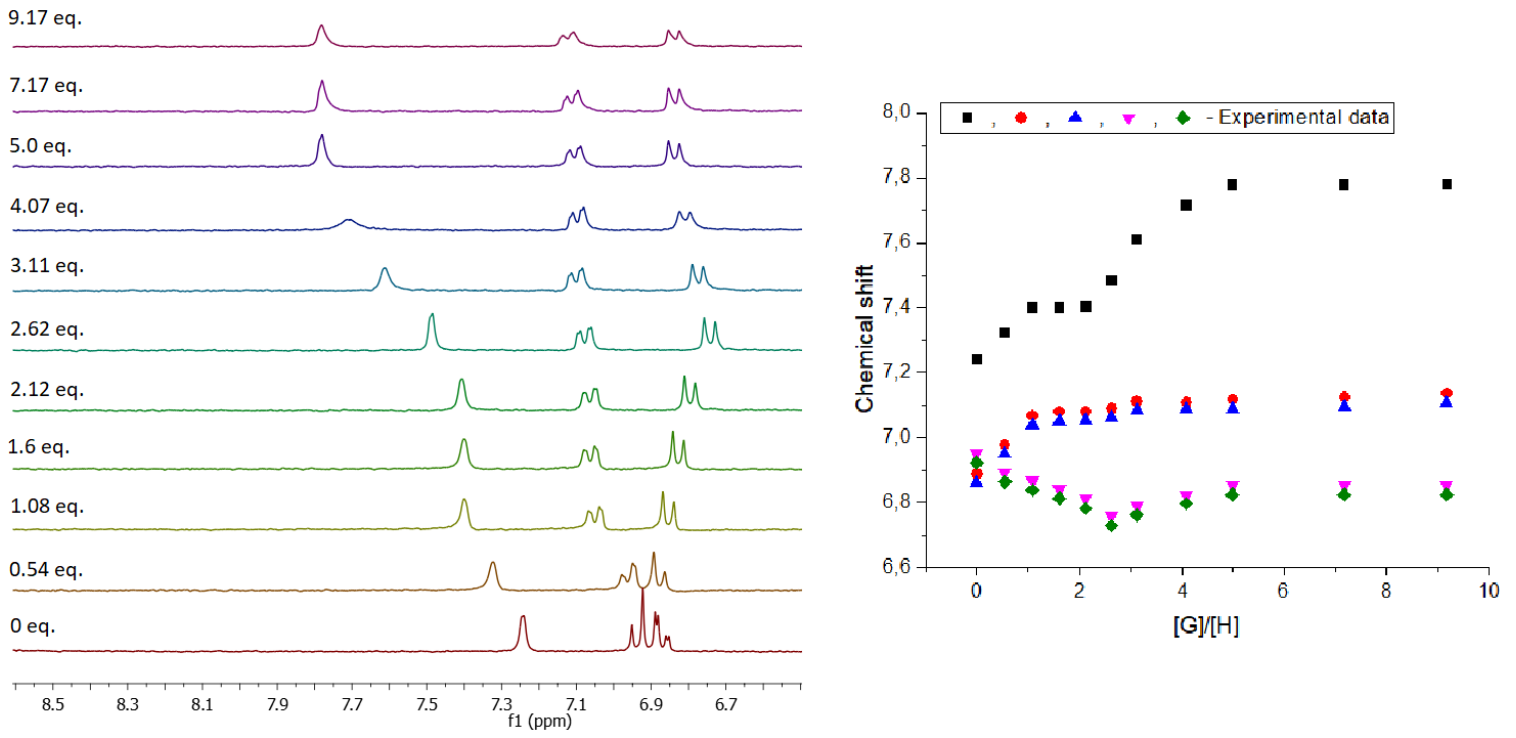

Fig. S60. Partial ${ }^{1} \mathrm{HNMR}$ spectra recorded upon titration of receptor $2(3.0 \mathrm{mM})$ in $\mathrm{CD}_{3} \mathrm{CN}$ with $\mathrm{TBA}_{2} \mathrm{SO}_{4}$ in the presence of 1 equivalent of $\mathrm{KPF}_{6}$ (signals corresponding to phenyl protons) and binding isotherms. 


\section{EXTRACTION EXPERIMENTS - UV-vis}

The ability of receptors $\mathbf{1}$ and $\mathbf{2}$ to extract ions from aqueous solution was qualitatively investigated using a liquid-liquid extraction technique monitored by UV-vis. A solution of receptor 1 or 2 in chloroform $\left(4 \mathrm{ml}, 3 \times 10^{-5} \mathrm{M}\right)$ and $(4 \mathrm{ml}, 50 \mathrm{mM})$ aqueous solution of the appropriate salt were mixed thoroughly for 5 minutes in a vial (prolongation of the extraction time had no effect on the results obtained). The vial was allowed to stand to fully separate the two phases. The organic layer was then separated and screened by UV-vis.

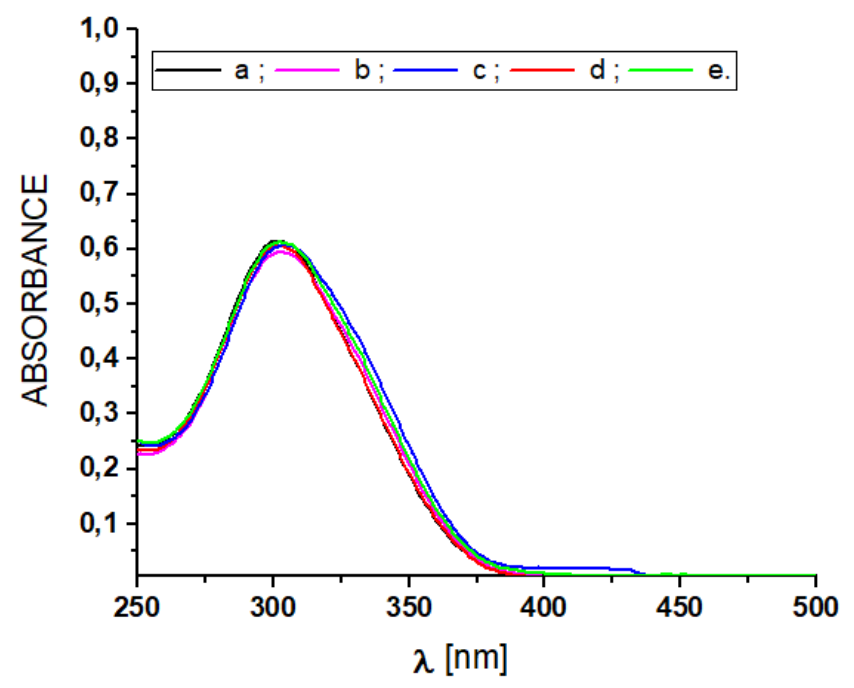

Fig. S61. UV-vis spectra of receptor 1 at $3 \times 10^{-5} \mathrm{M}$ in wet $\mathrm{CDCl}_{3}(\mathbf{a})$, after $\mathrm{NaBr}(50 \mathrm{mM})$ extraction from the aqueous phase (b), after $\mathrm{NaNO}_{3}(50 \mathrm{mM})$ extraction from the aqueous phase (c), after $\mathrm{Na}_{2} \mathrm{SO}_{4}(50 \mathrm{mM})$ extraction from the aqueous phase $(\mathbf{d})$, and after $\mathrm{NaCl}(50 \mathrm{mM})$ extraction from the aqueous phase (e). 


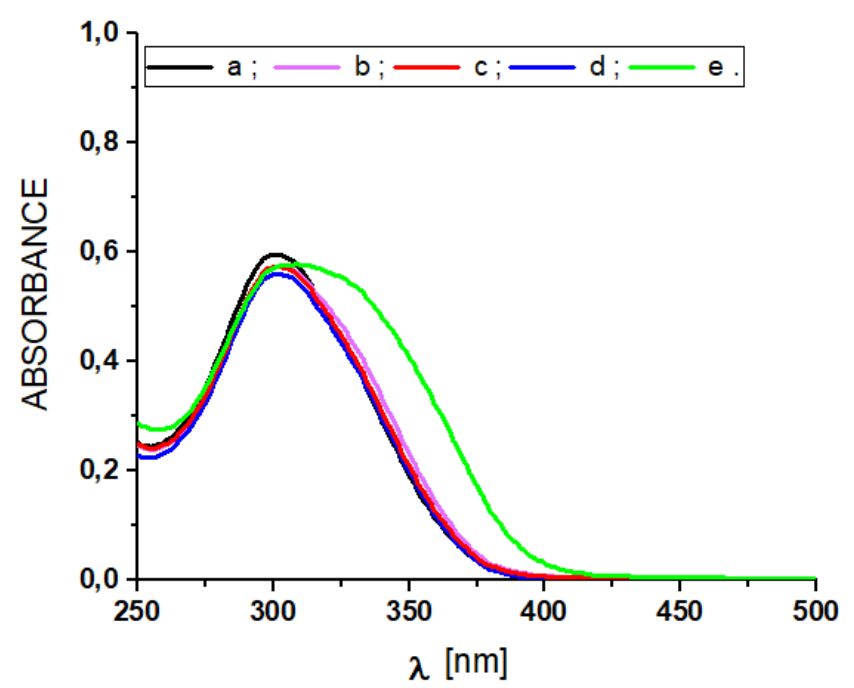

Fig. S62. UV-vis spectra of receptor 2 at $3 \times 10^{-5} \mathrm{M}$ in wet $\mathrm{CDCl}_{3}$ (a), after $\mathrm{NaBr}(50 \mathrm{mM})$ extraction from the aqueous phase (b), after $\mathrm{NaNO}_{3}(50 \mathrm{mM})$ extraction from the aqueous phase (c), after $\mathrm{Na}_{2} \mathrm{SO}_{4}(50 \mathrm{mM})$ extraction from the aqueous phase (d), and after $\mathrm{NaCl}(50 \mathrm{mM})$ extraction from the aqueous phase (e).

\section{EXTRACTION EXPERIMENTS - ATOMIC EMISSION SPECTROSCOPY}

General procedure: A solution of receptor 2 in chloroform $(1 \mathrm{ml}, 1 \mathrm{mM})$ and $0.5 \mathrm{M}$ aqueous solution of the appropriate potassium salt $\left(\mathrm{KCl}, \mathrm{KBr}, \mathrm{KI}, \mathrm{KNO}_{2}, \mathrm{KNO}_{3}, \mathrm{~K}_{2} \mathrm{SO}_{4}, \mathrm{KHSO}_{4}\right)$ were mixed thoroughly for 5 minutes in a vial (prolongation of the extraction time had no effect on the results obtained). The vial was allowed to stand to fully separate the two phases. Then 0.5 $\mathrm{mL}$ of organic phase was taken and diluted to $5 \mathrm{~mL}$ with ethyl acetate. The potassium concentration in organic phase was determined by atomic emission spectroscopy (AES). 
Table S1. Results of potassium extraction experiments.

\begin{tabular}{ccc}
\hline Receptor $\mathbf{2}[\mathbf{1} \mathbf{~ m M}]$ & $\mathbf{C}_{\mathbf{K}}{ }^{+}[\mathbf{m g} / \mathbf{L}]^{\mathbf{a}}$ & $\begin{array}{c}\text { Extraction efficiency/ } \\
\text { Receptor occupation [\%] }\end{array}$ \\
\hline $\begin{array}{c}\text { Extraction from aq. solution } \\
\text { of } \mathrm{KCl}\end{array}$ & 1.984 & 50.75 \\
\hline $\begin{array}{c}\text { Extraction from aq. solution } \\
\text { of } \mathrm{KBr}\end{array}$ & 2.269 & 58.05 \\
\hline $\begin{array}{c}\text { Extraction from aq. solution } \\
\text { of } \mathrm{KI}\end{array}$ & 2.389 & 61.12 \\
\hline $\begin{array}{c}\text { Extraction from aq. solution } \\
\text { of } \mathrm{KNO}_{2}\end{array}$ & 1.995 & 61.04 \\
\hline $\begin{array}{c}\text { Extraction from aq. solution } \\
\text { of } \mathrm{KNO}_{3}\end{array}$ & 2.462 & 62.98 \\
\hline $\begin{array}{c}\text { Extraction from aq. solution } \\
\text { of } \mathrm{K}_{2} \mathrm{SO}_{4}\end{array}$ & 1.78 & 45.54 \\
\hline $\begin{array}{c}\text { Extraction from aq. solution } \\
\text { of } \mathrm{KHSO}_{4}\end{array}$ & 1.112 & 28.45 \\
\hline
\end{tabular}

${ }^{\text {a }}$ concentration after ten times dilution with ethyl acetate

\section{EXTRACTION EXPERIMENTS - ION CHROMATOGRAPHY}

General procedure: A solution of receptor 2 in chloroform $(2 \mathrm{ml}, 20 \mathrm{mM})$ was intensive shaking with aqueous mixture (no $\mathrm{pH}$ adjustment, $\mathrm{pH}$ depending of the salts used; above $\mathrm{pH} 8$ there is no phase separation probably due to the receptor deprotonation. This eliminates direct use of basic salts such as carboxylates, hydrogen phosphates or phosphates) of suitable salts 5 $\mathrm{mM}$ each $(2 \mathrm{ml})$ for 5 minutes. Then $1 \mathrm{~mL}$ of aqueous phase was taken and tenfold diluted. The concentration of chloride, bromide, nitrite, nitrate, dihydrogenphosphate and sulfate anions in aqueous phase was determined by high performance ion chromatography (HPIC). 


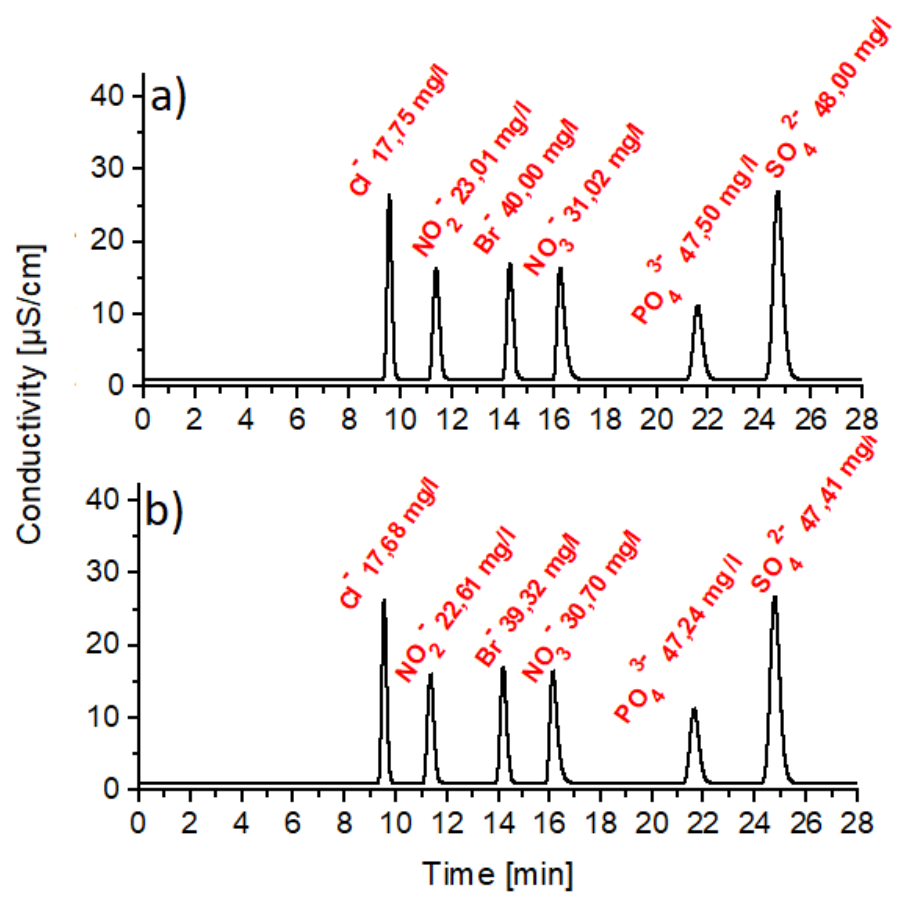

Fig. S63. Chromatograms obtained during extraction experiments after tenfold dilution (a) source phase - aqueous mixture of sodium salts (b) after extraction with $20 \mathrm{mM}$ of receptor 2 in $\mathrm{CHCl}_{3}$.

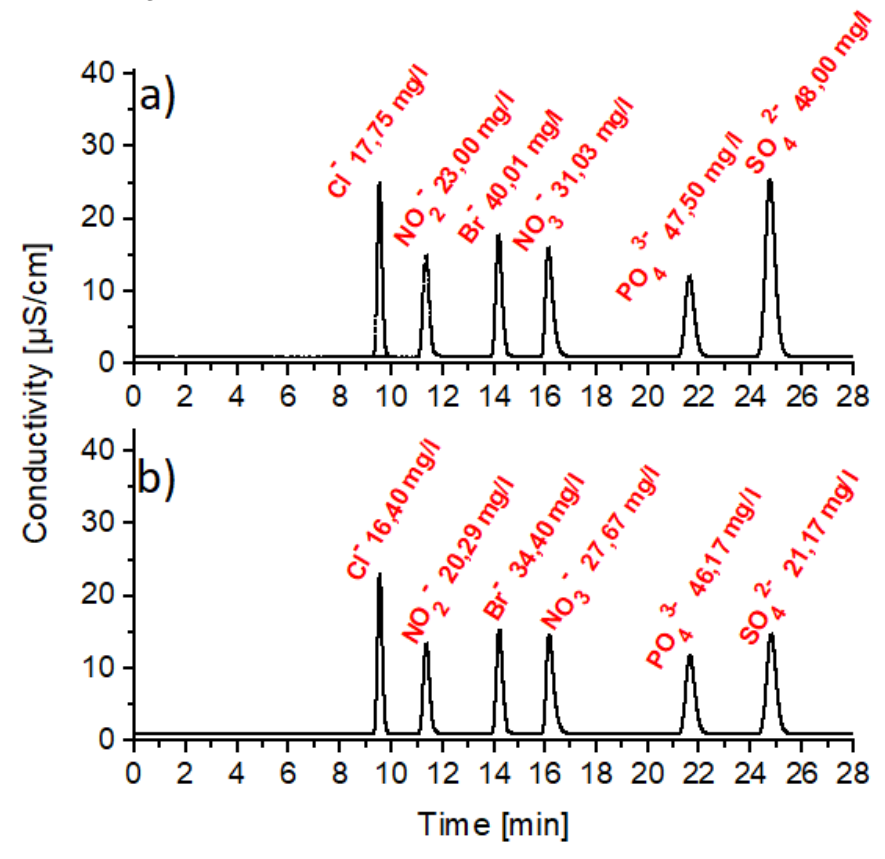

Fig. S64. Chromatograms obtained during extraction experiments after tenfold dilution (a) source phase - aqueous mixture of potassium salts (b) after extraction with $20 \mathrm{mM}$ of receptor 2 in $\mathrm{CHCl}_{3}$. 


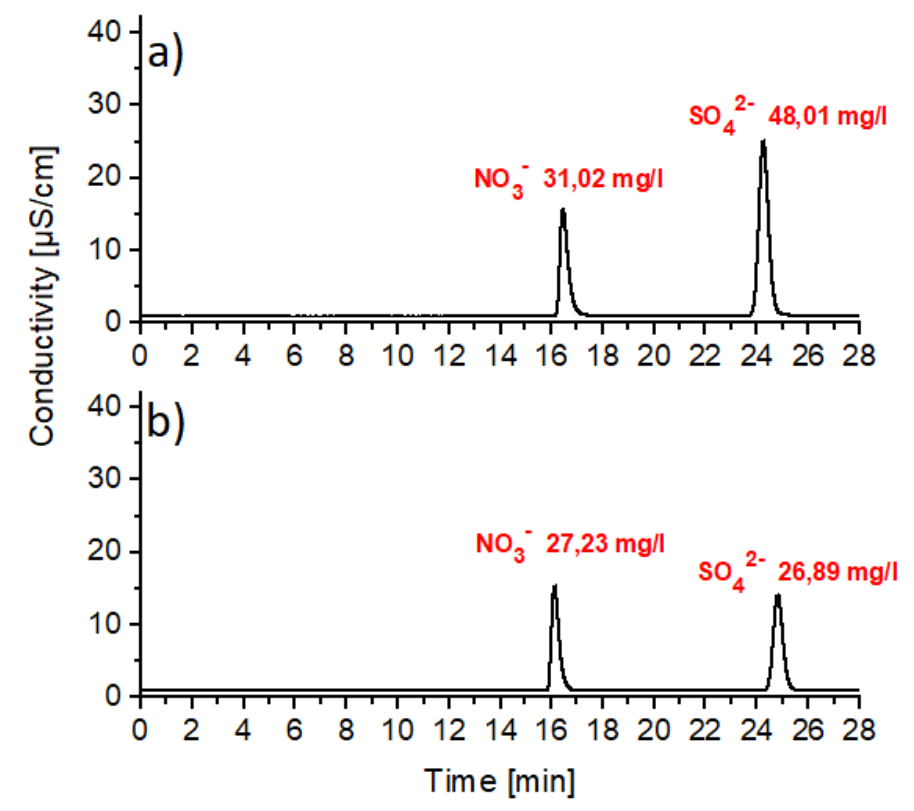

Fig. S65. Chromatograms obtained during extraction experiments after tenfold dilution (a) source phase - aqueous mixture of $\mathrm{KNO}_{3}$ and $\mathrm{K}_{2} \mathrm{SO}_{4}$ salts (b) after extraction with $20 \mathrm{mM}$ of receptor 2 in $\mathrm{CHCl}_{3}$.

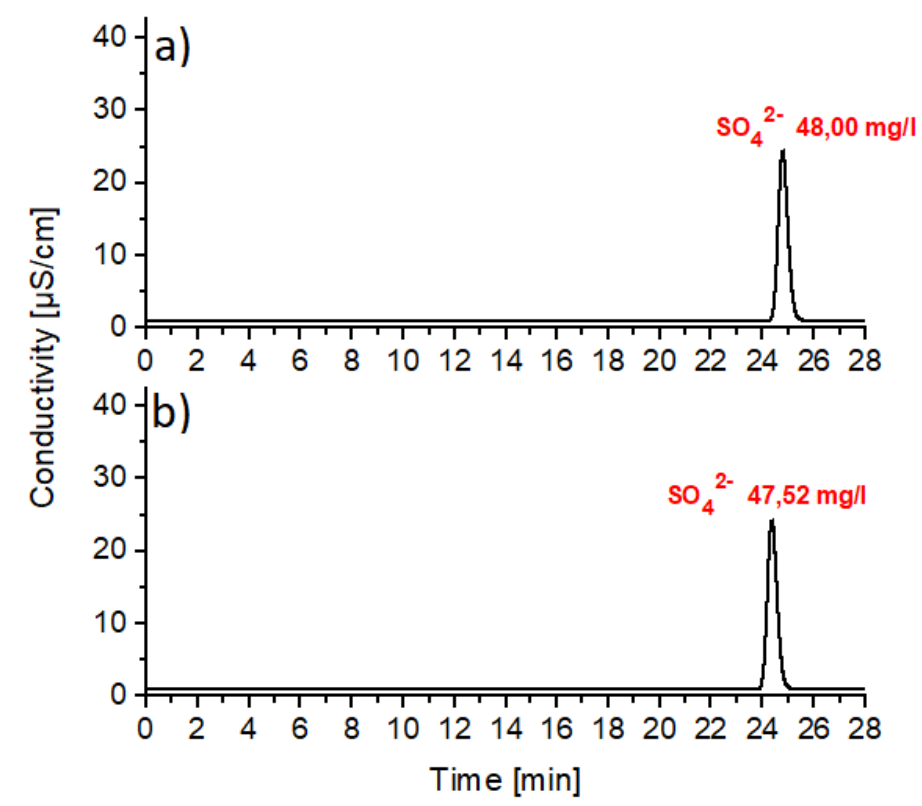

Fig. S66. Chromatogram obtained during extraction experiment after tenfold dilution (a) source phase - aqueous $\mathrm{Na}_{2} \mathrm{SO}_{4}$ salt (b) after extraction with $20 \mathrm{mM}$ of receptor 2 in $\mathrm{CHCl}_{3}$. 


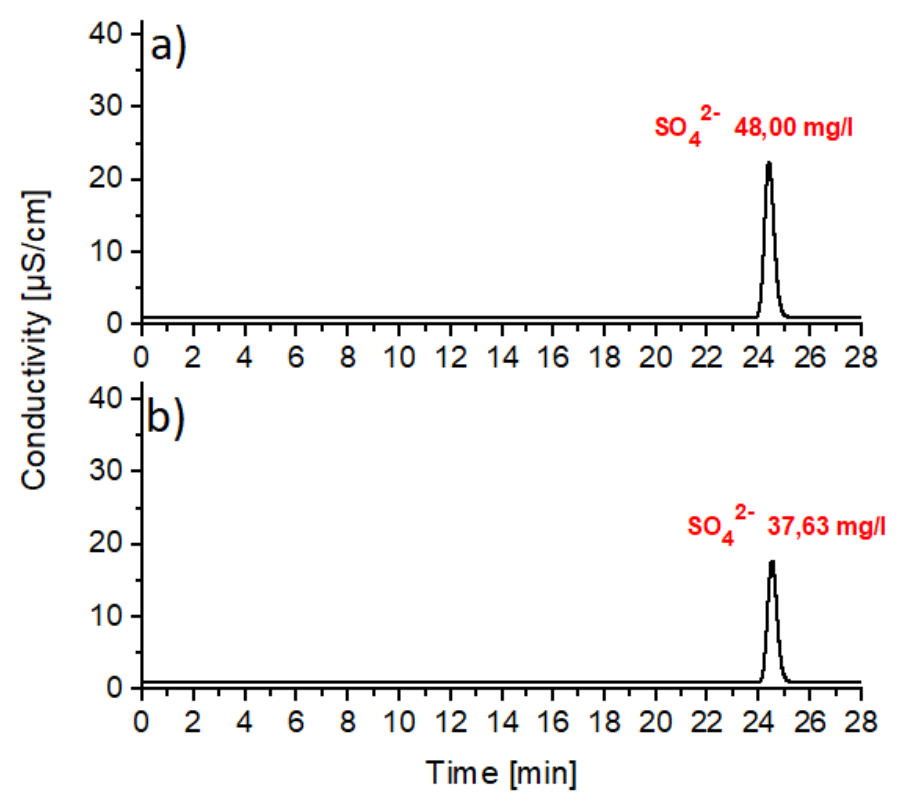

Fig. S67. Chromatogram obtained during extraction experiment after tenfold dilution (a) source phase - aqueous $\mathrm{TBA}_{2} \mathrm{SO}_{4}$ salt (b) after extraction with $20 \mathrm{mM}$ of receptor 2 in $\mathrm{CHCl}_{3}$.

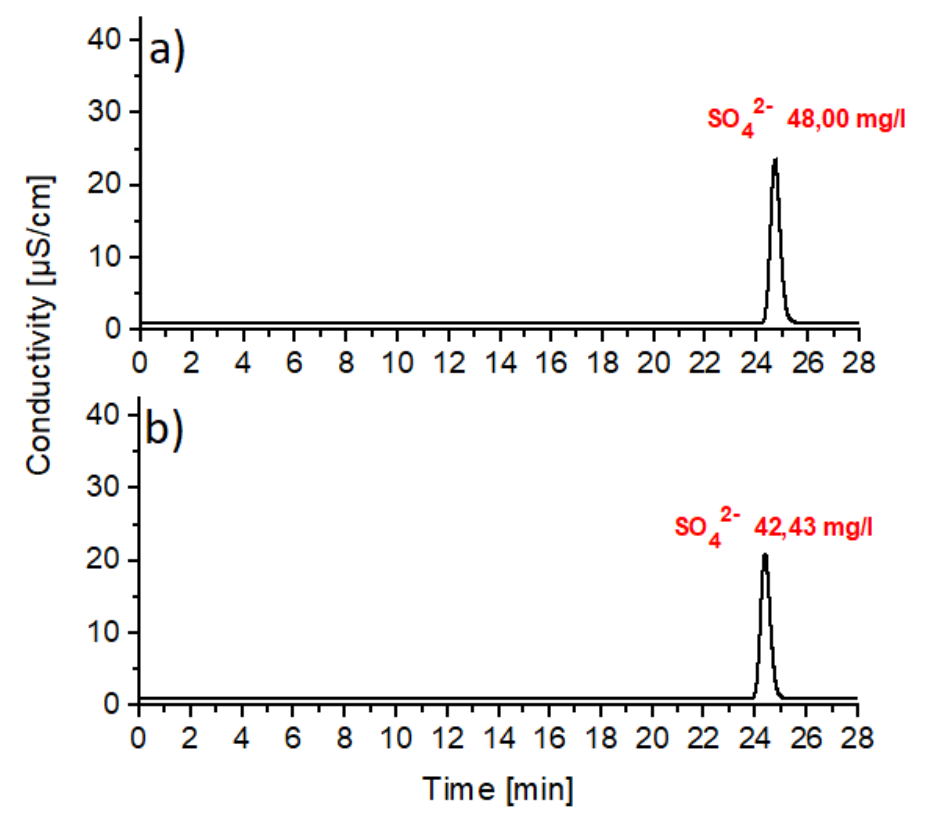

Fig. S68. Chromatograms obtained during extraction experiments after tenfold dilution (a) source phase - aqueous mixture of $\mathrm{TBA}_{2} \mathrm{SO}_{4}$ and $\mathrm{Na}_{2} \mathrm{SO}_{4}$ salts (b) after extraction with $20 \mathrm{mM}$ of receptor 2 in $\mathrm{CHCl}_{3}$. 


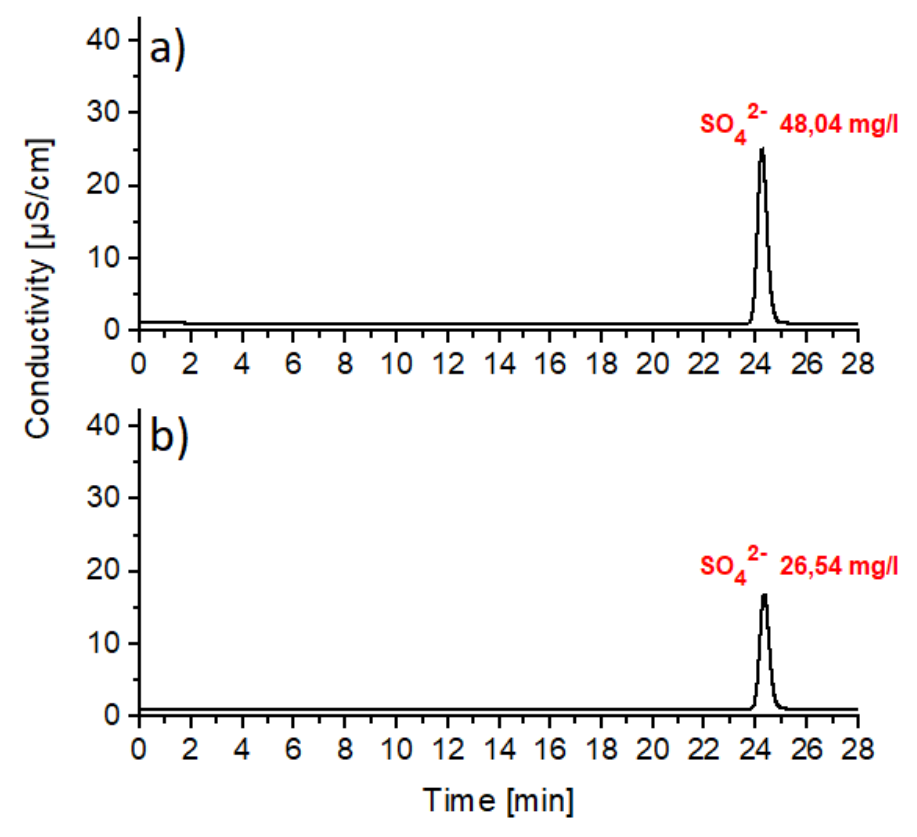

Fig. S69. Chromatogram obtained during extraction experiment after tenfold dilution (a) source phase - aqueous $\mathrm{K}_{2} \mathrm{SO}_{4}$ salt (b) after extraction with $20 \mathrm{mM}$ of receptor 2 in $\mathrm{CHCl}_{3}$.

\section{Dynamic Light Scattering (DLS)}

The changes in the size of the receptor $\mathbf{2}$ and supramolecular complexes formed in wet chloroform after extraction were also performed in means of DLS measurements. The value of the solvodynamic diameter was found to be circa $1.2 \mathrm{~nm}$ for receptor $2(1 \mathrm{mM})$ in wet chloroform and after extraction with aqueous solution of $\mathrm{KBr}$ or $\mathrm{K}_{2} \mathrm{SO}_{4}$ increased to circa 1.4 or $2.0 \mathrm{~nm}$, respectively.

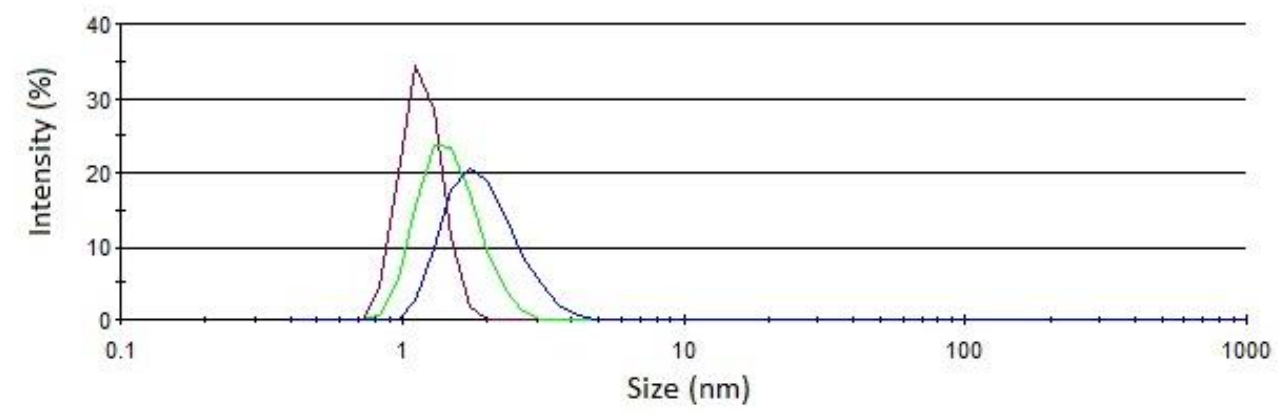

Fig. S70. Diameter distributions of receptor 2 in wet chloroform (brown line), after extraction with aqueous solution of $\mathrm{KBr}$ (green line) and $\mathrm{K}_{2} \mathrm{SO}_{4}$ (blue line). 


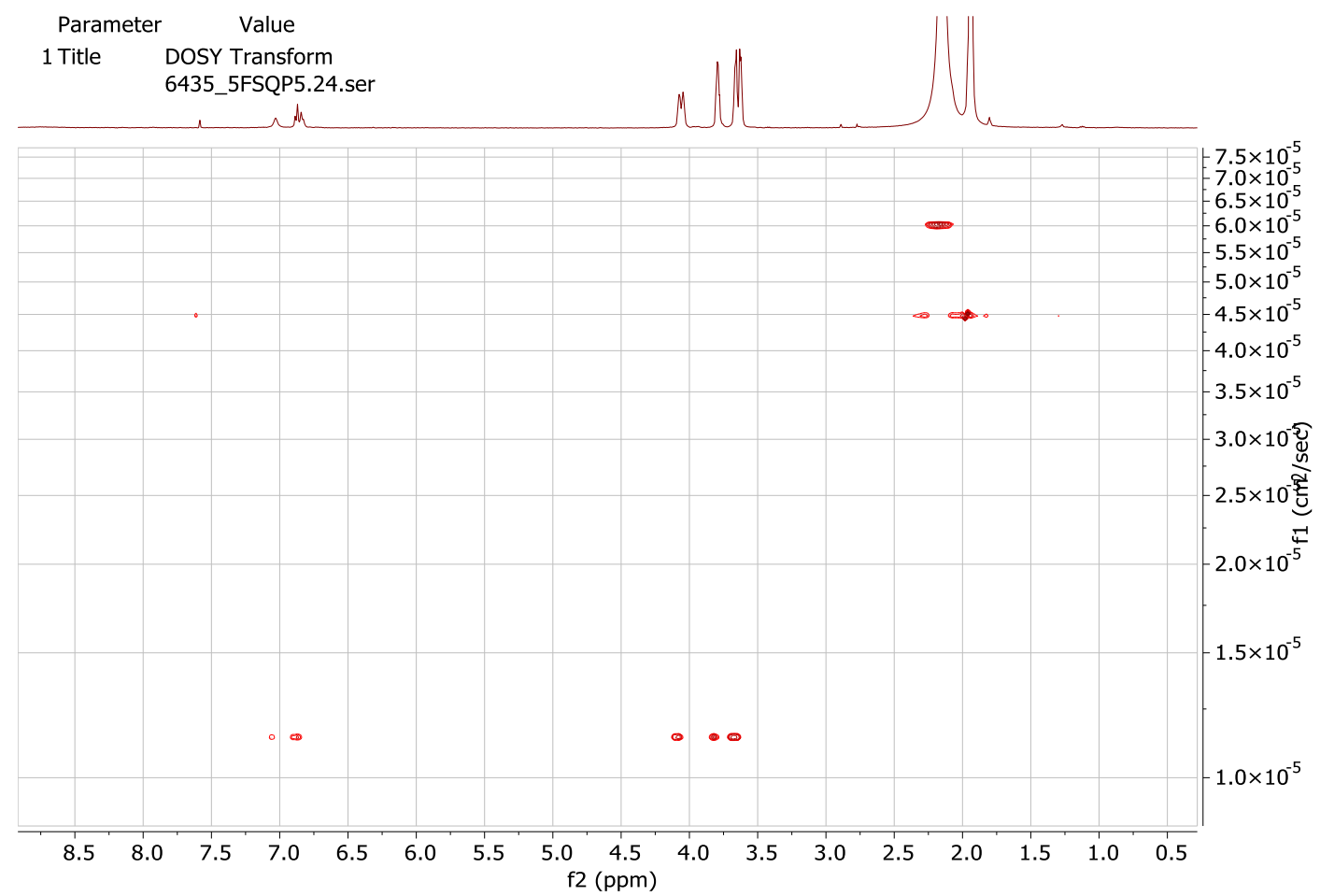

Fig. S71. DOSY NMR spectrum of Receptor $1(1 \mathrm{mM})$ in $\mathrm{CD}_{3} \mathrm{CN}$.

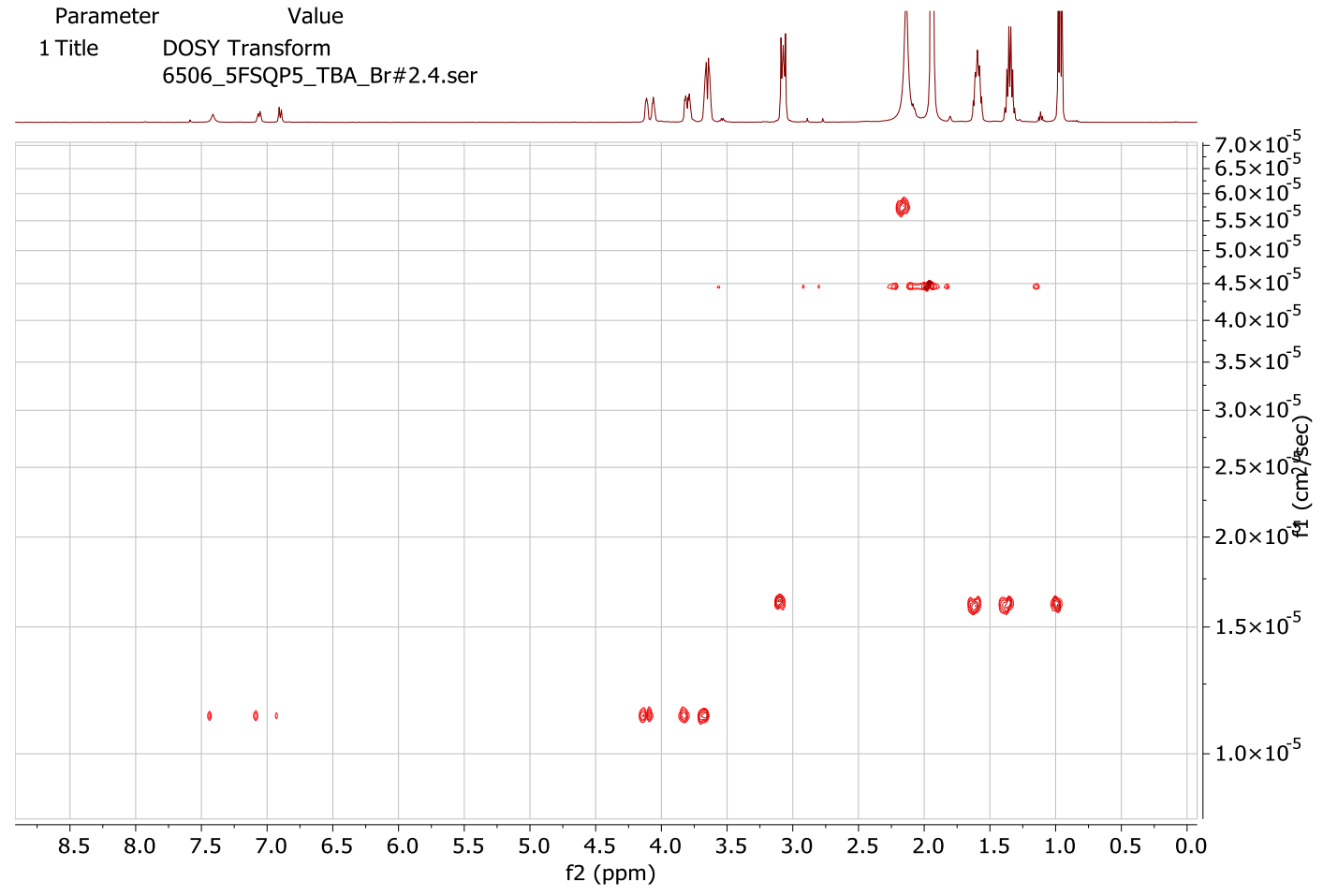

Fig. S72. DOSY NMR spectrum of Receptor $1(1 \mathrm{mM})+1$ eq. TBABr in $\mathrm{CD}_{3} \mathrm{CN}$. 


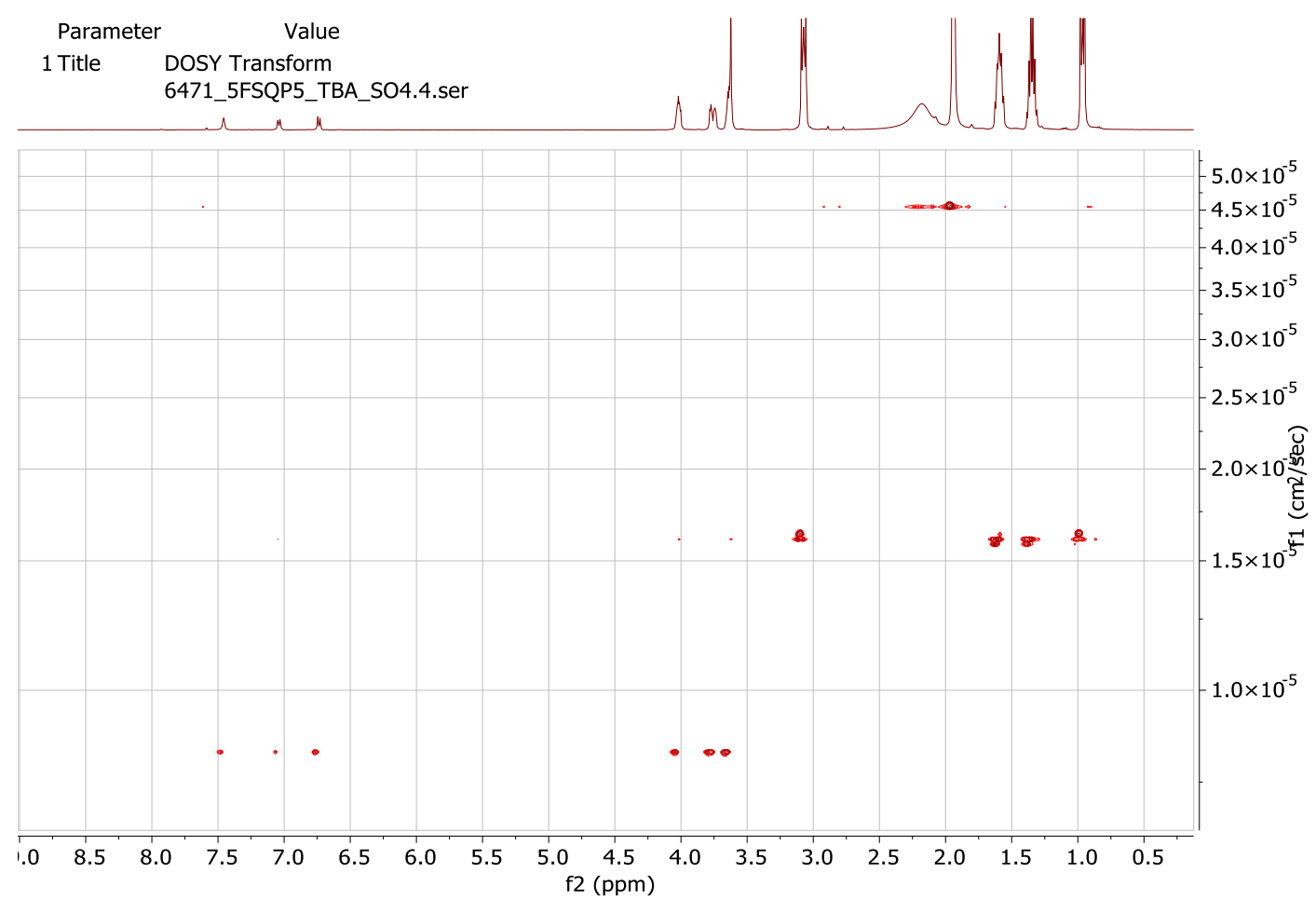

Fig. S73. DOSY NMR spectrum of Receptor $1(1 \mathrm{mM})+1$ eq. $\mathrm{TBA}_{2} \mathrm{SO}_{4}$ in $\mathrm{CD}_{3} \mathrm{CN}$.

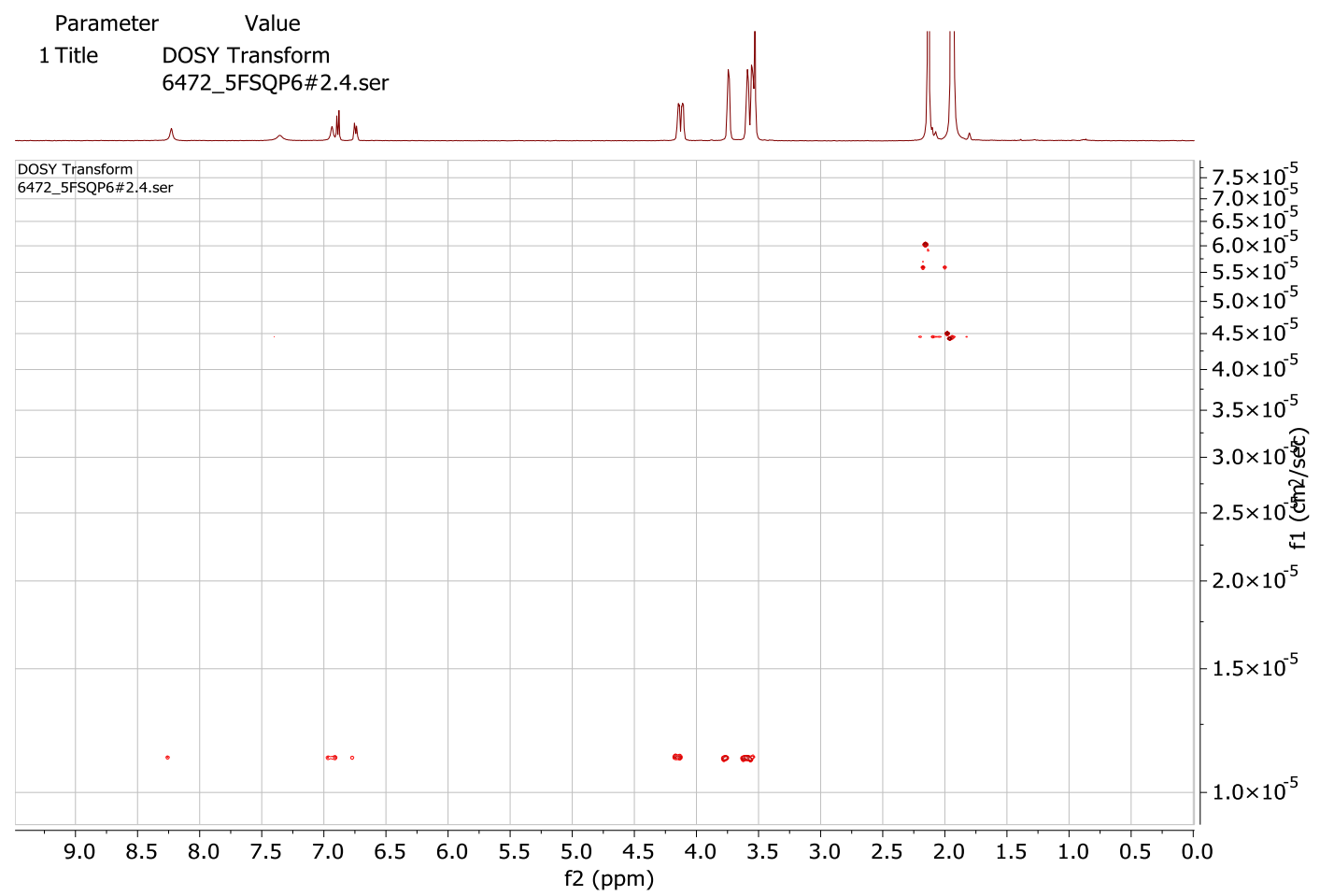

Fig. S74. DOSY NMR spectrum of Receptor $2(1 \mathrm{mM})$ in $\mathrm{CD}_{3} \mathrm{CN}$. 


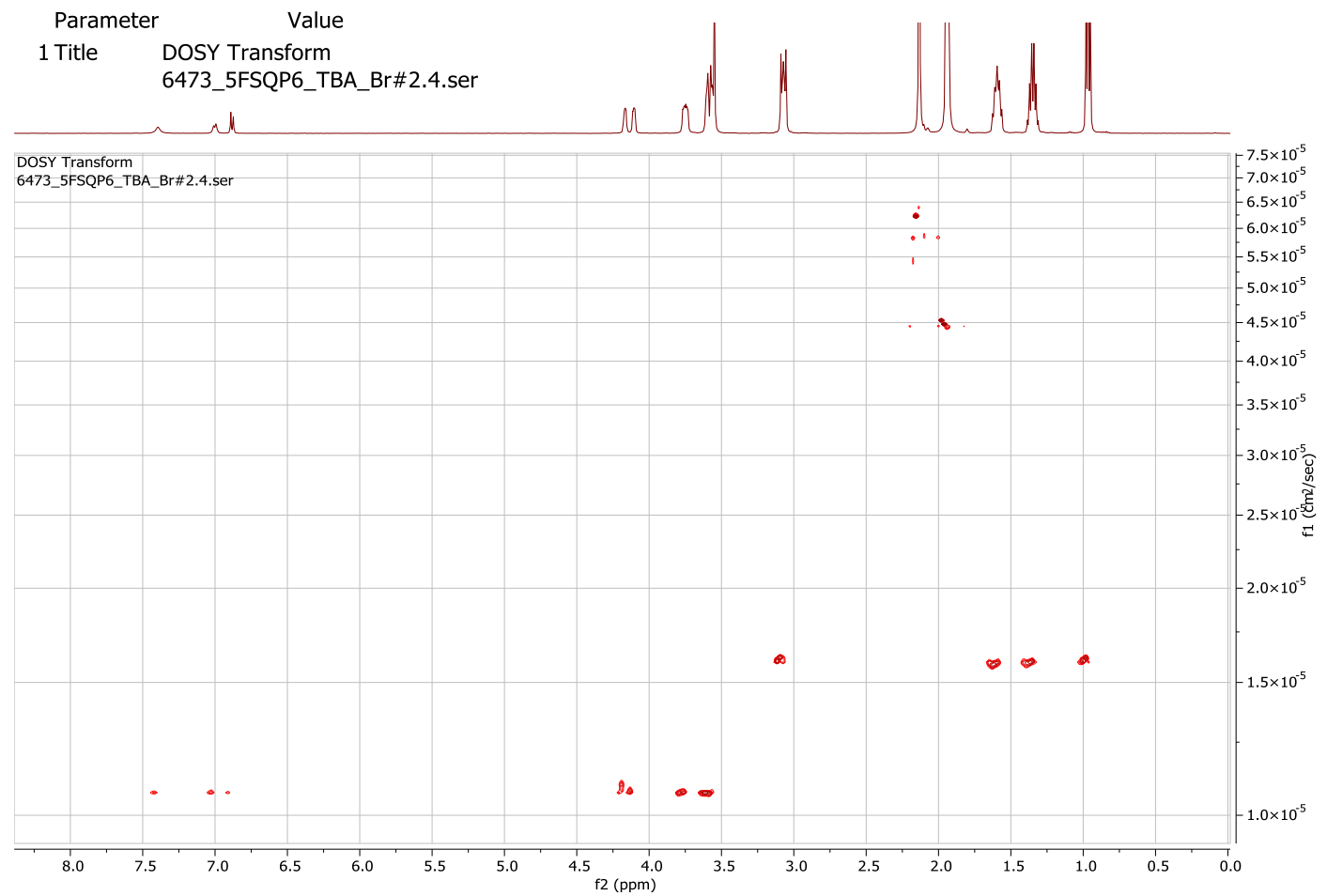

Fig. S75. DOSY NMR spectrum of Receptor $2(1 \mathrm{mM})+1$ eq. TBABr in $\mathrm{CD}_{3} \mathrm{CN}$.

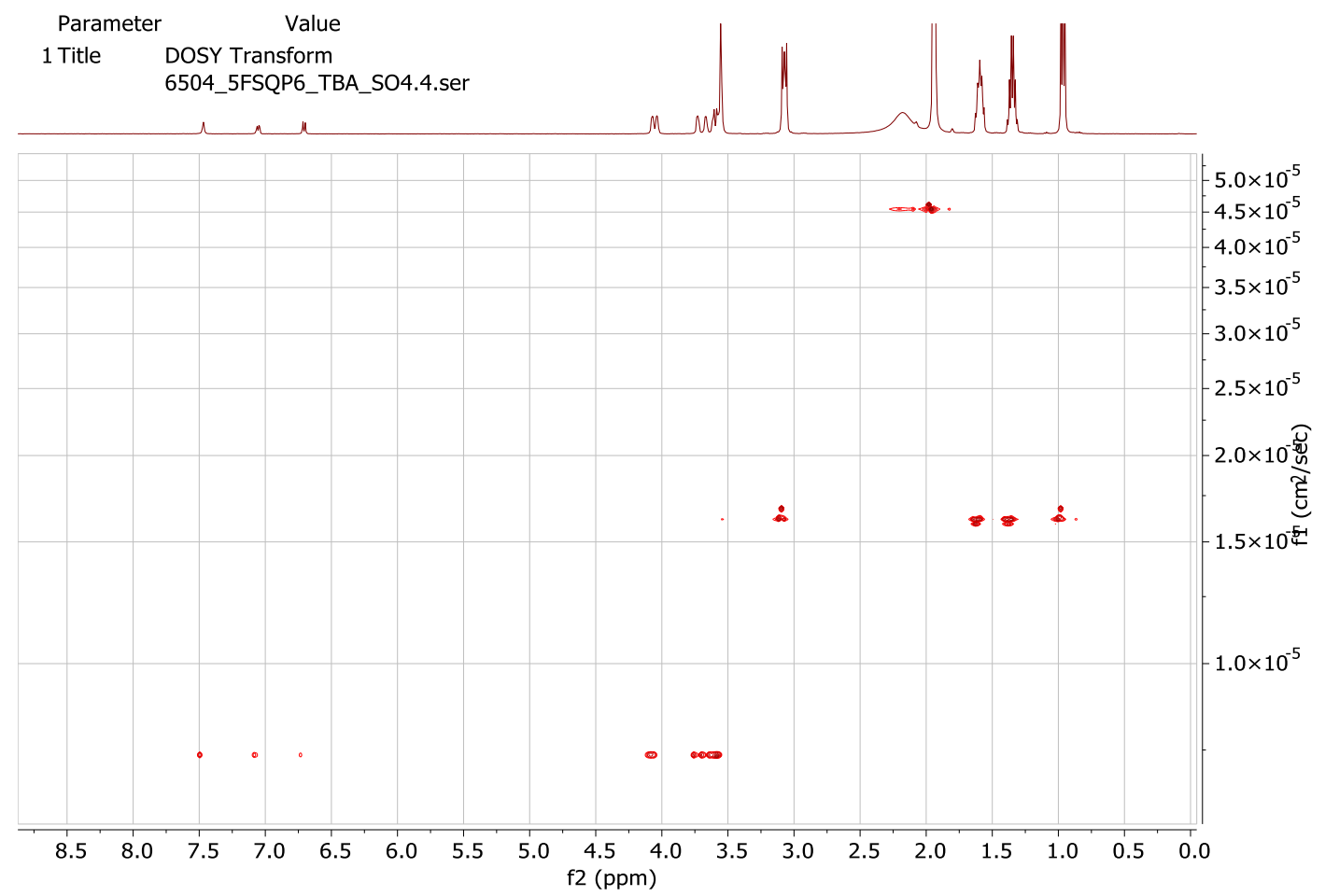

Fig. S76. DOSY NMR spectrum of Receptor $2(1 \mathrm{mM})+1$ eq. $\mathrm{TBA}_{2} \mathrm{SO}_{4}$ in $\mathrm{CD}_{3} \mathrm{CN}$. 


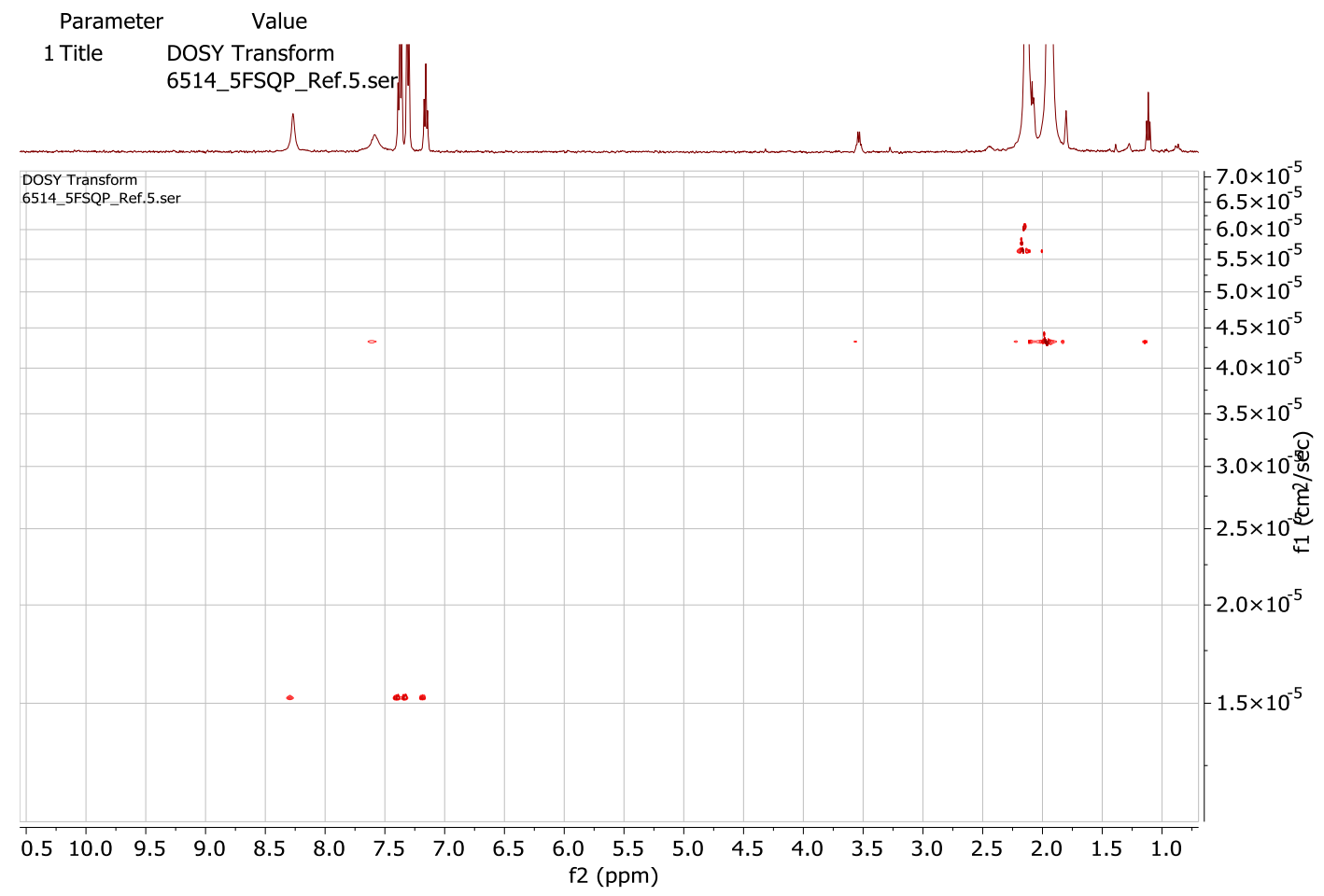

Fig. S77. DOSY NMR spectrum of Receptor $3(1 \mathrm{mM})$ in $\mathrm{CD}_{3} \mathrm{CN}$.

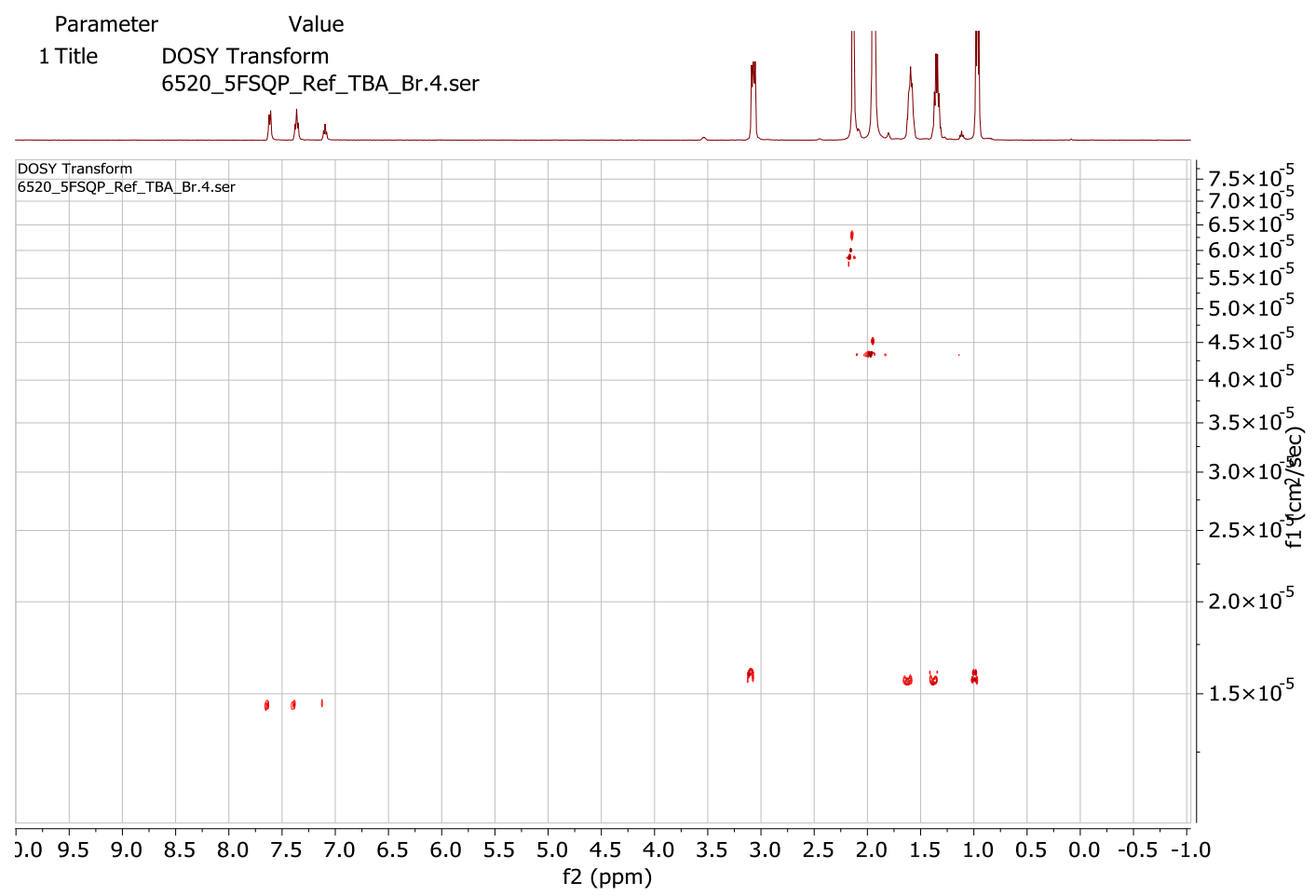

Fig. S78. DOSY NMR spectrum of Receptor $3(1 \mathrm{mM})+1$ eq. $\mathrm{TBABr}$ in $\mathrm{CD}_{3} \mathrm{CN}$. 


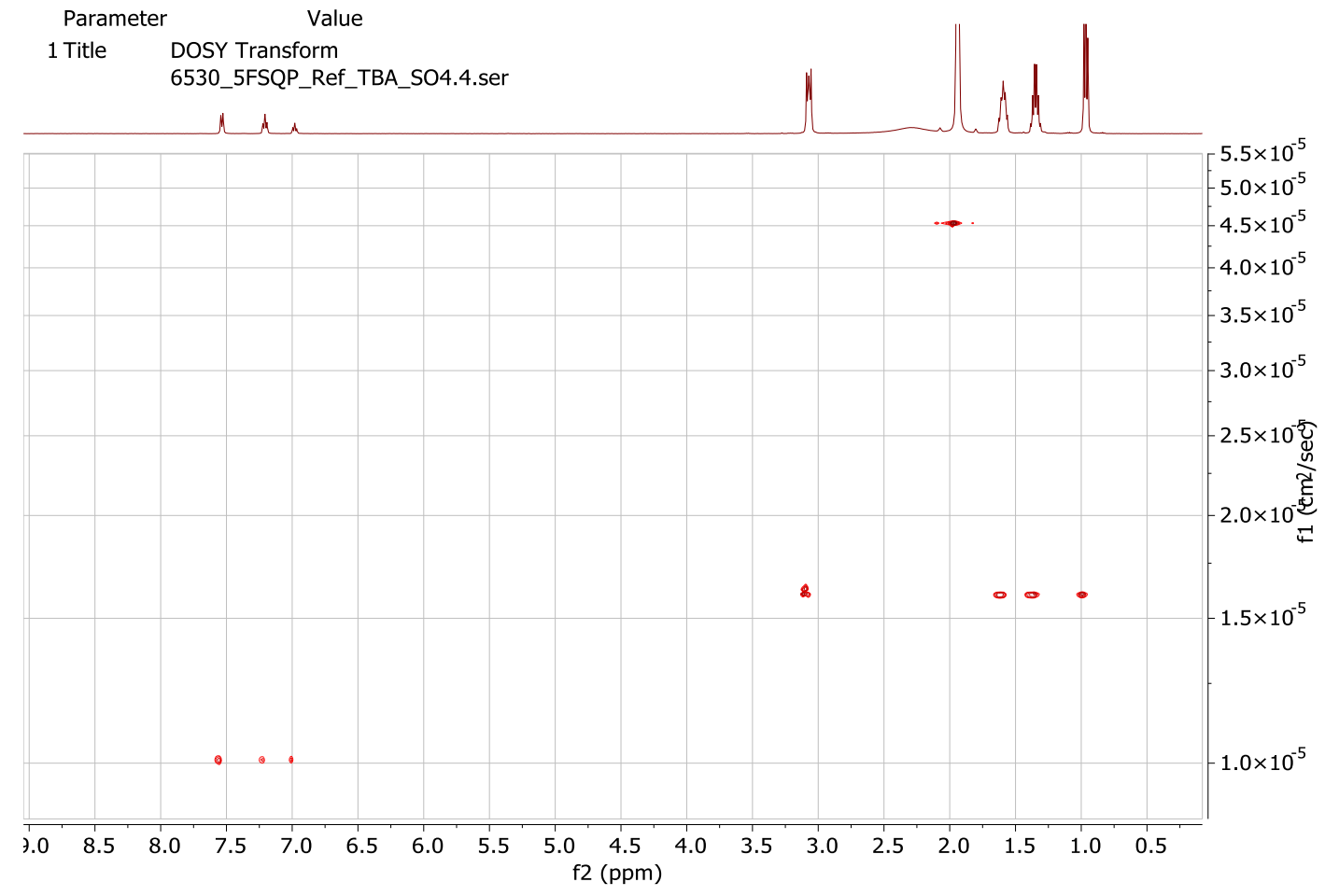

Fig. S79. DOSY NMR spectrum of Receptor $3(1 \mathrm{mM})+1$ eq. $\mathrm{TBA}_{2} \mathrm{SO}_{4}$ in $\mathrm{CD}_{3} \mathrm{CN}$.

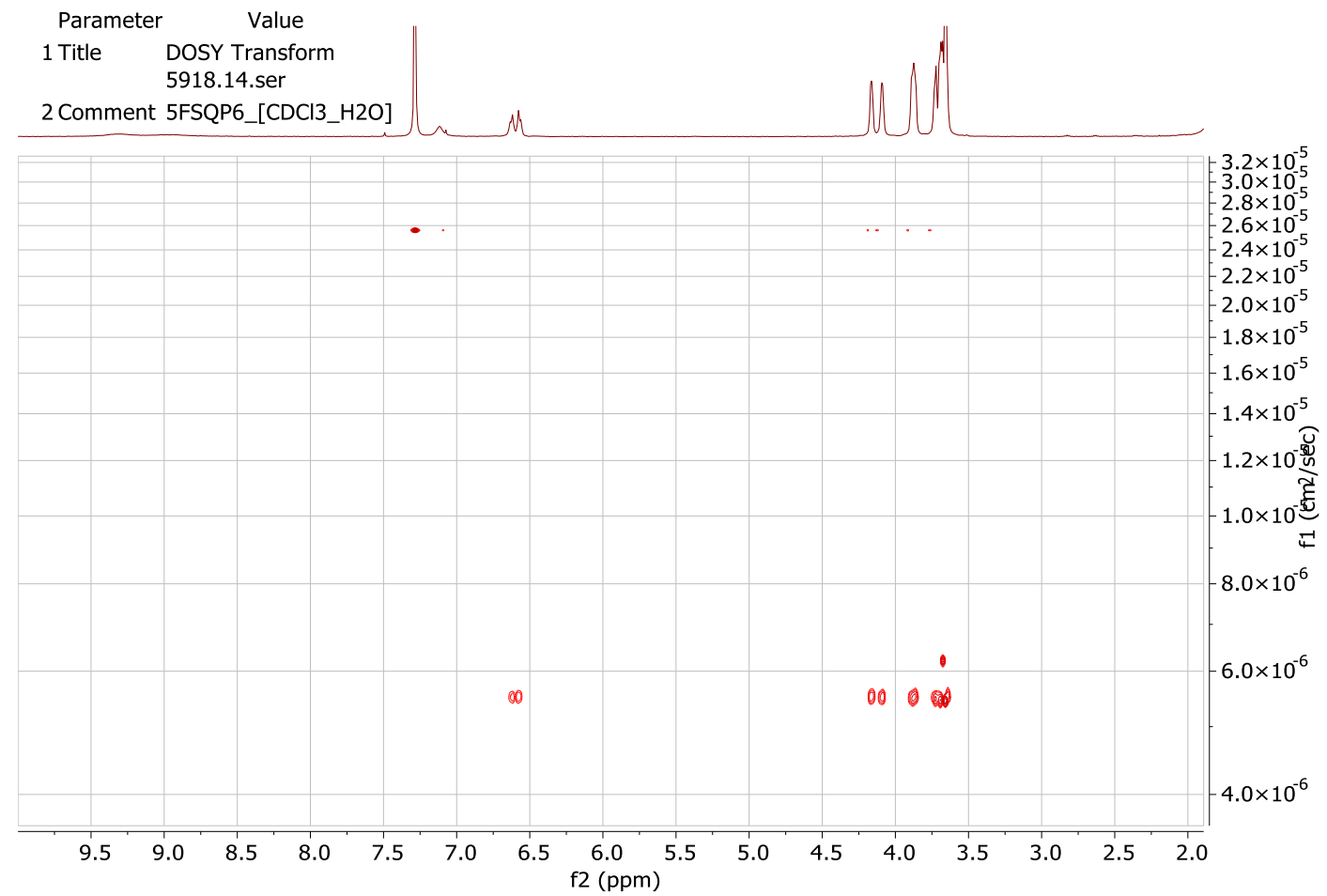

Fig. S80. DOSY NMR spectrum of Receptor $2(1 \mathrm{mM})$ in wet $\mathrm{CDCl}_{3}$. 


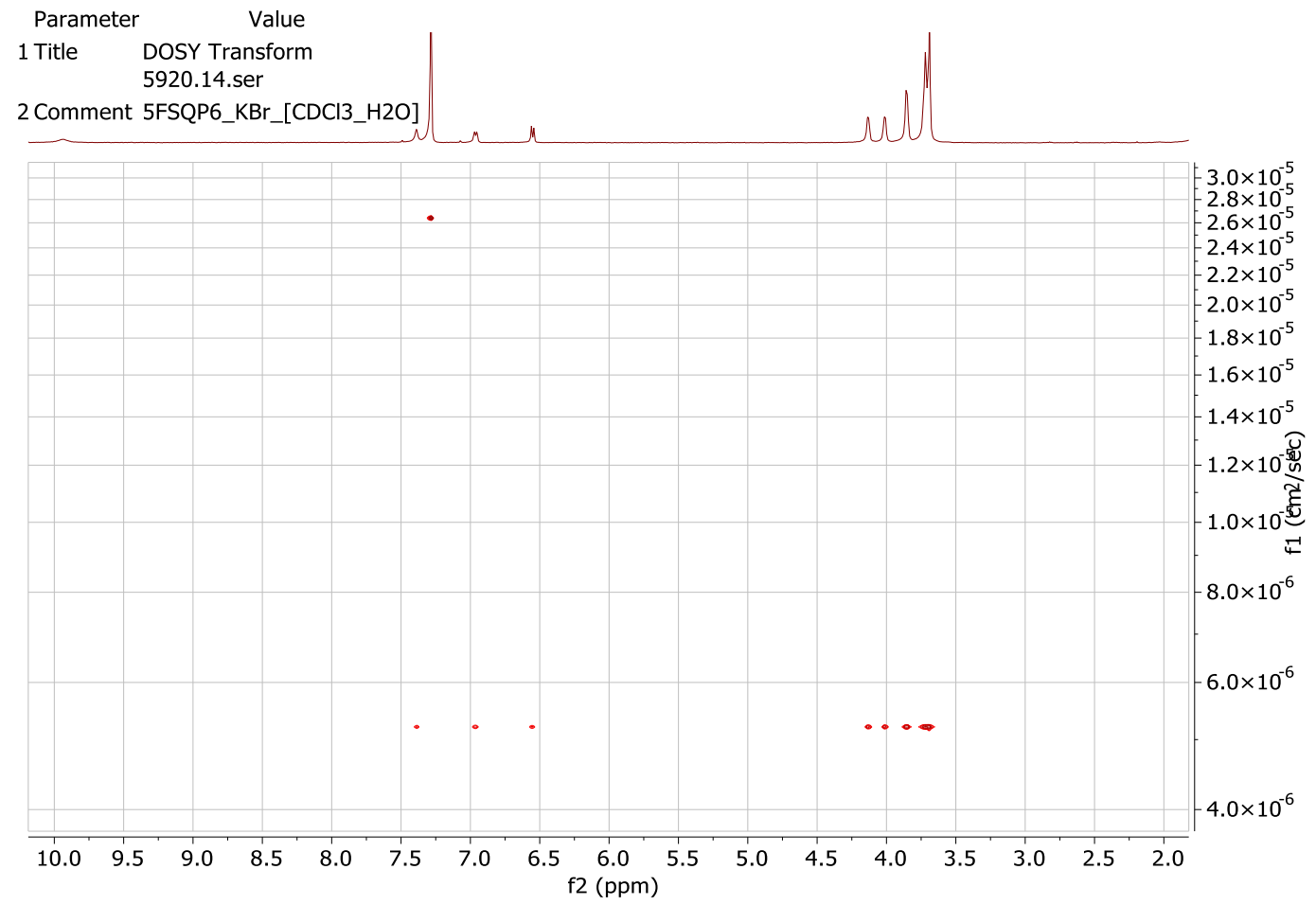

Fig. S81. DOSY NMR spectrum of Receptor $2(1 \mathrm{mM})$ in wet $\mathrm{CDCl}_{3}$ after extraction of aq. solution of $\mathrm{KBr}$.

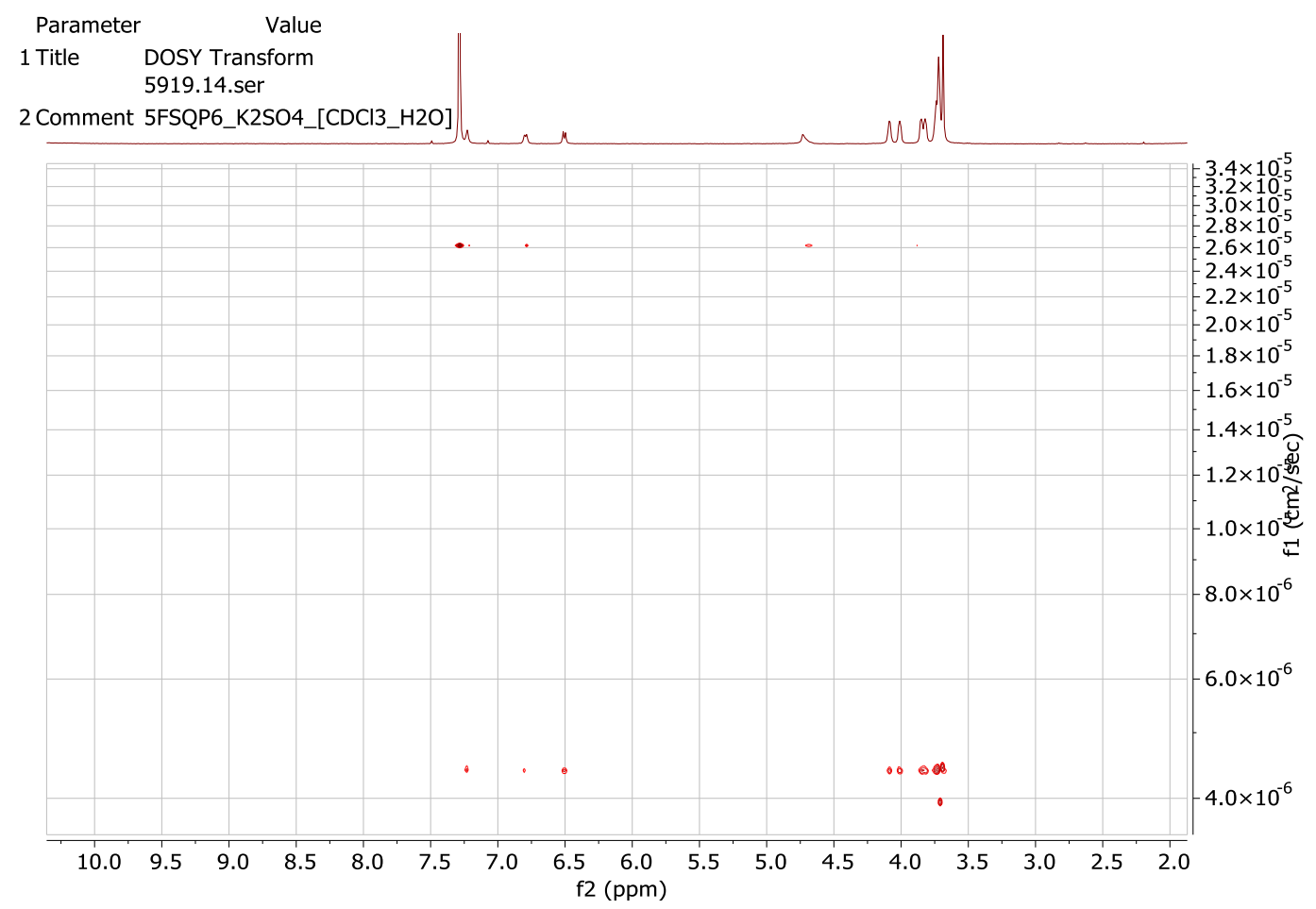

Fig. S82. DOSY NMR spectrum of Receptor $2(1 \mathrm{mM})$ in wet $\mathrm{CDCl}_{3}$ after extraction of aq. solution of $\mathrm{K}_{2} \mathrm{SO}_{4}$. 
U-tube transport studies (Bulk liquid membrane transport experiment)

Source phase and receiving phase: $6 \mathrm{~mL}$. The chloroform phase $(6 \mathrm{~mL})$ was stirred at 1000 rpm during the experiment to ensure efficient diffusion. Salt concentration was measured every day in the receiving phase, and after 7 days the experiment was stopped. The sulfate or chloride concentration was analysed by conductometric method.

Table S2. Cooperative Transport. Source phase $50 \mathrm{mM}\left(\mathrm{TBA}_{2} \mathrm{SO}_{4}\right.$ or $\mathrm{K}_{2} \mathrm{SO}_{4}$ or $\left.\mathrm{KCl}\right)$ in $\mathrm{H}_{2} \mathrm{O}$; Organic phase Receptor $2(5 \mathrm{mM})$ in $\mathrm{CHCl}_{3}$; receiving phase - deionized water.

\begin{tabular}{cccc}
\hline Days & $\mathbf{c}[\mathbf{m M}] \mathbf{~ T B A} \mathbf{S O}_{\mathbf{4}}$ & $\mathbf{c}[\mathbf{m M}] \mathbf{K}_{\mathbf{2}} \mathbf{S O}_{\mathbf{4}}$ & $\mathbf{c}[\mathbf{m M}] \mathbf{~ K C l}$ \\
\hline $\mathbf{1}$ & 0,845 & 0,611 & 2,439 \\
\hline $\mathbf{2}$ & 1,809 & 2,184 & 6,246 \\
\hline $\mathbf{3}$ & 2,622 & 3,735 & 9,176 \\
\hline $\mathbf{4}$ & 3,400 & 5,530 & 11,400 \\
\hline $\mathbf{5}$ & 4,245 & 7,011 & 13,002 \\
\hline $\mathbf{6}$ & 4,910 & 8,261 & 14,347 \\
\hline $\mathbf{7}$ & 5,611 & 9,624 & 15,438 \\
\hline $\mathbf{1 4}$ & - & 15,691 & 19,949 \\
\hline
\end{tabular}

Source phase and receiving phase: $6 \mathrm{~mL}$. The chloroform phase $(6 \mathrm{~mL})$ was stirred at 1000 rpm during the experiment to ensure efficient diffusion. Samples were collected every day from receiving phase, and after 7 days, the experiment was stopped. Ion concentration was analysed by using Ion Chromatography technique.

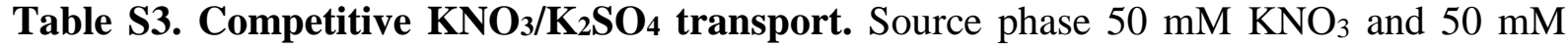
$\mathrm{K}_{2} \mathrm{SO}_{4}$ in $\mathrm{H}_{2} \mathrm{O}$; Organic phase Receptor $2(5 \mathrm{mM})$ in $\mathrm{CHCl}_{3}$; receiving phase - deionized water.

\begin{tabular}{ccc}
\hline Days & $\mathbf{c}[\mathbf{m M}] \mathbf{K N O} \mathbf{N O}_{\mathbf{3}}$ & $\mathbf{c}[\mathbf{m M}] \mathbf{K}_{\mathbf{2}} \mathbf{S O}_{\mathbf{4}}$ \\
\hline $\mathbf{1}$ & 2,681 & 0,580 \\
\hline $\mathbf{2}$ & 5,000 & 2,067 \\
\hline $\mathbf{3}$ & 5,950 & 2,360 \\
\hline $\mathbf{4}$ & 6,350 & 2,540 \\
\hline $\mathbf{5}$ & 7,159 & 2,999 \\
\hline $\mathbf{6}$ & 7,868 & 3,540 \\
\hline $\mathbf{7}$ & 8,196 & 3,897 \\
\hline
\end{tabular}




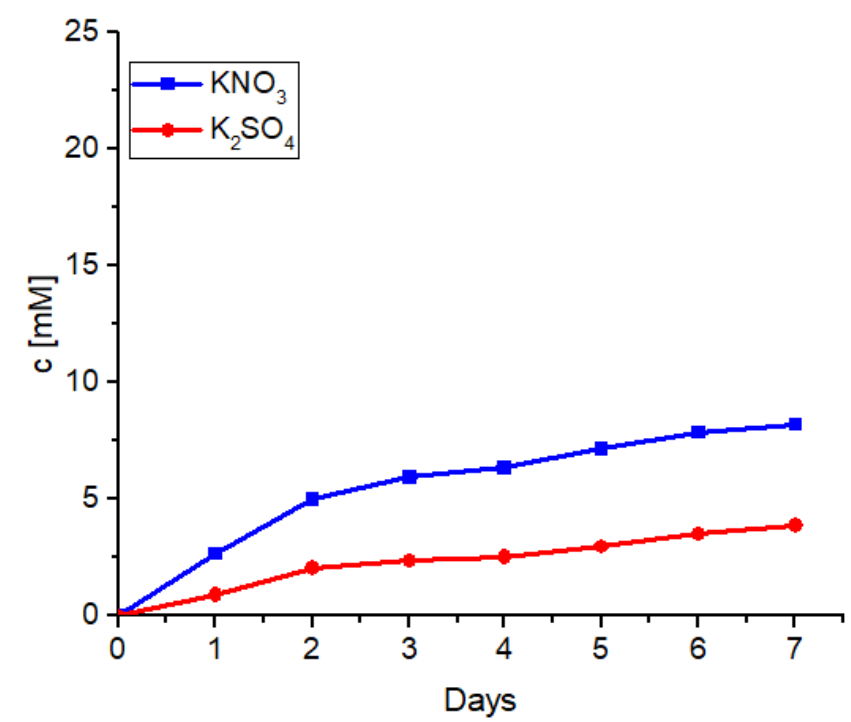

Fig.S83. Competitive $\mathrm{KNO}_{3} / \mathrm{K}_{2} \mathrm{SO}_{4}$ transport by Receptor 2 .

Table S4. Competitive $\mathbf{K C l} / \mathrm{K}_{2} \mathrm{SO}_{4}$ transport. Source phase $50 \mathrm{mM} \mathrm{KCl}$ and $50 \mathrm{mM} \mathrm{K}_{2} \mathrm{SO}_{4}$ in $\mathrm{H}_{2} \mathrm{O}$; Organic phase Receptor $2(5 \mathrm{mM})$ in $\mathrm{CHCl}_{3}$; receiving phase - deionized water.

\begin{tabular}{ccc}
\hline Days & $\mathbf{c}[\mathbf{m M}] \mathbf{K C l}$ & $\mathbf{c}[\mathbf{m M}] \mathbf{K}_{2} \mathbf{S O}_{\mathbf{4}}$ \\
\hline $\mathbf{1}$ & 1,136 & 0,615 \\
\hline $\mathbf{2}$ & 3,059 & 1,869 \\
\hline $\mathbf{3}$ & 3,830 & 2,233 \\
\hline $\mathbf{4}$ & 3,999 & 2,133 \\
\hline $\mathbf{5}$ & 4,811 & 2,721 \\
\hline $\mathbf{6}$ & 5,441 & 3,170 \\
\hline $\mathbf{7}$ & 5,860 & 3,533 \\
\hline
\end{tabular}

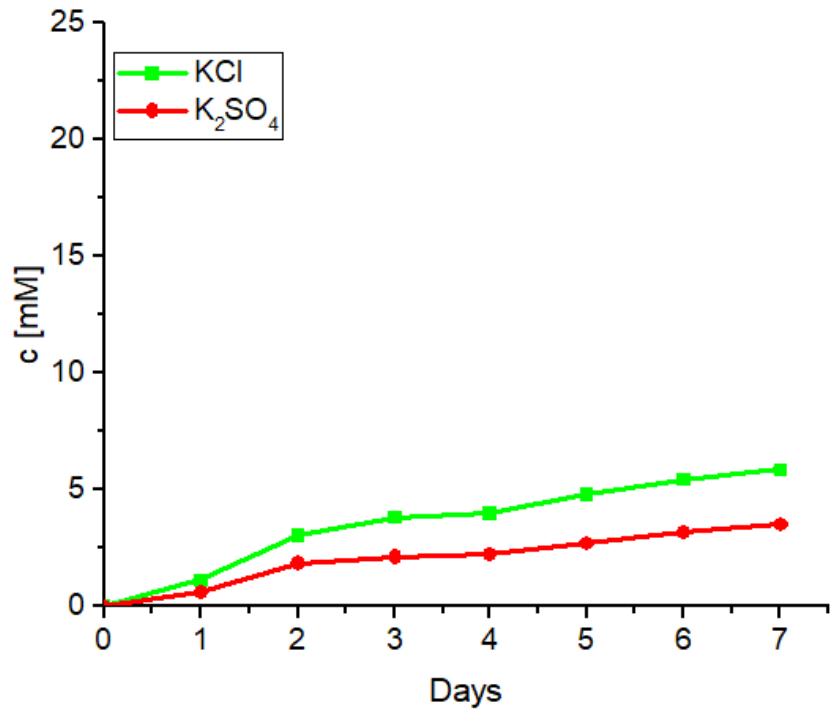

Fig.S84. Competitive $\mathrm{KCl} / \mathrm{K}_{2} \mathrm{SO}_{4}$ transport by Receptor 2. 
Table S5. Supported competitive $\mathrm{KNO}_{3} / \mathrm{K}_{2} \mathrm{SO}_{4}$ transport. Source phase $25 \mathrm{mM} \mathrm{KNO}_{3}$ and $50 \mathrm{mM} \mathrm{K} 2 \mathrm{SO}_{4}$ in $\mathrm{H}_{2} \mathrm{O}$; Organic phase Receptor $2(5 \mathrm{mM})$ in $\mathrm{CHCl}_{3}$; receiving phase $25 \mathrm{mM}$ $\mathrm{KNO}_{3}$ in $\mathrm{H}_{2} \mathrm{O}$.

\begin{tabular}{ccc}
\hline Days & $\mathbf{c}[\mathbf{m M}] \mathbf{K N O 3}$ & $\mathbf{c}[\mathbf{m M}] \mathbf{~ K 2 S O} \mathbf{4}$ \\
\hline $\mathbf{1}$ & 25,001 & 0,555 \\
\hline $\mathbf{2}$ & 24,995 & 1,646 \\
\hline $\mathbf{3}$ & 24,998 & 2,264 \\
\hline $\mathbf{4}$ & 25,000 & 2,870 \\
\hline $\mathbf{5}$ & 25,000 & 3,350 \\
\hline $\mathbf{6}$ & 24,999 & 3,786 \\
\hline $\mathbf{7}$ & 25,000 & 4,304 \\
\hline
\end{tabular}

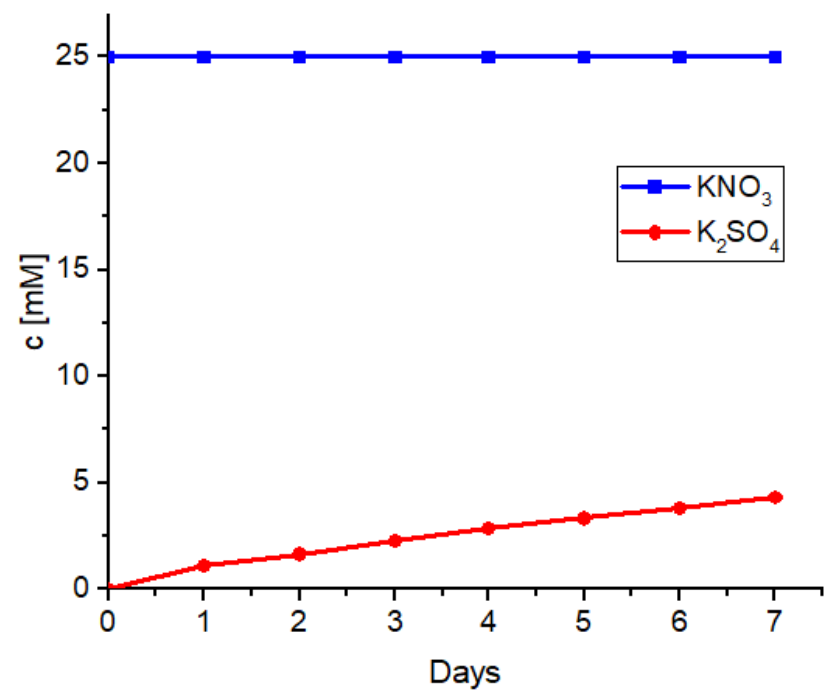

Fig. S85. Supported competitive $\mathrm{KNO}_{3} / \mathrm{K}_{2} \mathrm{SO}_{4}$ transport by Receptor 2.

Table S6. Supported competitive $\mathrm{KCl} / \mathrm{K}_{2} \mathrm{SO}_{4}$ transport. Source phase $25 \mathrm{mM} \mathrm{KCl}$ and $50 \mathrm{mM} \mathrm{K}_{2} \mathrm{SO}_{4}$ in $\mathrm{H}_{2} \mathrm{O}$; Organic phase Receptor $2(5 \mathrm{mM})$ in $\mathrm{CHCl}_{3}$; receiving phase $25 \mathrm{mM}$ $\mathrm{KCl}$ in $\mathrm{H}_{2} \mathrm{O}$.

\begin{tabular}{ccc}
\hline Days & $\mathbf{c}[\mathbf{m M}] \mathbf{K C l}$ & $\mathbf{c}[\mathbf{m M}] \mathbf{K}_{2} \mathbf{S O}_{\mathbf{4}}$ \\
\hline $\mathbf{1}$ & 25,000 & 0,600 \\
\hline $\mathbf{2}$ & 25,001 & 2,320 \\
\hline $\mathbf{3}$ & 25,002 & 3,185 \\
\hline $\mathbf{4}$ & 24,999 & 3,813 \\
\hline $\mathbf{5}$ & 25,000 & 4,420 \\
\hline $\mathbf{6}$ & 25,001 & 4,920 \\
\hline $\mathbf{7}$ & 25,000 & 5,526 \\
\hline
\end{tabular}




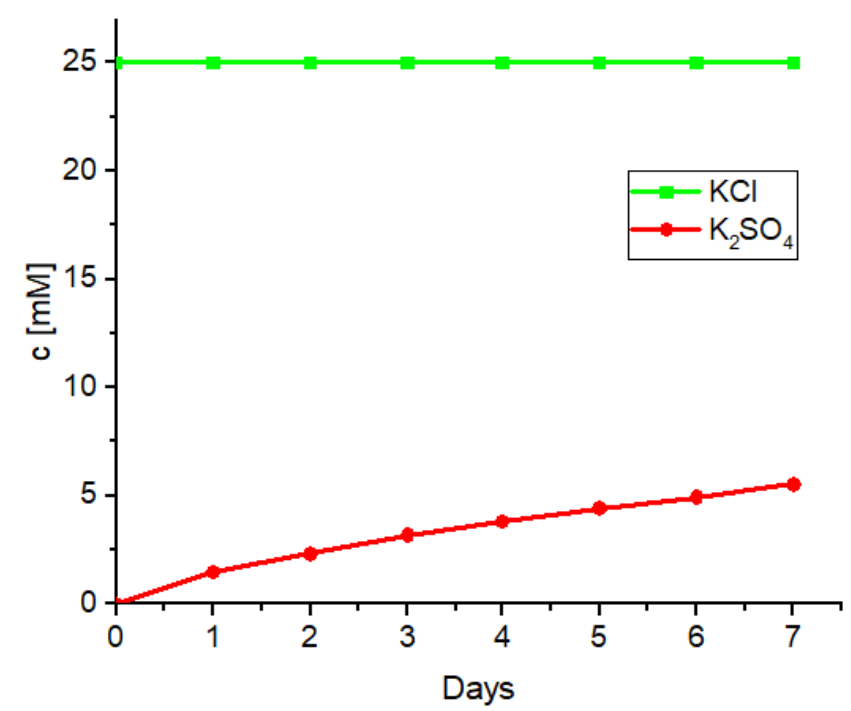

Fig. S86. Supported competitive $\mathrm{KCl} / \mathrm{K}_{2} \mathrm{SO}_{4}$ transport by Receptor 2 .

\section{Crystal data}

The phases suitable for single crystal X-ray diffraction experiment were prepared by slow diffusion of diethyl ether to acetonitrile or acetonitrile/methanol solution containing 2 and appropriate inorganic salt. The samples were measured at lowered temperatures on Bruker D8 Venture single crystal diffractometer equipped with Photon II detector. Data were collected, integrated and scaled with help of Bruker software ${ }^{\text {S1-S3 }}$ and solved and refined in SHELX software package. ${ }^{\text {S4-S6 }}$ Data collection and refinement parameters for the measured samples are grouped in suitable part below together with figures displaying atomic displacement parameters and packing diagrams. These figures were prepared in Mercury 4.1 software. $^{\text {S7 }}$

CCDC1988974-1988976 contains the supplementary crystallographic data for this paper. The data can be obtained free of charge from The Cambridge Crystallographic Data Centre via $\underline{\text { www.ccdc.cam.ac.uk/structures. }}$

Receptor ${ }_{2}+\mathrm{KNO}_{3}$. The $\mathrm{X}$-ray measurement of Receptor $\mathbf{2}_{\mathbf{K N O}}$ was performed at 130.0(5) K on a Bruker D8 Venture PhotonII diffractometer equipped with a INCOATEC I $\mu$ S micro-focus source $(\mathrm{CuK \alpha}, \lambda=1.54178 \AA)$ and a mirror monochromator. A total of 5760 frames 
were collected with Bruker APEX3 program. ${ }^{\text {S2 }}$ The frames were integrated with the Bruker SAINT software package ${ }^{\mathrm{S} 3}$ using a narrow-frame algorithm. The integration of the data using a monoclinic unit cell yielded a total of 42667 reflections to a maximum $\theta$ angle of $66.50^{\circ}(0.84$ $\AA$ resolution), of which 5591 were independent (average redundancy 7.631, completeness = $\left.99.9 \%, R_{\text {int }}=3.80 \%, R_{\text {sig }}=1.74 \%\right)$ and $5166(92.40 \%)$ were greater than $2 \sigma\left(F^{2}\right)$. The final cell constants of $a=19.5699(6) \AA, b=7.9685(3) \AA, c=20.9742(7) \AA, \beta=104.0030(13)^{\circ}, V=$ 3173.58(19) $\AA^{3}$, are based upon the refinement of the XYZ-centroids of 9890 reflections above $20 \sigma(I)$ with $4.653^{\circ}<2 \theta<133.3^{\circ}$. Data were corrected for absorption effects using the MultiScan method (SADABS). ${ }^{\mathrm{S} 4}$ The ratio of minimum to maximum apparent transmission was 0.820. The calculated minimum and maximum transmission coefficients (based on crystal size) are 0.548 and 0.917 .

The structure was solved and refined using SHELXTL Software Package ${ }^{\mathrm{S} 4 \mathrm{~S} 5}$ using the space group $P 2{ }_{1} / c$, with $Z=2$ for the formula unit, $\mathrm{C}_{56} \mathrm{H}_{60} \mathrm{~F}_{10} \mathrm{~K}_{2} \mathrm{~N}_{6} \mathrm{O}_{23}$. The final anisotropic fullmatrix least-squares refinement on $F^{2}$ with 523 variables converged at $R 1=4.82 \%$, for the observed data and $w R 2=14.42 \%$ for all data. The goodness-of-fit was 1.033 . The largest peak in the final difference electron density synthesis was $0.308 \mathrm{e}^{-} / \AA^{3}$ and the largest hole was -0.318 $\mathrm{e}^{-/} \AA^{3}$ with an RMS deviation of $0.052 \mathrm{e}^{-/} \AA^{3}$. On the basis of the final model, the calculated density was $1.521 \mathrm{~g} / \mathrm{cm}^{3}$ and $F(000), 1500 \mathrm{e}^{-}$. Crystal data and refinement parameters for

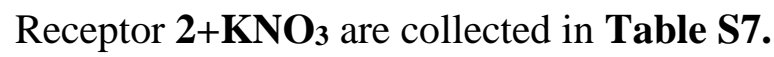

In the ligand the F-substituted phenyl ring is disordered over two positions with refined occupancy ratio yielding 0.816(9):0.184(9). Also $\mathrm{NO}_{3}{ }^{-}$moiety is disordered over two sites with refined occupancy equal 0.931(6):0.069(6). In addition the crystal contains disordered diethyl ether solvent molecule located on centre of symmetry, equally sharing two locations. To model the disorder a number of geometrical restraints was used. Some restrains for atomic displacements in the disordered fragments were also applied. 
All ordered non-hydrogen atoms and major component disordered moieties were refined anisotropically. Most of hydrogen atoms were placed in calculated positions and refined within the riding model. Positions of two hydrogen atoms engaged in intramolecular hydrogen bonds (N-H moieties) were refined. The temperature factors of hydrogen atoms were not refined (except the atoms engaged in hydrogen bonds) and were set to be1.2 times larger than $U_{e q}$ of the corresponding heavy atom. The atomic scattering factors were taken from the International Tables. ${ }^{56}$ Molecular graphics was prepared using program Mercury 4.1. ${ }^{\mathrm{S}}$ Atomic displacement parameters are presented in Fig. S87 a) at 50\% probability level, packing diagrams are shown in Fig. S 88 a).

Receptor $2+\mathbf{K C l} / \mathbf{N a C l}$. The $\mathrm{X}$-ray measurement of Receptor $2+\mathbf{K C l} / \mathbf{N a C l}$ was performed at 100.0(5) $\mathrm{K}$ on a Bruker D8 Venture PhotonII diffractometer equipped with a TRIUMPH monochromator and a MoKa fine focus sealed tube $(\lambda=0.71073 \AA)$. A total of 3794 frames were collected with Bruker APEX3 program. ${ }^{\mathrm{S} 1}$ The frames were integrated with the Bruker SAINT software package ${ }^{\mathrm{S} 2}$ using a narrow-frame algorithm. The integration of the data using a monoclinic unit cell yielded a total of 30223 reflections to a maximum $\theta$ angle of $66.54^{\circ}(0.84$ $\AA$ resolution), of which 4996 were independent (average redundancy 6.049, completeness = $\left.99.8 \%, R_{\text {int }}=3.23 \%, R_{\text {sig }}=1.93 \%\right)$ and $4685(93.78 \%)$ were greater than $2 \sigma\left(F^{2}\right)$. The final cell constants of $a=18.1253(5) \AA, b=7.8928(2) \AA, c=19.8048(5) \AA, \beta=90.0610(12)^{\circ}, V=$ 2833.26(13) $\AA^{3}$, are based upon the refinement of the XYZ-centroids of 9802 reflections above $20 \sigma(I)$ with $4.875^{\circ}<2 \theta<136.5^{\circ}$. Data were corrected for absorption effects using the MultiScan method (SADABS). ${ }^{\mathrm{S} 3}$ The ratio of minimum to maximum apparent transmission was 0.807. The calculated minimum and maximum transmission coefficients (based on crystal size) are 0.483 and 0.934 .

The structure was solved and refined using SHELXTL Software Package ${ }^{\mathrm{S} 4, \mathrm{~S} 5}$ using the space group $P 2_{1} / c$, with $Z=2$ for the formula unit, $\mathrm{C}_{52} \mathrm{H}_{50} \mathrm{Cl}_{2} \mathrm{~F}_{10} \mathrm{~K}_{1.31} \mathrm{~N}_{4} \mathrm{Na}_{0.69} \mathrm{O}_{16}$. The final 
anisotropic full-matrix least-squares refinement on $F^{2}$ with 455 variables converged at $R 1=$ $3.63 \%$, for the observed data and $w R 2=9.44 \%$ for all data. The goodness-of-fit was 1.032 . The largest peak in the final difference electron density synthesis was $0.284 \mathrm{e}^{-} / \AA^{3}$ and the largest hole was $-0.208 \mathrm{e}^{-} / \AA^{3}$ with an RMS deviation of $0.042 \mathrm{e}^{-} / \AA^{3}$. On the basis of the final model, the calculated density was $1.541 \mathrm{~g} / \mathrm{cm}^{3}$ and $F(000), 1349 \mathrm{e}^{-}$. Crystal data and refinement parameters for Receptor $\mathbf{2 + K C l / N a C l}$ are collected in Table S7.

In the structure the crown ether fragment is disordered over three sites with refined occupancy ratio equal to $0.655(2): 0.142(3): 0.203(3)$. In addition the structure contains the mixed $\mathrm{Na}^{+} / \mathrm{K}^{+}$ sites of the cation coordinated by the crown ether moiety. The refined occupancy of $\mathrm{Na}^{+} / \mathrm{K}^{+}$ ions yields $0.655(2): 0.345(2)$. Due to the presence of different size ions in the crown ether moiety the metal-site coordinating carbonyl group of the squaramide unit is also disordered over two position with the same occupancy ratio as refined for $\mathrm{Na}^{+} / \mathrm{K}^{+}$ions. This substitutional disorder results in non-integer atom count in the unit cell. All major component non-hydrogen atoms were refined anisotropically. Most of hydrogen atoms were placed in calculated positions and refined within the riding model. Positions of two hydrogen atoms engaged in hydrogen bonds were refined, together with their temperature factors. Temperature factors of all other hydrogen atoms were not refined and were set to be 1.2 times larger than $U_{e q}$ of the corresponding heavy atom. The atomic scattering factors were taken from the International Tables. ${ }^{\mathrm{S} 6}$ Molecular graphics was prepared using program Mercury 4.1. ${ }^{\mathrm{S} 7}$ Atomic displacement parameters are presented in Fig. S87 b) at 50\% probability level, packing diagrams are shown in Fig. S88 b).

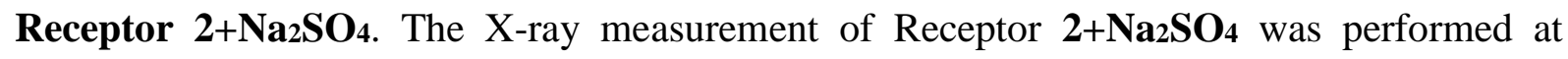
100.0(5) K on a Bruker D8 Venture PhotonII diffractometer equipped with a TRIUMPH monochromator and a MoKa fine focus sealed tube $(\lambda=0.71073 \AA)$. A total of 2400 frames were collected with Bruker APEX3 program. ${ }^{\mathrm{S} 1}$ The frames were integrated with the Bruker 
SAINT software package ${ }^{\mathrm{S} 3}$ using a narrow-frame algorithm. The integration of the data using a monoclinic unit cell yielded a total of 119249 reflections to a maximum $\theta$ angle of $25.05^{\circ}$ (0.84 $\AA$ resolution), of which 11108 were independent (average redundancy 10.735, completeness $\left.=99.9 \%, R_{\text {int }}=3.64 \%, R_{\text {sig }}=1.82 \%\right)$ and $9555(86.02 \%)$ were greater than $2 \sigma\left(F^{2}\right)$. The final cell constants of $a=12.0787(9) \AA, b=43.414(3) \AA, c=23.9907(18) \AA, \beta=$ 95.624(3) $)^{\circ}, V=12519.8(16) \AA^{3}$, are based upon the refinement of the XYZ-centroids of 9837 reflections above $20 \sigma(I)$ with $4.662^{\circ}<2 \theta<50.76^{\circ}$. Data were corrected for absorption effects using the Multi-Scan method (SADABS). ${ }^{\text {S3 }}$ The ratio of minimum to maximum apparent transmission was 0.898 . The calculated minimum and maximum transmission coefficients (based on crystal size) are 0.949 and 0.978 .

The structure was solved and refined using SHELXTL Software Package ${ }^{\mathrm{S} 4, \mathrm{~S} 5}$ using the space group $C 2 / c$, with $\mathrm{Z}=1$ for the formula unit, $\mathrm{C}_{457.20} \mathrm{H}_{460} \mathrm{~F}_{80} \mathrm{~N}_{52} \mathrm{Na}_{8} \mathrm{O}_{147.20} \mathrm{~S}_{4}$. The final anisotropic full-matrix least-squares refinement on $F^{2}$ with 933 variables converged at $R 1=4.84 \%$, for the observed data and $w R 2=10.99 \%$ for all data. The goodness-of-fit was 1.099 . The largest peak in the final difference electron density synthesis was $0.721 \mathrm{e}^{-} / \AA^{3}$ and the largest hole was -0.302 $\mathrm{e}^{-} / \AA^{3}$ with an RMS deviation of $0.046 \mathrm{e}^{-} / \AA^{3}$. On the basis of the final model, the calculated density was $1.442 \mathrm{~g} / \mathrm{cm}^{3}$ and $F(000), 5617 \mathrm{e}^{-}$. Crystal data and refinement parameters for Receptor $2+\mathrm{Na}_{2} \mathrm{SO}_{4}$ are collected in Table S7.

The structure in the asymmetric part contains one fully ordered ligand molecule; another ligand with $\mathrm{Na}^{+}$cation located in disordered over three positions crown ether fragment and coordinated by two acetonitrille molecules; halve of disordered over two sites $\mathrm{SO}_{4}{ }^{2-}$ moiety located on 2fold axis of symmetry. In the structure there are also disordered acetonitrille, water and methanol molecules all located on 2-fold axis of symmetry. The later one is disordered over four sites with the overall site occupancy equal to 0.3 , whereas the total site occupancy of disorder water molecule is 0.5 , this results in non-integer count of the $\mathrm{C}$ and $\mathrm{O}$ atoms in the unit 
cell. Both methanol and water molecules have no hydrogen atoms assigned. The methyl group of one of acetonitrile molecule coordinating $\mathrm{Na}$ moiety is disordered over two sites with equal occupancies. The refined occupancy of the disordered crown ether fragment yields 0.369(3):0.415(3):0.216(3). Short Inter D...A Contact between O8B and O1V atoms indicated as Alert level B in the check CIF report corresponds to hydrogen bond between disordered water molecule and carbonyl group of the squaramide unit.

All major component non- $\mathrm{H}$ atoms of at least 0.5 occupancy were refined anisotropically. Most of hydrogen atoms were placed in calculated positions and refined within the riding model. Positions of four hydrogen atoms engaged in hydrogen bonds were refined, together with their temperature factors. Temperature factors of all other hydrogen atoms were not refined and were set to be either 1.2 or 1.5 times larger than $U_{e q}$ of the corresponding heavy atom. The atomic scattering factors were taken from the International Tables. ${ }^{\mathrm{S} 6}$ Molecular graphics was prepared using program Mercury 4.1. ${ }^{\mathrm{S} 7}$ Thermal ellipsoids parameters are presented at $50 \%$ probability level. Atomic displacement parameters are presented in Fig. S87 c) at 50\% probability level, packing diagrams are shown in Fig. S88 c).

During structure refinement of all discussed crystals the same numbering scheme of the atoms in 2, presented in Scheme $\mathbf{S 2}$, was used.

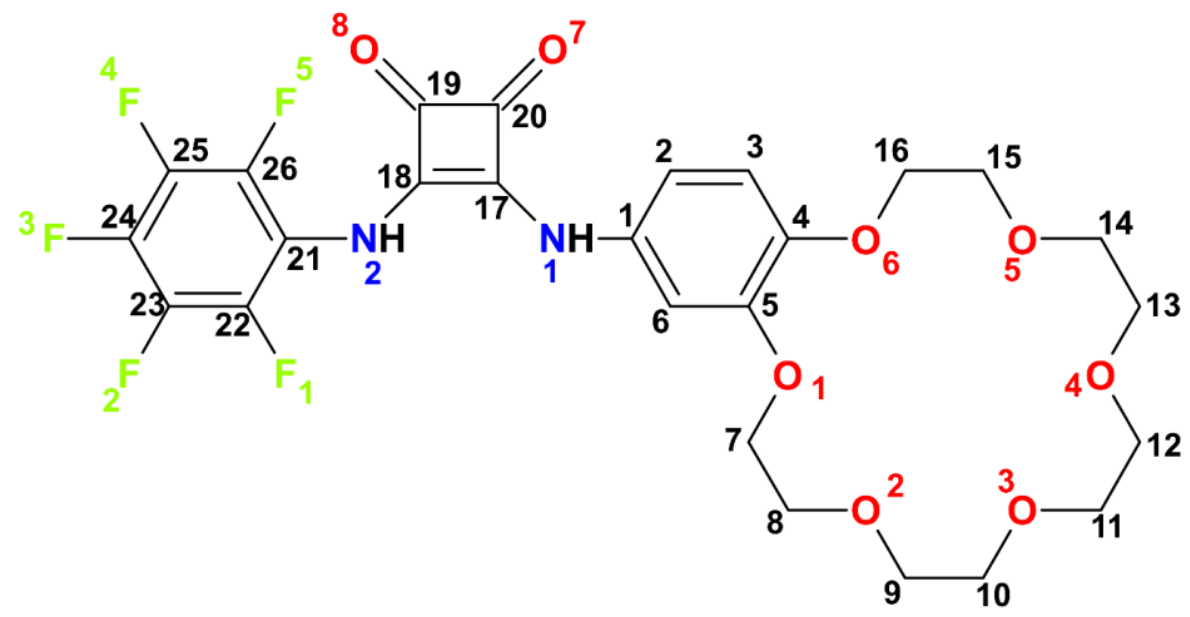

Scheme S2. Numbering scheme of the heavy atoms in the ligand used during structure refinements. 
Table S7. Crystal.

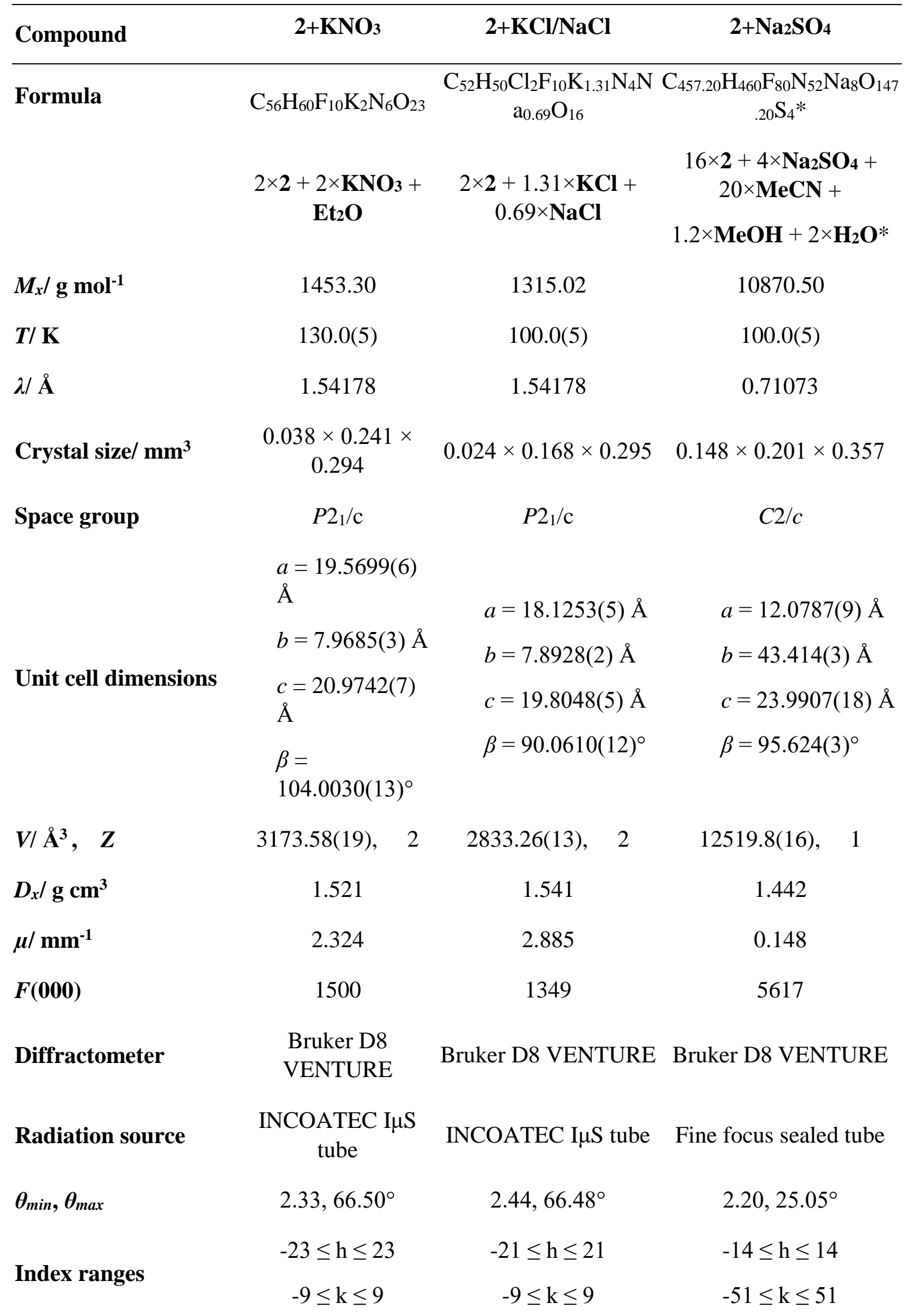




$$
-24 \leq 1 \leq 24 \quad-23 \leq 1 \leq 22 \quad-28 \leq 1 \leq 28
$$

Reflections collected/

independent

Completeness

Absorption

correction

$T_{\max }, T_{\min }$

Refinement method

Data / restraints / parameters

GooF on $F^{2}$

Final $\mathbf{R}$ indices

$42667 / 5591\left(R_{i n t}=\right.$

$0.0380)$

$99.9 \%$

Multi-Scan

0.917. 0.548

Full-matrix LSQ on $F^{2}$

$5591 / 132 / 523$

1.033

1.032

1.099

5166 data; $I>2 \sigma(I) \quad 4685$ data; $I>2 \sigma(I) \quad 9555$ data; $I>2 \sigma(I)$

$R 1=0.0482, w R 2=R 1=0.0363, w R 2=R 1=0.0484, w R 2=$

0.1410

0.0930

0.1047

all data all data all data

$R 1=0.0506, w R 2=R 1=0.0384, w R 2=R 1=0.0576, w R 2=$

$0.1442 \quad 0.0944 \quad 0.1099$

Extinction coefficient

$\Delta \rho_{\max }, \Delta \rho_{\min }$

$0.308,-0.318 \mathrm{e}^{-3}$

$0.284,-0.208$ e $\AA^{-3}$

$0.00026(3)$

*Hydrogen atoms of partial occupancy disordered water and methanol moieties not assigned. 


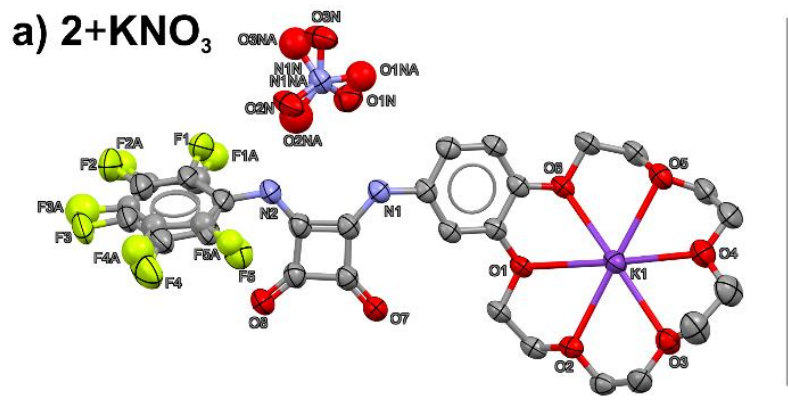

b) $2+\mathrm{KCl} / \mathrm{NaCl}$

c) $2+\mathrm{Na}_{2} \mathrm{SO}_{4}$
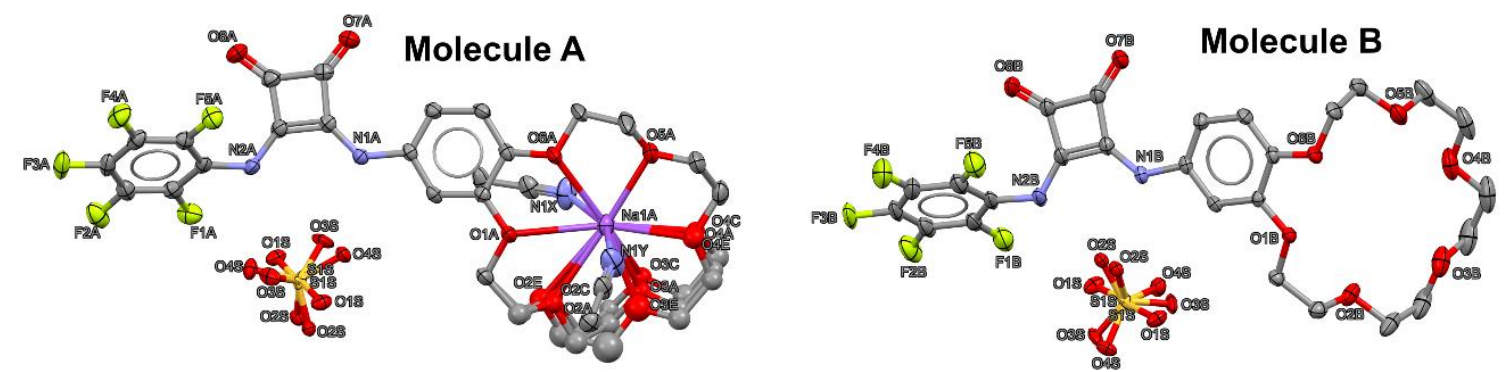

Fig. S87. Numbering scheme of all non-C atoms and atomic displacement parameters presented at $50 \%$ probability level for structure Receptor $\mathbf{2}+\mathrm{KNO}_{3}$ a); Receptor $2+\mathrm{KCl} / \mathbf{N a C l}$ b) and Receptor $2+\mathrm{Na}_{2} \mathrm{SO}_{4} \mathrm{c}$ ). All hydrogen atoms and notcoordinating solvent molecules omitted for clarity. For the structure Receptor 2+Na2SO4 molecules A and B displayed separately.

a) $2+\mathrm{KNO}_{3}$

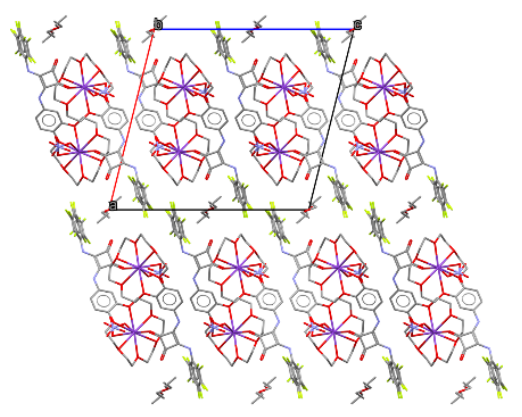

b) $2+\mathrm{KCl} / \mathrm{NaCl}$

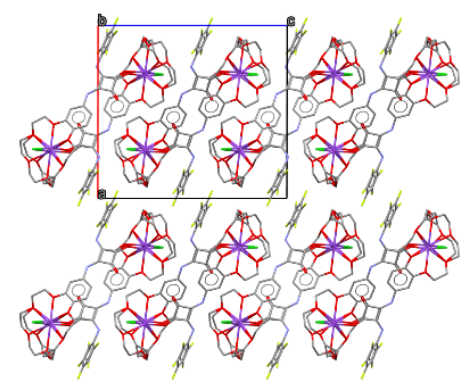

c) $2+\mathrm{Na}_{2} \mathrm{SO}_{4}$

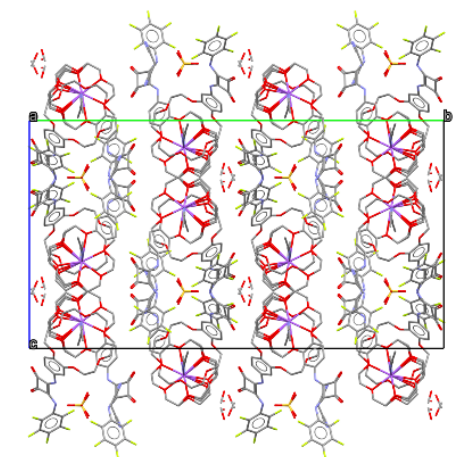

Fig. S88. Packing diagrams of structure Receptor $\mathbf{2}+\mathrm{KNO}_{3}$ along [010] a); Receptor

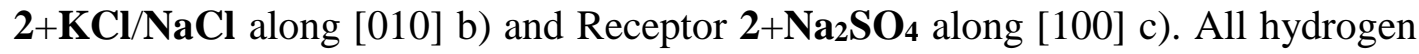
atoms omitted for clarity. 


\section{References}

[S1] APEX3 V2019, Bruker Nano, Inc., 2019.

[S2] SAINT V8.40A, Bruker Nano, Inc., 2019.

[S3] SADABS V2016/2, Bruker Nano, Inc., 2019.

[S4] G. M. Sheldrick. SHELXT-Integrated Space-Group and Crystal-Structure Determination. Acta Cryst., 2015, A71, 3-8.

[S5] G. M. Sheldrick. Crystal Structure Refinement with SHELXL. Acta Cryst., 2015, $C 71,3-8$.

[S6] International Tables for Crystallography, Ed. A. J. C. Wilson, Kluwer: Dordrecht, 1992, Vol.C.

[S7] C. F. Macrae, I. J. Bruno, J. A. Chisholm, P. R. Edgington, P. McCabe, E. Pidcock, L. Rodriguez-Monge, R. Taylor, J. Streek, P. A. Wood. Mercury CSD 2.0 - New Features for the Visualization and Investigation of Crystal Structures. J. Appl. Cryst., 2008, $41,466-470$. 